\title{
Deep Residential Retrofits in East Tennessee
}

\section{April 2012}

Prepared by

Philip Boudreaux Timothy Hendrick Jeff Christian Roderick Jackson 


\section{DOCUMENT AVAILABILITY}

Reports produced after January 1,1996, are generally available free via the U.S. Department of Energy (DOE) Information Bridge.

Web site http://www.osti.gov/bridge

Reports produced before January 1, 1996, may be purchased by members of the public from the following source.

National Technical Information Service

5285 Port Royal Road

Springfield, VA 22161

Telephone 703-605-6000 (1-800-553-6847)

TDD 703-487-4639

Fax 703-605-6900

E-mail info@ntis.gov

Web site http://www.ntis.gov/support/ordernowabout.htm

Reports are available to DOE employees, DOE contractors, Energy Technology Data Exchange (ETDE) representatives, and International Nuclear Information System (INIS) representatives from the following source.

Office of Scientific and Technical Information

P.O. Box 62

Oak Ridge, TN 37831

Telephone 865-576-8401

Fax 865-576-5728

E-mail reports@osti.gov

Web site http://www.osti.gov/contact.html

This report was prepared as an account of work sponsored by an agency of the United States Government. Neither the United States Government nor any agency thereof, nor any of their employees, makes any warranty, express or implied, or assumes any legal liability or responsibility for the accuracy, completeness, or usefulness of any information, apparatus, product, or process disclosed, or represents that its use would not infringe privately owned rights. Reference herein to any specific commercial product, process, or service by trade name, trademark, manufacturer, or otherwise, does not necessarily constitute or imply its endorsement, recommendation, or favoring by the United States Government or any agency thereof. The views and opinions of authors expressed herein do not necessarily state or reflect those of the United States Government or any agency thereof. 


\title{
Deep Residential Retrofits in East Tennessee
}

\author{
Philip Boudreaux \\ Timothy Hendrick \\ Jeff Christian \\ Roderick Jackson
}

Date Published: April 2012

Prepared by

OAK RIDGE NATIONAL LABORATORY

Oak Ridge, Tennessee 37831-6283

managed by

UT-BATTELLE, LLC

for the

U.S. DEPARTMENT OF ENERGY

under contract DE-AC05-00OR22725 


\section{Contents}

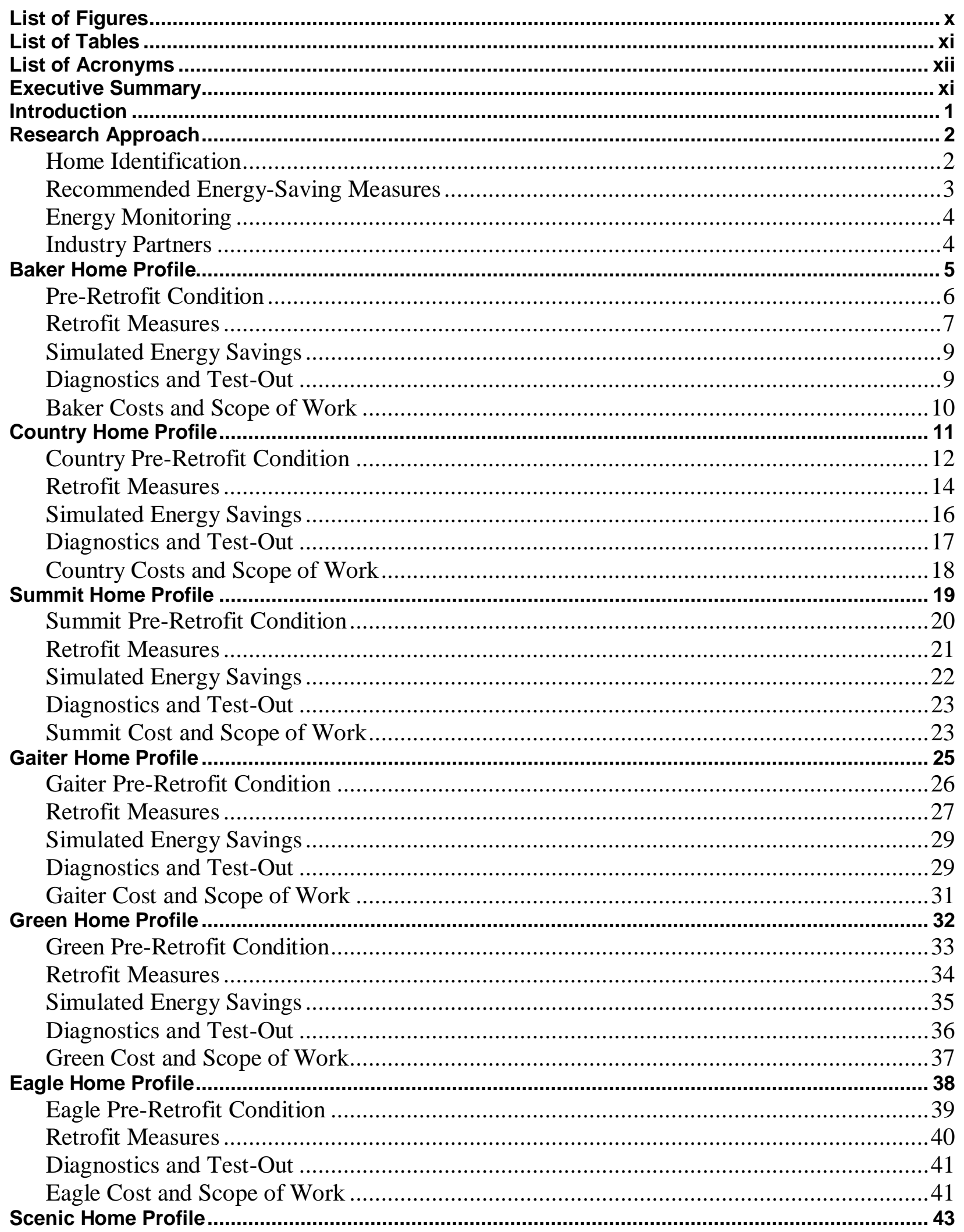




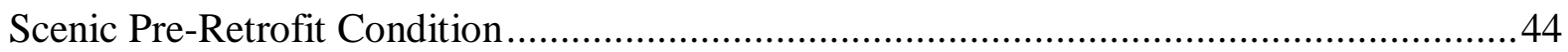

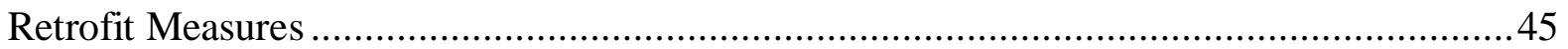

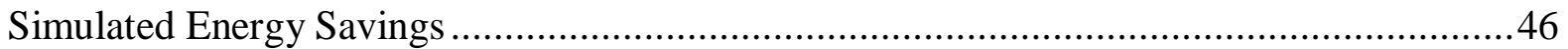

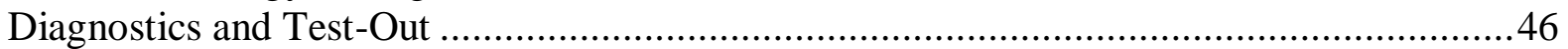

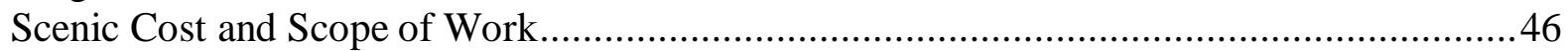

Old Tavern Home Profile ................................................................................................. 48

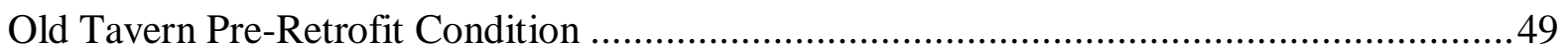

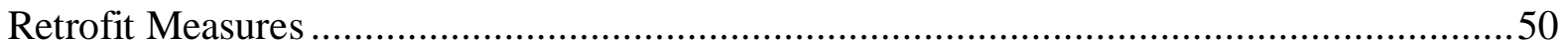

Simulated Energy Savings ..................................................................................... 51

Diagnostics and Test-Out ......................................................................................... 51

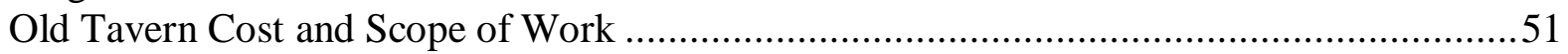

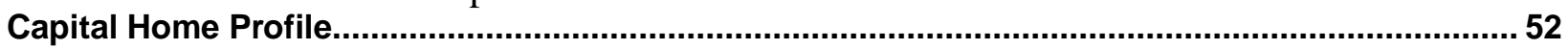

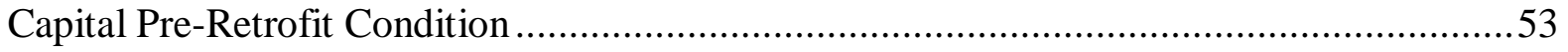

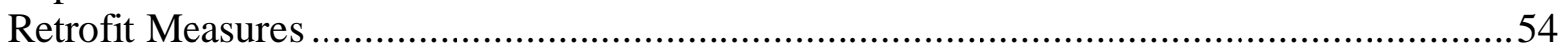

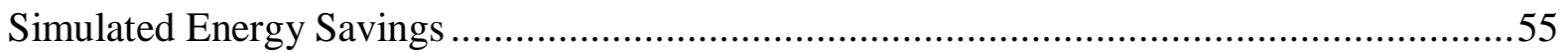

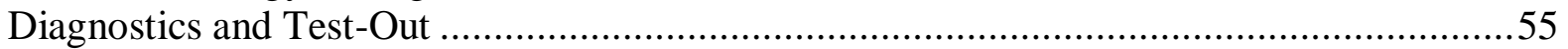

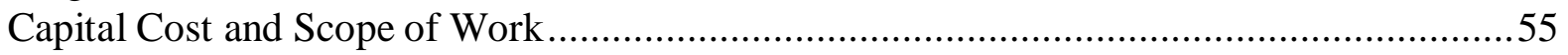

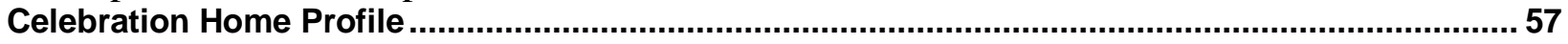

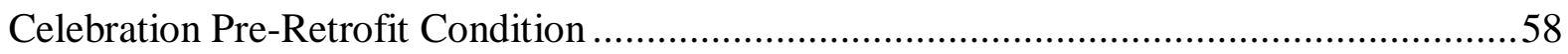

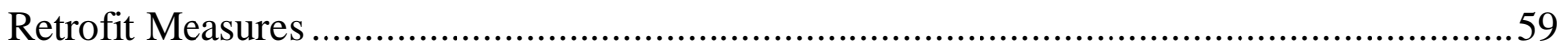

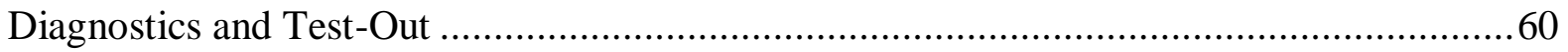

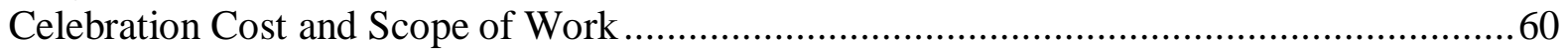

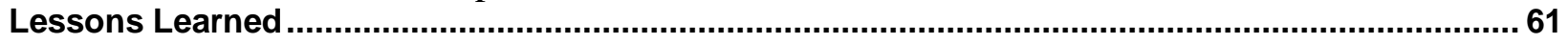

Variability in homeowners' willingness to invest in significant energy retrofits ...................61

Utility bill savings are not the primary driver for energy efficiency retrofits ........................61

Quality of retrofit work is variable among contractors ........................................................66

Estimated Energy Savings of 30\% and greater can be achieved .........................................62

None of the retrofits are estimated to be cost effective .....................................................6. 62

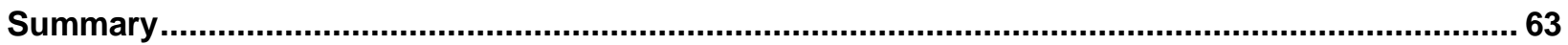

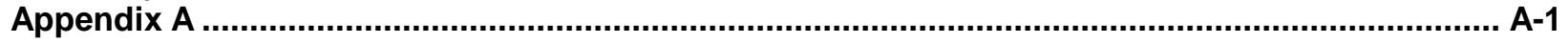

Knoxville News-Sentinel Article (10/29/2009) Larisa Brass ..........................................A-1

Letter and Questionnaire Sent to Interested Homeowners ...............................................A-3

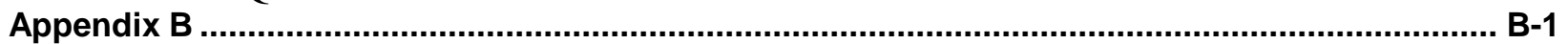

Homeowner Interview Questions ............................................................................. B-1 


\section{List of Figures}

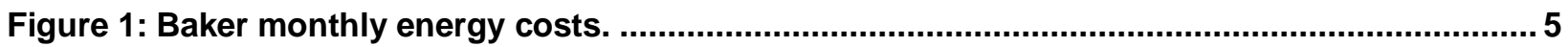

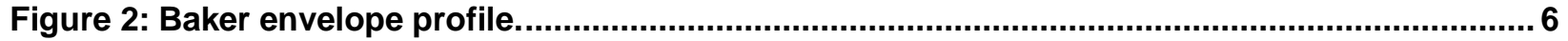

Figure 3: Wall cavities are used as return paths for the Baker HVAC system................................... 7

Figure 4: Sealing conditioned space from flat attic on first floor. Spray foam can be seen on the perimeter between the drop ceiling and the flat attic ceiling rafters. Notice the R-30 batts between the rafters.

Figure 5: Monthly energy costs for the Country home. ............................................................. 11

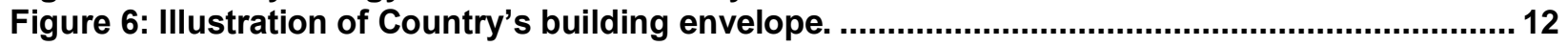

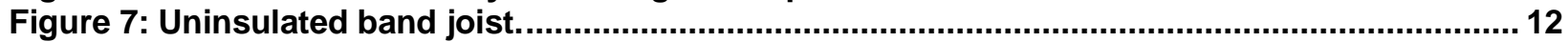

Figure 8: State of insulation in crawl space and attic................................................................ 13

Figure 9: Spray foam insulation on the living room cathedral ceiling and the kitchen walls. ......... 14

Figure 10: Attic knee wall with spray foam.............................................................................. 15

Figure 11: Holes can be seen in the exposed wall were the foam was injected into the wall space.

The existing foam board insulation can also be seen. .............................................................. 15

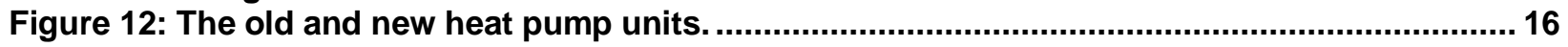

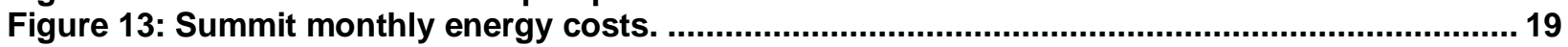

Figure 14: Illustration of Summit's building profile. ..................................................................... 20

Figure 15: Pink latex foam sealing the attic floor.......................................................................... 22

Figure 16: Above-grade basement walls shown during retrofit with foam board and the thin brick

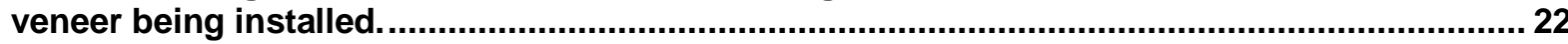

Figure 17: Gaiter initial envelope profile. Dark green indicates a knee wall. The grey walls represent the below-grade walls of the basement. Although this space is not conditioned, it is

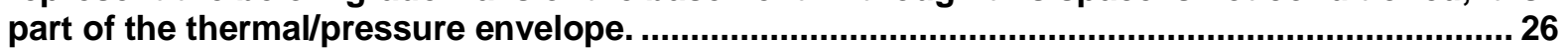

Figure 18: Attic insulation in Gaiter home.............................................................................. 27

Figure 19: Post-retrofit envelope of the Gaiter home. Dark green indicates a knee wall. ................ 28

Figure 20: Pre-retrofit envelope of the Green home. ................................................................ 33

Figure 21: Post-retrofit envelope profile of the Green home......................................................... 34

Figure 22: Sealed attic and the insulated band joist between floors. ............................................. 35

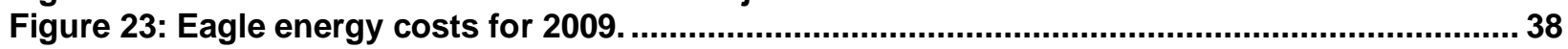

Figure 24: Envelope profile of Eagle. The dark green shade indicates knee walls. ......................... 39

Figure 25: Uninsulated attic knee wall and laundry chute open to attic. ........................................ 40

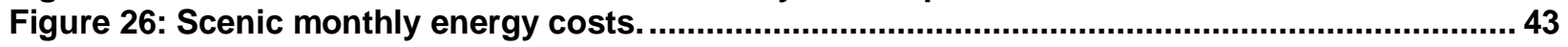

Figure 27: Scenic envelope profile. The dark green represents knee walls. ................................... 44

Figure 28: Insulation in the attic and crawlspace ceiling in the Scenic home is sparse................ 44

Figure 29: Old Tavern monthly energy costs............................................................................... 48

Figure 30: Old Tavern pre-retrofit envelope profile. Dark green represents knee walls. ................ 49

Figure 31: Uninsulated attic knee wall and unsealed attic chase..................................................... 49

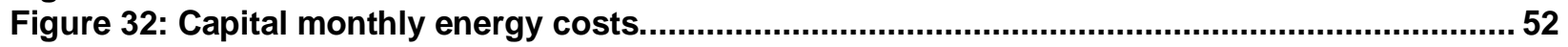

Figure 33: Capital pre-retrofit envelope profile. The dark green represents knee walls. .................53

Figure 34: Moisture issues are apparent in the crawlspace of Capital. ........................................5 53

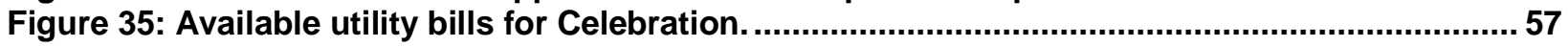

Figure 36: Celebration pre-retrofit envelope profile...................................................................58

Figure 37: Combustion air vent from mechanical closet leading to vented attic. ........................... 58 


\section{List of Tables}

Table 1: Baker retrofit recommendations.

Table 2: EnergyGauge ${ }^{\circledR}$ estimated energy and cost savings for retrofits with neutral cash flow analysis.

Table 3: Pre-retrofit and post-retrofit air infiltration diagnostics .................................................... 9

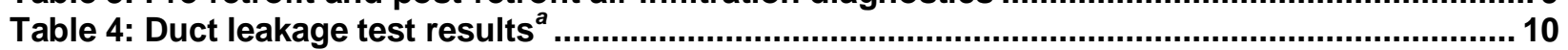

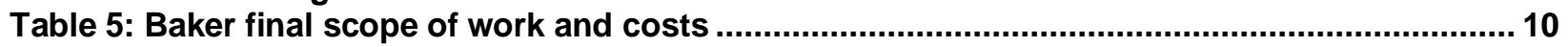

Table 6: Country recommended energy-retrofit list...................................................................... 14

Table 7: EnergyGauge ${ }^{\circledR}$ estimated energy and cost savings for retrofits with neutral cash flow analysis.

Table 8: Air infiltration diagnostics during the retrofit ............................................................... 17

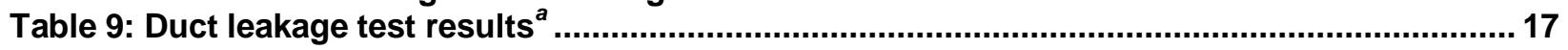

Table 10: Country final scope of work and breakdown of the costs ............................................... 18

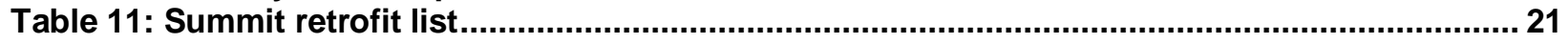

Table 12: EnergyGauge ${ }^{\circledR}$ estimated energy and cost savings for retrofits with neutral cash flow analysis.

Table 13: Pre-retrofit and post-retrofit air infiltration diagnostics ................................................ 23

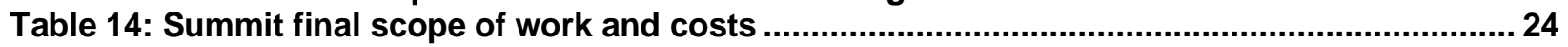

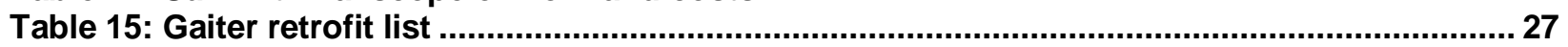

Table 16: EnergyGauge ${ }^{\circledR}$ estimated energy and cost savings for retrofits with neutral cash flow analysis.

Table 17: Pre-retrofit and post-retrofit air infiltration diagnostics ................................................ 30

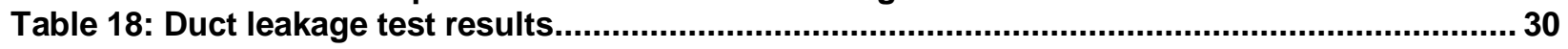

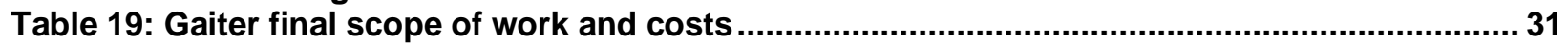

The pre-retrofit lighting, water heater, and appliance specifications are unknown for Green. For modeling purposes, $100 \%$ incandescent bulbs and a 50 -gallon $0.58 \mathrm{EF}$ natural gas water heater were used. For appliances, all the default values in energy gauge were used................ 34

Table 20: Green retrofit list ......................................................................................................... 34

Table 21: EnergyGauge ${ }^{\circledR}$ estimated energy and cost savings for retrofits with neutral cash flow analysis.

Table 22: Pre-retrofit and post-retrofit air infiltration diagnostics ................................................. 36

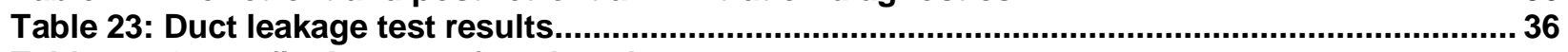

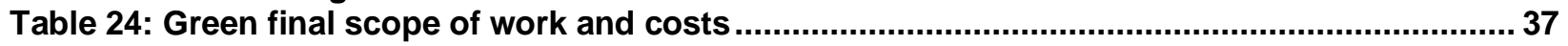

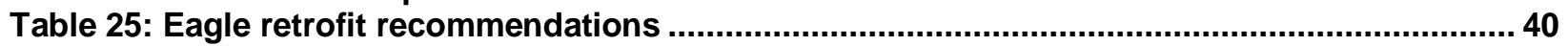

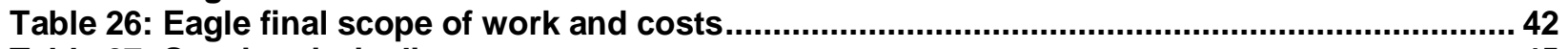

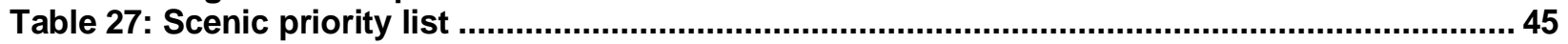

Table 28: EnergyGauge ${ }^{\circledR}$ estimated energy and cost savings for retrofits with neutral cash flow

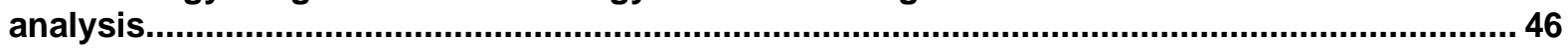

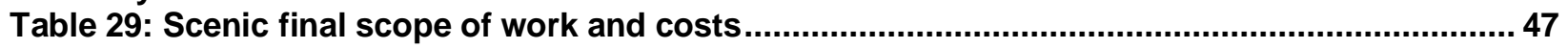

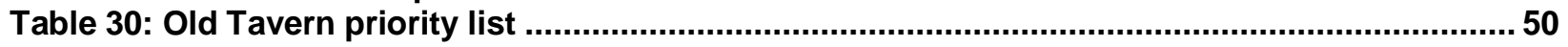

Table 31: EnergyGauge ${ }^{\circledR}$ estimated energy and cost savings for retrofits with neutral cash flow analysis.

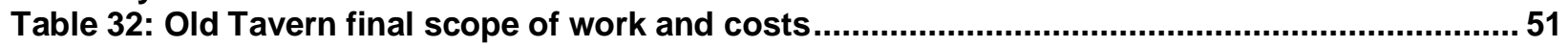

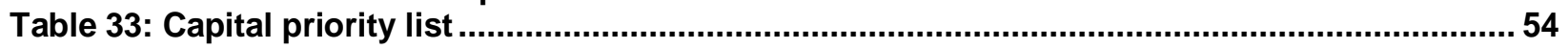

Table 34: EnergyGauge ${ }^{\circledR}$ estimated energy and cost savings for retrofits with neutral cash flow analysis.

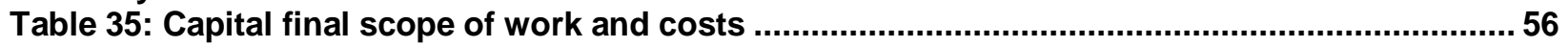

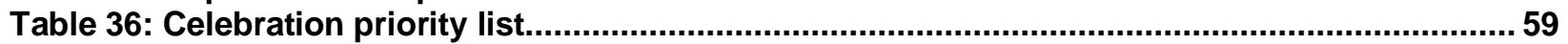

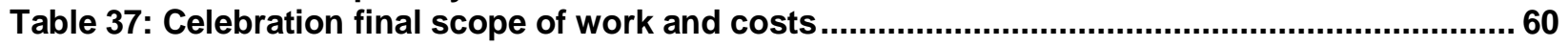

Table 38: Pre- and post-retrofit model information with neutral cost analysis.............................. 64 


\section{List of Acronyms}

$\begin{array}{ll}\mathrm{ACH}_{50} & \text { Air changes per hour at 50 Pascals, infiltration measurement } \\ \mathrm{ACH}_{\text {natural }} & \begin{array}{l}\text { Estimated air changes per hour under natural conditions, infiltration } \\ \text { measurement }\end{array} \\ \text { A/C } & \text { Air-conditioning } \\ \text { AFUE } & \text { Annual fuel utilization efficiency } \\ \text { CFL } & \text { Compact fluorescent lamp } \\ \text { CFM } & \text { Cubic feet per minute, air flow volume measurement } \\ \text { CFM }_{25} & \text { Air flow (CFM) at 25 Pascals, duct leakage measurement } \\ \text { CFM }_{50} & \text { Air flow (CFM) at 50 Pascals, infiltration measurement } \\ \text { DHW } & \text { Domestic hot water } \\ \text { EF } & \text { Efficiency factor } \\ \text { ERV } & \text { Energy recovery ventilator } \\ \text { HERS } & \text { Home energy rating system } \\ \text { HSPF } & \text { Heating season performance factor } \\ \text { LED } & \text { Light Emitting Diode } \\ \text { MEL } & \text { Miscellaneous electric load } \\ \text { NREL } & \text { National Renewable Energy Laboratory } \\ \text { ORNL } & \text { Oak Ridge National Laboratory } \\ \text { PEX } & \text { Cross-linked polyethylene } \\ \text { PV } & \text { Photovoltaic } \\ \text { SEER } & \text { Seasonal energy efficiency ratio } \\ \text { SHGC } & \text { Solar heat gain coefficient } \\ \text { TVA } & \text { Tennessee Valley Authority } \\ \end{array}$




\section{Executive Summary}

Oak Ridge National Laboratory (ORNL) is furthering residential energy retrofit research in the mixed-humid climate of East Tennessee by selecting 10 homes and guiding the homeowners in the energy retrofit process. The homeowners pay for the retrofits, and ORNL advises which retrofits to complete and collects post-retrofit data. This effort is in accordance with the Department of Energy's Building America program research goal of demonstrating market-ready energy retrofit packages that reduce home energy use by 30-50\%. Through this research, ORNL researchers hope to understand why homeowners decide to partake in energy retrofits, how much energy these whole house retrofits actually save, and if the retrofits are cost-effective. Homeowner interviews help the researchers understand the homeowners' experience. Information gathered during the interviews will aid in extending market penetration of home energy retrofits by helping researchers and the retrofit industry understand what drives homeowners in making positive decisions regarding these retrofits.

This interim report summarizes the selection process, the pre-retrofit condition, the recommended retrofits, the actual cost of the retrofits (when available), and an estimated energy savings of the retrofit package using EnergyGauge $\AA$. Of the 10 households selected to participate in the study, only five completed the recommended retrofits, three completed at least one but no more than three of the recommended retrofits, and two households did not complete any of the recommended retrofits. In the case of the two homes that did none of the recommended work, the pre-retrofit condition of the homes and the recommended retrofits are reported.

The five homes that completed the recommended retrofits are monitored for energy consumption of the whole house, appliances, space conditioning equipment, water heater, and most of the other circuits with miscellaneous electric loads (MELs) and lighting. Impact on thermal comfort is also monitored, with temperature and humidity measured in all conditioned zones, attics, crawlspaces, and unconditioned basements. In some homes, heat flux transducers are installed on the basement walls to help determine the insulating qualities of the technologies and practices. EnergyGauge ${ }^{\circledR}$ is used to estimate the pre-retrofit and post-retrofit home energy rating system (HERS) index and reduction in energy consumption and energy bill. A final report will include actual energy savings of the five homes that completed all the retrofits, an analysis of subsystems such as water heating and space conditioning where appropriate and insights gained from the final homeowner interviews. Table ES1 shows the retrofits that were completed at the eight households where some or all of the recommended retrofits were completed. Home aliases are used to keep the homeowners anonymous.

Some key findings of this study thus far are listed below.

- Some homeowners (50\%) are not willing to spend the money to reach 30-50\% energy savings.

- Of the 5 homes that completed the recommended retrofits a total estimated energy savings of $622.8 \mathrm{MMBtu}$ of site energy was saved due to the retrofits. At a total pre- 
retrofit energy consumption of $870.1 \mathrm{MMBtu}$, this amounts to an average of $72 \%$ site energy savings per home. This energy savings includes the subtraction of the site generation of the two installed photovoltaic systems from the post-retrofit energy consumption from the utility. Without considering PV, the total energy savings is 581.3 MMBtu which amounts to an average of $67 \%$ site energy savings per home.

- Of the 5 homes that completed the recommended retrofits, the total cost of these retrofits was $\$ 210,798$, or an average of $\$ 42,200$ per home. Without considering PV, the total cost was $\$ 163,768$, or an average of $\$ 32,800$ per home.

- In none of the five homes is the retrofit considered cost-effective, because a 15 year loan at $7 \%$ interest for the retrofit costs results in yearly energy bill savings that are less than the loan payment.

- Quality of retrofit work is significantly variable among contractors, which impacts the potential energy savings of the retrofit.

- Of the five homes that completed all the recommended retrofits, energy bill savings was not the main driver for energy retrofits. 
Table ES1: Summaries of retrofit measures taken in each home ${ }^{a}$

\begin{tabular}{|c|c|c|c|c|c|c|c|c|c|}
\hline $\begin{array}{c}\text { Home } \\
\text { alias } \\
\text { (square } \\
\text { footage) } \\
\end{array}$ & Exterior walls & $\begin{array}{c}\text { Attic/knee } \\
\text { walls }\end{array}$ & Foundation & Cooling & Heating & DHW & Windows & Misc & $\begin{array}{l}\text { HERS } \\
\text { (pre- } \\
\text { retrofit/ } \\
\text { post- } \\
\text { retrofit) } \\
\end{array}$ \\
\hline $\begin{array}{l}\text { Baker } \\
\left(5210 \mathrm{ft}^{2}\right)\end{array}$ & $\begin{array}{l}1 / 2 \text { to } 1 \text { in. of } \\
\text { closed-cell } \\
\text { spray foam on } \\
\text { perimeter above } \\
\text { drop-ceiling } \\
\text { between first } \\
\text { and second } \\
\text { floor (R-3 to } \\
\text { R-6) } \\
\text { R-9 on band } \\
\text { joist between } \\
\text { first and second } \\
\text { floors (R-3 } \\
1 / 2 \text { in. of foam } \\
\text { board and } 1 \text { in. } \\
\text { of closed-cell } \\
\text { spray foam) }\end{array}$ & $\begin{array}{l}\text { R-38 } \\
\text { fiberglass } \\
\text { batts on attic } \\
\text { floor. } \\
\text { R-19 batts in } \\
\text { attic knee } \\
\text { wall } \\
\text { R-30 batts } \\
\text { against roof } \\
\text { deck in first } \\
\text { floor flat attic }\end{array}$ & $\begin{array}{l}\text { Air sealing of } \\
\text { basement ceiling } \\
\text { with spray foam. } \\
\text { R-22 insulation } \\
\text { on basement } \\
\text { band joist (R-19 } \\
\text { fiberglass batt } \\
\text { and R-3 } 1 / 2 \text { in. of } \\
\text { foam board) }\end{array}$ & $\begin{array}{l}\text { 4-ton, } 16 \\
\text { SEER }\end{array}$ & $\begin{array}{l}\text { HSPF } 9.5 \\
\text { with gas } \\
\text { backup } \\
\text { (90 kBtuh, } \\
\text { 95\% AFUE) }\end{array}$ & $\begin{array}{l}2.4 \mathrm{EF} \\
\text { electric } \\
\text { heat pump } \\
\text { water } \\
\text { heater }\end{array}$ & Air sealed & $\begin{array}{l}\text { Weather } \\
\text { stripped and } \\
\text { sealed doors; } \\
\text { replaced } \\
\text { garage and } \\
\text { basement } \\
\text { doors } \\
\text { Supply ducts } \\
\text { replaced and } \\
\text { other ducts } \\
\text { sealed with } \\
\text { mastic where } \\
\text { accessible } \\
\text { R-6 duct } \\
\text { insulation }\end{array}$ & $\begin{array}{l}(119 / 75) \\
\text { Projected } \\
\text { site energy } \\
\text { savings: } \\
50.6 \\
\text { MMBtu }\end{array}$ \\
\hline
\end{tabular}




\begin{tabular}{|c|c|c|c|c|c|c|c|c|c|}
\hline $\begin{array}{c}\text { Home } \\
\text { alias } \\
\text { (square } \\
\text { footage) }\end{array}$ & Exterior walls & $\begin{array}{l}\text { Attic/knee } \\
\text { walls }\end{array}$ & Foundation & Cooling & Heating & DHW & Windows & Misc & \begin{tabular}{|l|} 
HERS \\
(pre- \\
retrofit/ \\
post- \\
retrofit)
\end{tabular} \\
\hline $\begin{array}{l}\text { Country } \\
\left(2448 \mathrm{ft}^{2}\right)\end{array}$ & $\begin{array}{l}\text { Spray foam } \\
\text { insulation } \\
\text { (hybrid } \\
\text { closed/open cell } \\
\text { formula) used in } \\
\text { exterior walls } \\
\text { (R-14); kitchen } \\
\text { wall insulation } \\
\text { increased to } \\
\text { R-24 with flash } \\
\text { and batt method } \\
\\
\text { Siding replaced } \\
\text { with new R-5.3 } \\
\text { backed siding }\end{array}$ & $\begin{array}{l}\text { Sealed attic } \\
\text { floor, R-50 } \\
\text { blown } \\
\text { fiberglass on } \\
\text { attic floor } \\
\\
\text { Knee wall: } \\
\text { R-19 batts, } \\
2 \text { in. of foam } \\
\text { board on } \\
\text { outside of } \\
\text { studs (R-10), } \\
1 / 2 \text { in. of spray } \\
\text { foam over } \\
\text { foam board } \\
\text { (R-3) }\end{array}$ & $\begin{array}{l}\text { Band joist in } \\
\text { basement: } 2 \text { in. } \\
\text { of foam board } \\
\text { with } 1 \text { in. of } \\
\text { closed-cell spray } \\
\text { foam (R-16) } \\
\text { Band joist in } \\
\text { crawlspace: } 2 \text { in. } \\
\text { of foam board } \\
\text { with } 2 \text { in. of } \\
\text { spray foam } \\
\text { (R-22) } \\
\text { Cathedral ceiling } \\
\text { was insulated to } \\
\text { R-24 }\end{array}$ & $\begin{array}{l}3 \text { ton, } \\
19 \text { SEER }\end{array}$ & HSPF 9 & $\begin{array}{l}2.4 \mathrm{EF} \\
\text { electric } \\
\text { heat pump } \\
\text { water } \\
\text { heater }\end{array}$ & $\begin{array}{l}\text { U-Factor } 0.3 \\
\text { SHGC } 0.2\end{array}$ & $\begin{array}{l}96 \% \mathrm{CFL} \\
\\
\text { ENERGY } \\
\text { STAR® } \\
\text { refrigerator } \\
\text { Duct sealing }\end{array}$ & $\begin{array}{l}(100 / 66) \\
\text { Projected } \\
\text { site } \\
\text { energy } \\
\text { savings: } \\
33.5 \\
\text { MMBtu }\end{array}$ \\
\hline
\end{tabular}




\begin{tabular}{|c|c|c|c|c|c|c|c|c|c|}
\hline $\begin{array}{c}\text { Home } \\
\text { alias } \\
\text { (square } \\
\text { footage) }\end{array}$ & Exterior walls & $\begin{array}{c}\text { Attic/knee } \\
\text { walls }\end{array}$ & Foundation & Cooling & Heating & DHW & Windows & Misc & \begin{tabular}{|l|} 
HERS \\
(pre- \\
retrofit/ \\
post- \\
retrofit)
\end{tabular} \\
\hline $\begin{array}{l}\text { Summit } \\
\left(3110 \mathrm{ft}^{2}\right)\end{array}$ & $\begin{array}{l}\text { Walls between } \\
\text { first floor and } \\
\text { garage were } \\
\text { sealed and } \\
\text { insulated with } \\
\text { batts (R-19) and } \\
\text { then covered } \\
\text { with 2 in. of } \\
\text { foam panels } \\
\text { (R-10) } \\
\text { 1/2 in. thick } \\
\text { Structural } \\
\text { insulated } \\
\text { sheathing } \\
\text { (R-2.74) was } \\
\text { used before } \\
\text { siding was } \\
\text { added }\end{array}$ & \begin{tabular}{|l|} 
Sealed attic \\
floor, R-60 \\
blown \\
fiberglass on \\
attic floor \\
\\
Knee wall: \\
2 in. of foam \\
panels \\
(R-10), sealed \\
and with air \\
barrier wrap \\
\end{tabular} & $\begin{array}{l}2 \text { in. of spray } \\
\text { foam was added } \\
\text { to band joist } \\
\text { cavities (R-10) } \\
\text { Crawlspace } \\
\text { walls were } \\
\text { insulated with } \\
\text { foam panels or } \\
\text { batts (R-10) } \\
\text { The above-grade } \\
\text { portion of three } \\
\text { basement walls } \\
\text { were insulated } \\
\text { on the outside } \\
\text { with } 2 \text { in. of } \\
\text { foam panels (R- } \\
10) \text { and covered } \\
\text { in 1/2-in. thin- } \\
\text { brick veneer } \\
\\
\text { Sealed fourth } \\
\text { framed basement } \\
\text { wall with latex } \\
\text { foam then } \\
\text { insulated with } \\
\text { fiberglass batts } \\
\text { (R-19) }\end{array}$ & $\begin{array}{l}2 \text { variable- } \\
\text { speed multi- } \\
\text { split heat } \\
\text { pumps @ } \\
4 \text { ton, } \\
15 \text { SEER }\end{array}$ & $\begin{array}{l}\text { HSPF } 8.7 \\
\end{array}$ & & $\begin{array}{l}\text { U-factor } 0.2 \\
\text { (0.1 for quad } \\
\text { pane } \\
\text { windows), } \\
\text { SHGC } 0.35\end{array}$ & $\begin{array}{l}8.5-\mathrm{kW}_{\text {peak }} \\
\mathrm{PV}\left(10^{\circ}\right. \\
\text { azimuth, } 30^{\circ} \\
\text { tilt }) \\
100 \% \mathrm{CFL}\end{array}$ & $\begin{array}{l}(119 / 23) \\
\text { Projected } \\
\text { site energy } \\
\text { savings: } \\
135 \\
\text { MMBtu }\end{array}$ \\
\hline
\end{tabular}




\begin{tabular}{|c|c|c|c|c|c|c|c|c|c|}
\hline $\begin{array}{c}\begin{array}{c}\text { Home } \\
\text { alias } \\
\text { (square } \\
\text { footage) }\end{array} \\
\end{array}$ & Exterior walls & $\begin{array}{c}\text { Attic/knee } \\
\text { walls }\end{array}$ & Foundation & Cooling & Heating & DHW & Windows & Misc & $\begin{array}{l}\text { HERS } \\
\text { (pre- } \\
\text { retrofit/ } \\
\text { post- } \\
\text { retrofit) }\end{array}$ \\
\hline $\begin{array}{l}\text { Green } \\
\left(2295 \mathrm{ft}^{2}\right)\end{array}$ & $\begin{array}{l}\text { Weather wrap } \\
\text { fabric on walls; } \\
\text { walls insulated } \\
\text { to R-16 }\end{array}$ & $\begin{array}{l}\text { R-38 closed- } \\
\text { cell foam on } \\
\text { underside of } \\
\text { roof deck } \\
\text { Weather wrap } \\
\text { from the } \\
\text { walls } \\
\text { extended into } \\
\text { the closed } \\
\text { soffits and } \\
\text { rakes; then } \\
\text { open-cell } \\
\text { foam was } \\
\text { blown into } \\
\text { the soffits and } \\
\text { rakes }\end{array}$ & $\begin{array}{l}\text { Foam panels } \\
\text { were applied on } \\
\text { interior basement } \\
\text { walls to R-10 } \\
\\
\text { A vapor barrier } \\
\text { was applied on } \\
\text { dirt floor and up } \\
\text { the walls of the } \\
\text { basement on top } \\
\text { of the foam } \\
\text { panels }\end{array}$ & $\begin{array}{l}\text { 3-ton } \\
\text { 20.5 SEER } \\
\text { (variable } \\
\text { capacity } \\
\text { ducted) }\end{array}$ & HSPF 13 & $\begin{array}{l}\text { Active } \\
\text { indirect } \\
\text { solar } \\
\text { DHW }\end{array}$ & $\begin{array}{l}\text { U-factor } 0.3 \text {, } \\
\text { SHGC } 0.2\end{array}$ & $\begin{array}{l}1.428-\mathrm{kW}_{\text {peak }} \\
\text { laminate PV } \\
78 \% \mathrm{CFL}\end{array}$ & $\begin{array}{l}(186 / 61) \\
\text { Projected } \\
\underline{\text { site }} \\
\text { energy } \\
\frac{\text { savings: }}{171.5} \\
\text { MMBtu }\end{array}$ \\
\hline
\end{tabular}




\begin{tabular}{|c|c|c|c|c|c|c|c|c|c|}
\hline $\begin{array}{c}\text { Home } \\
\text { alias } \\
\text { (square } \\
\text { footage) }\end{array}$ & Exterior walls & $\begin{array}{c}\text { Attic/knee } \\
\text { walls }\end{array}$ & Foundation & Cooling & Heating & DHW & Windows & Misc & $\begin{array}{l}\text { HERS } \\
\text { (pre- } \\
\text { retrofit/ } \\
\text { post- } \\
\text { retrofit) }\end{array}$ \\
\hline $\begin{array}{l}\text { Gaiter } \\
\left(1769 \mathrm{ft}^{2}\right)\end{array}$ & $\begin{array}{l}1 \text { in. of closed- } \\
\text { cell foam and } \\
\text { R-13 fiberglass } \\
\text { batts in above- } \\
\text { grade walls } \\
\text { (total R-16) }\end{array}$ & \begin{tabular}{|l|}
1 in. of \\
closed-cell \\
spray foam \\
was applied \\
to underside \\
of roof deck, \\
then topped \\
with 8 in. of \\
open-cell \\
foam (total \\
R-34) \\
\\
Ridge and \\
soffit vents \\
were stuffed \\
with \\
fiberglass \\
batts and then \\
foamed over \\
with closed \\
cell foam \\
Sunroom roof \\
deck with \\
cathedral \\
ceiling was \\
sprayed with \\
4 in. of \\
closed-cell \\
foam (R-24)
\end{tabular} & $\begin{array}{l}\text { Band joist in } \\
\text { basement sealed } \\
\text { with } 1 \text { in. of } \\
\text { closed cell foam } \\
\text { (R-6) } \\
\text { Framed above- } \\
\text { grade south } \\
\text { basement wall } \\
\text { was sealed with } \\
1 / 2 \text { in. of closed- } \\
\text { cell spray foam } \\
\text { and insulated } \\
\text { with R-13 } \\
\text { fiberglass batts }\end{array}$ & $\begin{array}{l}\text { 3-ton } \\
18 \text { SEER heat } \\
\text { pump }\end{array}$ & HSPF 9.5 & $\begin{array}{l}2.4 \mathrm{EF} \\
\text { electric } \\
\text { heat pump } \\
\text { water } \\
\text { heater }\end{array}$ & $\begin{array}{l}\text { U-factor } 0.2 \text {, } \\
\text { SHGC } 0.35\end{array}$ & \begin{tabular}{|l} 
ENERGY \\
STAR® \\
refrigerator \\
$90 \% \mathrm{CFL}$
\end{tabular} & $\begin{array}{l}(259 / 75) \\
\text { Projected } \\
\text { site energy } \\
\frac{\text { savings: }}{232} \\
\text { MMBtu }\end{array}$ \\
\hline
\end{tabular}




\begin{tabular}{|c|c|c|c|c|c|c|c|c|c|}
\hline $\begin{array}{c}\text { Home } \\
\text { alias } \\
\text { (square } \\
\text { footage) }\end{array}$ & Exterior walls & $\begin{array}{c}\text { Attic/knee } \\
\text { walls }\end{array}$ & Foundation & Cooling & Heating & DHW & Windows & Misc & $\begin{array}{l}\text { HERS } \\
\text { (pre- } \\
\text { retrofit/ } \\
\text { post- } \\
\text { retrofit) }\end{array}$ \\
\hline $\begin{array}{l}\text { Scenic } \\
\left(4328 \mathrm{ft}^{2}\right)\end{array}$ & & $\begin{array}{l}\text { R-38 blown } \\
\text { fiberglass on } \\
\text { attic floor }\end{array}$ & & $\begin{array}{l}3 \text { ton, } \\
16 \text { SEER }\end{array}$ & HSPF 9 & & & $100 \%$ CFL & $\begin{array}{l}(135 / 119) \\
\text { Projected } \\
\text { site energy } \\
\text { savings: } \\
\text { 46 MMBtu }\end{array}$ \\
\hline $\begin{array}{l}\text { Old } \\
\text { Tavern } \\
\left(3766 \mathrm{ft}^{2}\right)\end{array}$ & & & $\begin{array}{l}\text { Sealed } \\
\text { crawlspace }\end{array}$ & & & & & & $\begin{array}{l}(133 / 130) \\
\text { Projected } \\
\text { site energy } \\
\frac{\text { savings: }}{7.6} \\
\text { MMBtu } \\
\end{array}$ \\
\hline $\begin{array}{l}\text { Capital } \\
\left(2438 \mathrm{ft}^{2}\right)\end{array}$ & & & $\begin{array}{l}\text { Sealed } \\
\text { crawlspace/ } \\
\text { insulated } \\
\text { crawlspace walls } \\
\text { to R-10 }\end{array}$ & & & $\begin{array}{l}\text { Tankless } \\
\text { water } \\
\text { heater }\end{array}$ & & $100 \%$ CFL & $\begin{array}{l}(115 / 97) \\
\text { Projected } \\
\text { site energy } \\
\frac{\text { savings: }}{15 \text { MMBtu }}\end{array}$ \\
\hline
\end{tabular}

${ }^{a} \mathrm{DHW}=$ domestic hot water; CFL = compact fluorescent lamp; EF = efficiency factor; SHGC = solar heat gain coefficient; SEER = seasonal energy efficiency ratio; $\mathrm{HSPF}=$ heating season performance factor, $\mathrm{AFUE}=$ annual fuel utilization efficiency, $\mathrm{PV}=$ photovoltaic, $\mathrm{HERS}=$ home energy rating system. 


\section{Introduction}

The residential building sector used 22 percent of the nation's energy in $2010{ }^{*}$ The DOE Building Technologies Program is focused on increasing the energy efficiency of new and existing homes to benefit the nation's energy outlook. The Department of Energy's Building America program has a research goal of demonstrating market-ready energy retrofit packages that reduce home energy use by $30-50 \%$. Oak Ridge National Laboratory (ORNL) is furthering deep residential energy retrofit research in the mixed-humid climate of East Tennessee by selecting 10 homes and guiding the homeowners in the energy retrofit process. The homeowners pay for the retrofits, and ORNL advises which retrofits to complete and collects post-retrofit data. Through this research, ORNL researchers hope to understand why homeowners decide to partake in energy retrofits, how much energy these whole house retrofits actually save, and if the retrofits are cost-effective. Homeowner interviews help the researchers understand the homeowners' experience. Information gathered during the interviews will aid in extending market penetration of home energy retrofits by helping researchers and the retrofit industry understand what drives homeowners in making positive decisions regarding these retrofits.

This report will summarize the selection process, the pre-retrofit condition, the recommended retrofits, the actual cost of the retrofits, and the estimated energy savings of the retrofit package using EnergyGauge ${ }^{\circledR}$. Unfortunately the homeowners of two homes chose to do none of the recommended energy retrofits, and the homeowners of three homes chose to do only some of the recommended work. In the case of the other five homes which completed all of the recommended retrofits, all are monitored for post-retrofit energy use of the whole house and individual end uses, thermal comfort, and heat flux of the foundation walls.

EnergyGauge ${ }^{\circledR}$ models of the homes' pre- and post-retrofit conditions are used to estimate energy and utility bill savings and pre- and post-retrofit HERS indices and are presented in the text. A final report will include actual energy savings of the five homes that completed all the retrofits, an analysis of sub-systems such as water heating and space conditioning where appropriate and insights gained from the final homeowner interviews.

The most interesting findings of this study are that only $50 \%$ of the selected homeowners completed the recommended retrofits. The two main reasons that the homeowners gave for not yet completing the retrofits were that the cost of the work was too high and that they wanted to better understand the technologies and practices of energy retrofits before starting to do work. Of the five homes that completed the retrofits an average of $72 \%$ site energy is estimated to be saved, at the average retrofit cost of $\$ 42,200$ per home. These retrofits were not cost effective as the yearly energy bill savings were less than the yearly loan payment. It can be noted that $72 \%$ savings is higher than the target $30-50 \%$ energy savings, so maybe we should not expect them to be cost effective. However, the two homes with energy savings within this range are still not estimated to be cost effective.

\footnotetext{
* Buildings Energy Data Book. U.S. DOE, Energy Efficiency and Renewable Energy. 2011. E-book: http://buildingsdatabook.eren.doe.gov
} 


\section{Research Approach}

\section{Home Identification}

To identify homes that could participate in this study, several presentations were given in East Tennessee on home energy retrofits, including one at ORNL and one in the Farragut Town Hall. An article describing the study was also published in a local newspaper, the Knoxville NewsSentinel. In the presentations, this study was explained and contact information was provided so that anyone interested could volunteer for participation in the study. A questionnaire was given to those who expressed interest. (The newspaper article and the questionnaire are provided in Appendix A.)

Initial criteria were developed for potential homes and as follows.

- No less than 15 years old and ideally at a stage of life where major renovations are needed

- Occupied year-round (not seasonally)

- Windows not frequently open when heating or cooling system is on

- Has central heating and cooling system

- Does not have energy-intensive home-based businesses or hobbies

- Does not have a whole-house fan, or if it does, the fan is not operated

- Homeowner agrees to cover costs of all retrofits

Once the owners of potential homes were identified, and they agreed to participate in the study, an independent home energy rating system (HERS) rater conducted a physical test-in* of each home, and ORNL behavioral scientists conducted homeowner interviews. The test-in included the following.

- homeowner interview

- building characterization

- blower door depressurization test

- duct leakage test

The homeowner interview questions are provided in Appendix B. The intent of the initial interview was to gain an understanding as to why the homeowners decided to perform energy retrofits, what influenced their decision, and to help the researchers understand the homeowners' living habits. Subsequent interviews, one during the retrofit work and one ideally 1 year after the work is complete, have or will be done. The interview during the retrofit work was used to determine how the retrofit work influenced the homeowner. The interview one year after the

\footnotetext{
*"Test-in" is used to describe the pre-retrofit energy audit.
} 
retrofit work is complete will help the researchers understand how the homeowner feels regarding the outcome of the retrofit.

In two of the homes included in this study (Gaiter and Green), no mechanical equipment was installed in the home when the retrofit began which made building characterization more challenging. Since comparing the post-retrofit energy consumption to the pre-retrofit home is instrumental in determining energy savings it is important to calculate a baseline energy consumption of the home for comparison. Furthermore, since these mechanical systems must be estimated it is important that they are carefully chosen so that they reflect reality as closely as possible. In these cases it was assumed that mechanical equipment was 15 years old. To estimate the capacities of the cooling and heating systems, rules of thumb were used just as they were likely used when this proposed equipment would have been installed. The cooling system capacity is estimated to be 1 ton for every $600 \mathrm{ft}^{2}$ of conditioned floor area. The heating system output capacity is estimated to be 40 Btuh per square foot of conditioned floor area. The efficiencies of the system are estimated using the Building America House Simulation Protocols." For the duct leakage, it was assumed that the normalized duct leakage to the outside was $35 \%$ of the conditioned floor area, since the default leakage in EnergyGauge ${ }^{\circ}$ was too conservative.

The houses were given the following aliases to keep the anonymity of the homeowners: Baker, Country, Summit, Green, Gaiter, Eagle, Scenic, Old Tavern, Capital, and Celebration.

The floor area of each home is defined as being any floor area that is intentionally conditioned. This would include an unfinished basement that is conditioned but not a sealed attic, unconditioned basement, or unconditioned sealed crawlspace. In most cases, the house volume is defined as the floor area defined above multiplied by the appropriate ceiling heights. In the case of the Gaiter home, the unfinished unconditioned basement is included in the house volume because it is more connected with the house than the outside as there is no thermal or pressure boundary between them. The building profile image for each home illustrates the envelope of the home - the pressure and thermal boundary. Sometimes this will be the same as the house volume used for calculating air changes per hour $(\mathrm{ACH})$. For example, a home that has an attic with the roof deck sealed and insulated would have the roof deck considered as the pressure/thermal boundary, but this volume of the attic would not be added to the whole house volume for air infiltration calculations. This is, in part, to stay consistent in the comparison between pre- and post-retrofit conditions of the home.

In some cases, the duct leakage to the outside was too great to measure. Unfortunately, in these cases no information was recorded. When this was the case, the researchers assumed the duct leakage to the outside was $35 \%$ of the conditioned floor area. In the case of Baker, since the unit is undersized for the floor area, this estimation yielded a duct leakage greater than $100 \%$ of the estimated fan flow. In this case, the leakage was estimated to be $35 \%$ of the estimated fan flow (360 cfm/ton).

\section{Recommended Energy-Saving Measures}

\footnotetext{
" Hendron and Engebrecht, NREL, Building America House Simulation Protocols, Revised October 2010. http://www.nrel.gov/docs/fy11 osti/49246.pdf
} 
All ten ORNL selected homes received a TVA Energy Right ${ }^{\circledR}$ audit. During this audit a TVAcertified auditor surveys the home and makes suggestions for increasing the home's energy efficiency. The cost of the audit was $\$ 150$ and has now been reduced to $\$ 50$, but this cost is reimbursed with the addition of up to $\$ 500$ in rebates if the recommended work is completed by the homeowner. ORNL, taking into account the TVA Energy Right ${ }^{\circledR}$ audit recommendations, and the HERS rater "test-in" findings, made recommendations to the homeowner concerning energy retrofits. ORNL used the whole-house approach, tackling first the envelope, specifically the air infiltration. Either concurrently or subsequently the envelope's insulation was increased. After the work concerning the envelope was done, the HVAC system could be properly sized and installed. Then water heating, appliances, and lighting were retrofitted. Since each house was different, not all of these steps will be recommended. As the researchers discovered, sometimes the homeowners have specific reasons not to undergo certain retrofit recommendations, and do not follow the progression described above. These will be discussed on a house-by-house basis.

Energy savings were estimated using the EnergyGauge ${ }^{\circledR}$ energy simulation tool. The five homes that completed the recommended retrofits underwent a "test-out" procedure which included a blower door test, and a duct leakage to the outside test (if the ductwork was sealed or replaced), and a post-retrofit building characterization.

\section{Energy Monitoring}

Campbell Scientific data loggers were installed in the five houses that completed all the recommended retrofits. The data loggers record energy, temperature, humidity, gas flow, water flow, and heat flux. The data loggers sample data every 30 seconds and save an average or total to memory every 15 minutes. Since the data loggers were installed during the retrofit, no preretrofit data from the data loggers are available. Only the total energy use of the home, from monthly energy bills, can be compared pre- and post-retrofit. Monthly energy bills were obtained for eight out of the ten homes. Two of the homes were unoccupied for at least 3 years prior to the retrofit.

\section{Industry Partners}

Research partners and their roles are as follows.

- TVA provides some funding for this project and completes the Energy Right ${ }^{\circledR}$ energy audits.

- Owens Corning provides use of an internally created home energy auditing tool.

- Bruce Granville is an independent HERS rater who conducted the "test-in" of all the homes.

- Carrier donated a variable-capacity ducted HVAC unit for one home. 


\section{Baker Home Profile}

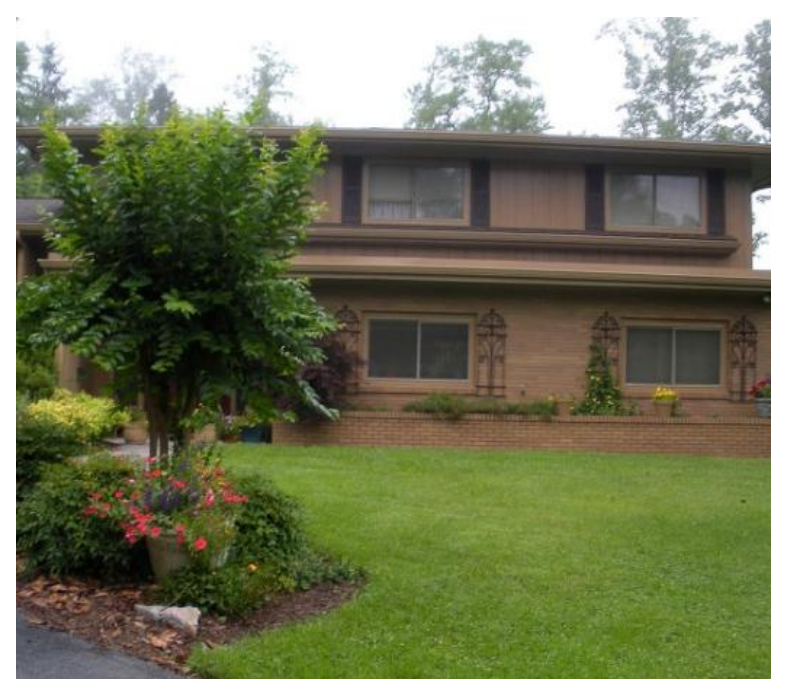

Originally built in 1966, Baker is a two-story, single-family detached home with $5,210 \mathrm{ft}^{2}$ of living area. The first living level has a floor area of $1,537 \mathrm{ft}^{2}$, the second living level is $1,209 \mathrm{ft}^{2}$, and the third bedroom level is $1,374 \mathrm{ft}^{2}$. The basement makes up the rest of the conditioned floor area with 1,090 $\mathrm{ft}^{2}$. Baker is home to a family of one adult and two children. The home has six bedrooms, three full bathrooms and two half bathrooms. Baker has a vented attic, an unfinished conditioned basement, and a slab. Baker also has an unconditioned attached garage on the west side of the home.

Energy bills from January 2008-December 2008 are shown in Figure 1. With an annual cost of $\$ 2,535$ and site energy use of $128 \mathrm{MMBtu}(13,720 \mathrm{kWh}$ and 816 therms), energy consumption of this home is about half that of an average home of similar size in the Southeast. ${ }^{*}$ This is due in large part to the size of the home with respect to number of occupants and is not necessarily an indicator of the home's energy efficiency.

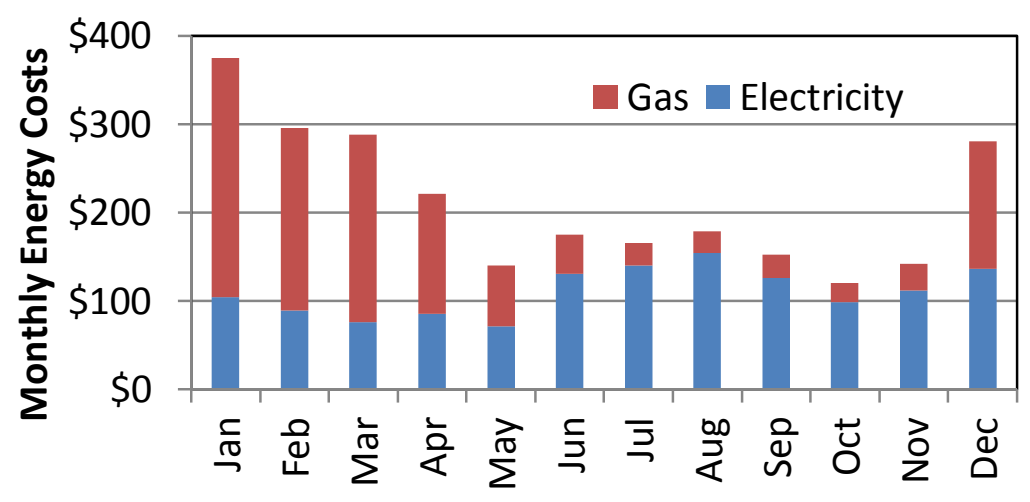

Figure 1: Baker monthly energy costs.

\footnotetext{
*Per the 2010 Buildings Energy Data Book, energy consumption for the South Atlantic region is 47.4 kBtu per square foot. A similar home of this size would have an average annual energy consumption of $247 \mathrm{MMBtu}$.
} 
BAKER PRE-RETROFIT

\section{CHARACTERISTICS}

TYPE: Two-story, single-family

home

SIZE: $5,210 \mathrm{ft}^{2}$

Occupancy: One adult and two children

\section{INITIAL ENVELOPE}

\section{PROFILE}

BASEMENT CEILING INSULATION:

NONE

BASEMENT WALL INSULATION:

None

WALL INSULATION: R-11 AND

R-4.5

ATTIC FLOOR INSULATION: R-30

CATHEDRAL ATTIC INSULATION:

R-19

KNEE WALL INSULATION: R-9

\section{INITIAL MECHANICAL}

\section{ProfiLe}

\section{HVAC:}

Location: Conditioned Basement

Cooling: 4 ton, 10 SEER HP

Heating: 7.7 HSPF (with

hydronic backup)

WATER HEATER: $0.51 \mathrm{EF}$ (natural gas) 80 gallons

\section{INITIAL DIAGNOSTIC}

\section{RESULTS}

HERS: 119

AIR INFILTRATION:

$7,842 \operatorname{cfm}_{50}\left(10.3 \mathrm{ACH}_{50}\right)$

DUCT LEAKAGE TO OUTSIDE:

$504 \mathrm{cfm}_{25}$ (estimated)

DUCT INSULATION: R-4

\section{Pre-Retrofit Condition}

\section{Envelope Profile}

An illustration of the building envelope is shown in Figure 2. The basement has a concrete floor and uninsulated concrete block walls. The band joist is uninsulated. The walls of levels 2 and 3 are wood framed with R-11 cavity insulation. Level 1 has concrete block walls furred with $2 \times 4$ studs laid on the wide end against the block with $1.5 \mathrm{in}$. batt insulation and drywall over the furring strips. There is an architectural feature on the front of level 1 (see Figure 2) with a flat cathedral attic and soffit vents that have a direct path into the space between level 1 and level 3. The attic above level 3 has R-30 insulation on the attic floor. Level 2 has a cathedral ceiling with R-19 insulation. Level 2 has a knee wall, shown in dark green, which faces the attic above the garage. The knee wall has R-9 fiberglass batt cavity insulation.

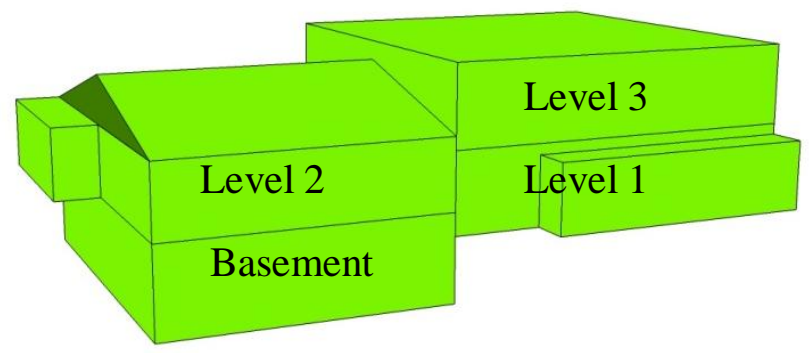

Figure 2: Baker envelope profile.

The attic access in the home has no insulation or weather-stripping. Utility penetrations in the attic floor and basement ceiling need to be sealed, and the windows are in need of caulking. The windows in the home are clear double pane with metal frames (U value: 0.57 and SHGC: 0.56). The exterior cladding on the building is brick and board siding. There is a half bath/washroom coming off level 2 into the garage. This room is conditioned, but the pocket door that connects it to the garage does not seal. During the initial home audit, a blower door test was conducted to evaluate the air infiltration. The total air leakage rate was $7,842 \mathrm{cfm}_{50}$ (cubic feet per minute at 50 Pascals). With a conditioned volume of $45,773 \mathrm{ft}^{3}$, the air infiltration for Baker was approximately $10.3 \mathrm{ACH}_{50}$ (air changes per hour at 50 Pascals). 


\section{HVAC}

Conditioned air is provided by a 4-ton capacity heat pump with an efficiency of 10 seasonal energy efficiency ratio (SEER) and 7.7 heating season performance factor (HSPF). The unit is equipped with a hydronic gas backup system. The mechanical equipment is located in the conditioned basement. The ductwork is in the basement, walls, and above the tile drop ceiling in level 1, with visible ductwork having R-4 insulation. Wall cavities are used as return ducts in much of the home (see Figure 3). Duct leakage to the outside was not able to be measured because the duct system was too leaky. For modeling purposes, the duct leakage is estimated to be $35 \%$ of the HVAC fan flow ( $360 \mathrm{cfm} / \mathrm{ton}$ ). In the case of Baker, this is $504 \mathrm{cfm}_{25}$.
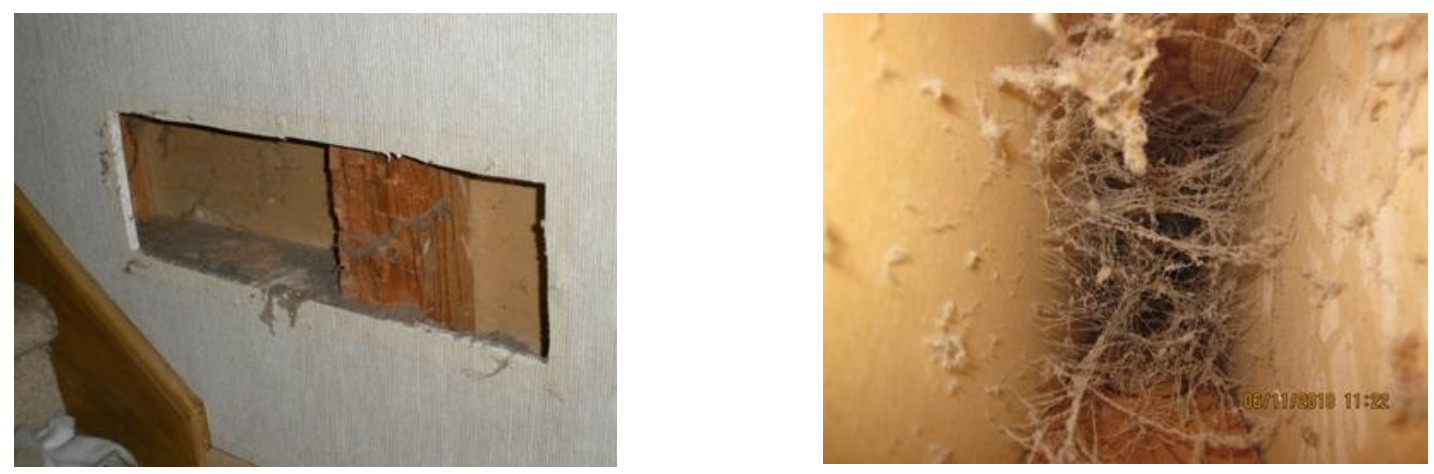

Figure 3: Wall cavities are used as return paths for the Baker HVAC system.

\section{Lighting, Water Heating, Appliances}

The natural gas-fueled water heater (located in the garage) has a capacity of 80 gallons and an efficiency factor (EF) of 0.51. Thirty-nine percent of lighting in the home is compact fluorescent lighting (CFL). The home has an ENERGY STAR ${ }^{\circ}$ refrigerator, and a gas range.

\section{Retrofit Measures}

The following retrofits were recommended to the homeowner by the ORNL team.

Table 1: Baker retrofit recommendations

\begin{tabular}{|l|l|}
\hline \multicolumn{1}{|c|}{ Improvement } & \multicolumn{1}{c|}{ Existing condition } \\
\hline $\begin{array}{l}\text { Air sealing (band joists in basement, band joist between first } \\
\text { and second floor, utility penetrations in attic and walls and } \\
\text { basement, first floor flat cathedral vented attic, laundry } \\
\text { room, and attic hatch) }\end{array}$ & $\sim 0.6 \mathrm{ACH}_{\text {natural }}{ }^{a}$ \\
\hline $\begin{array}{l}\text { Insulate basement walls or the framed basement ceiling. } \\
\text { Insulate band joists. }\end{array}$ & None \\
\hline Seal around all windows and doors & R-30 \\
\hline Increase attic insulation to R-50 & $\begin{array}{l}\text { Duct leakage to outside is too large to } \\
\text { measure }\end{array}$ \\
\hline Seal or replace ducts & 7.7 HSPF \\
\hline Replace heating system (9 HSPF) & 10 SEER \\
\hline Replace cooling system (18 SEER) & $0.51 \mathrm{EF}$ gas \\
\hline Replace water heater with heat pump water heater & \\
\hline${ }^{a} \mathrm{ACH}{ }_{\text {natural }}=\mathrm{ACH} 50 / \mathrm{Ncorrected}$, where Ncorrected is the height-corrected LBL "N-factor" \\
(http://www.bpi.org/Web\%20Download/BPI\%20Standards/Building\%20Analyst\%20Professional_2- \\
28-05nNC-newCO.pdf)
\end{tabular}




\section{Envelope}

As can be seen in the recommended retrofit list in Table 1, air sealing and insulating the envelope were at the top of the list. The homeowner chose to tackle the pressure and thermal boundary as well as the HVAC replacement all with the same HVAC contractor. The contractor increased the attic insulation to R-38 with fiberglass batts and insulated the attic knee wall to R19 with fiberglass batts and house wrap installed over the knee wall assembly. The contractor air sealed and insulated the basement band joists to R-22 with R-19 fiberglass batts and R-3 foam board. The basement ceiling was also air sealed. The band joist between the first and second floors, which is accessible by a drop tile ceiling, was insulated with $1 / 2$ in. foam board (R-3) and 1 in. of spray foam (R-6) for a total R-value of R-9. The contractor also caulked the windows. The flat cathedral attic on level 1 needed to be isolated from the conditioned space because the soffit vents were letting in outside air to the space between levels 1 and 3. To isolate this area from the conditioned space, the perimeter was sealed with closed cell foam and R-30 batt insulation was installed on the ceiling of the attic space (see Figure 4). The perimeter between the drop ceiling and the bottom of the floor joists was sealed and insulated with $1 / 2$ to $1 \mathrm{in}$. of closed cell foam.

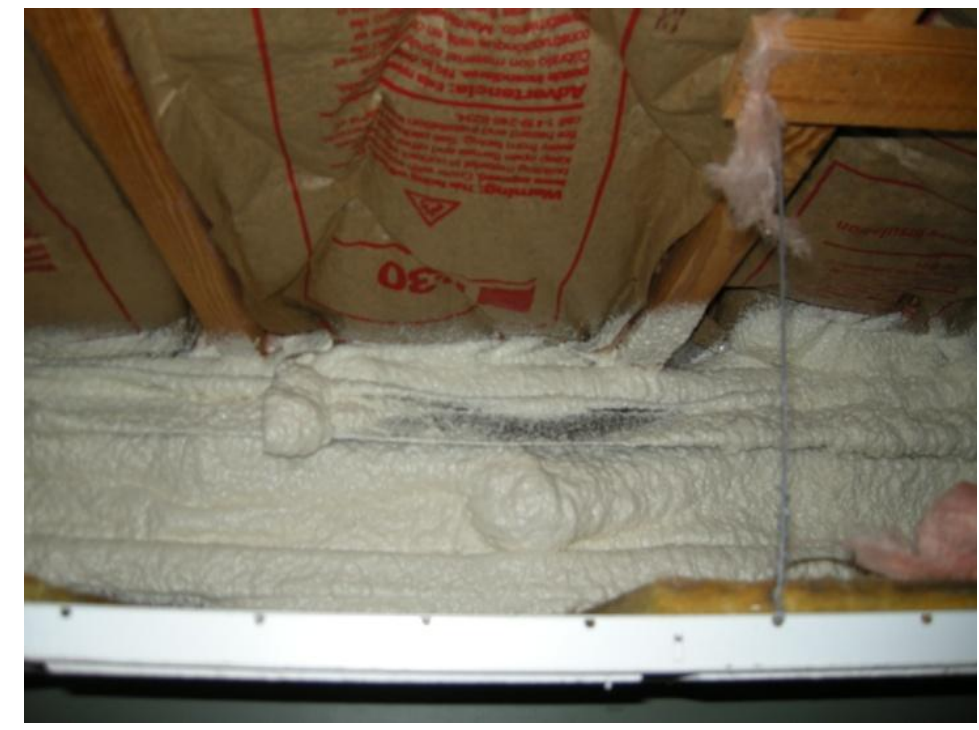

Figure 4: Sealing conditioned space from flat attic on first floor. Spray foam can be seen on the perimeter between the drop ceiling and the flat attic ceiling rafters. Notice the $R-30$ batts between the rafters.

\section{HVAC}

The HVAC was replaced with a 4-ton 16 SEER 9.5 HSPF heat pump with gas backup [90 kBtuh, 95\% annual fuel utilization efficiency (AFUE)]. The supply ducts were replaced in the basement and sealed with mastic in all other accessible places. 


\section{Lighting, Water Heating, Appliances}

The water heater was replaced with a 50-gallon electric heat pump water heater. The efficiency rating of the unit is $2.4 \mathrm{EF}$. No appliance or lighting upgrades were made.

\section{Simulated Energy Savings}

EnergyGauge ${ }^{\circledR}$ software was used to estimate the energy and dollar savings from the installation of the retrofit package. Table 2 shows the estimated energy and energy bill savings and the neutral cash flow for the retrofits. The amortized cost is the yearly payment on a 15-year loan at $7 \%$ interest for the total retrofit cost. The net cost is the yearly loan payment minus the yearly estimated utility cost savings.

Table 2: EnergyGauge ${ }^{\circledR}$ estimated energy and cost savings for retrofits with neutral cash flow analysis

\begin{tabular}{|c|c|c|c|c|c|c|c|}
\hline & $\begin{array}{l}\text { Site } \\
\text { energy } \\
\text { (MMBtu) }\end{array}$ & $\begin{array}{l}\text { Utility } \\
\text { costs } \\
(\$ / y \mathbf{r})\end{array}$ & $\begin{array}{l}\text { Utility } \\
\text { cost } \\
\text { savings } \\
(\$ / y r)\end{array}$ & $\begin{array}{l}\text { Site } \\
\text { energy } \\
\text { savings } \\
\text { (MMBtu) }\end{array}$ & $\begin{array}{l}\text { Total } \\
\text { Retrofit } \\
\text { cost } \\
(\$)\end{array}$ & $\begin{array}{l}\text { Amortized } \\
\text { cost } \\
(\$ / y r)\end{array}$ & $\begin{array}{l}\text { Net cost } \\
(\$ / y r)\end{array}$ \\
\hline $\begin{array}{l}\text { Pre- } \\
\text { retrofit } \\
\text { house }\end{array}$ & 143 & 2,789 & & & & & \\
\hline $\begin{array}{l}\text { Post- } \\
\text { retrofit } \\
\text { house }\end{array}$ & 92.4 & 1,878 & 911 & 50.6 & 14,929 & 1,610 & 699 \\
\hline
\end{tabular}

\section{Diagnostics and Test-Out}

Blower Door tests were done at pre- and post-retrofit conditions and are shown in Table 3. The air infiltration reduction efforts caused a $34 \%$ drop in unwanted airflow and brought the infiltration from 10.3 to $6.8 \mathrm{ACH}_{50}$. Note that the house volume is $45,773 \mathrm{ft}^{3}$.

Table 3: Pre-retrofit and post-retrofit air infiltration diagnostics

\begin{tabular}{|l|c|c|}
\hline Retrofit measure tested & Blower door test result $\left(\mathbf{c f m}_{\mathbf{5 0}} / \mathbf{A C H}_{\mathbf{5 0}}\right)$ & Percent reduction \\
\hline Initial & $7,842 / 10.3$ & \\
\hline Final & $5,168 / 6.77$ & $34 \%$ \\
\hline
\end{tabular}

The impact of replacing the supply ducts in the basement and sealing the other accessible ducts is shown in Table 4. Initially, the duct leakage to the outside was too great to measure. After the retrofits, the duct leakage to the outside was measured to be $144 \mathrm{cfm}_{25}$. As a ratio of the conditioned area served, this is a duct leakage of $2.8 \%$. 
Table 4: Duct leakage test results ${ }^{a}$

\begin{tabular}{|l|c|c|}
\hline & $\mathbf{c f m}_{25}$ & \% Leakage to outside \\
\hline Initial & N/A & N/A \\
\hline Post & 144 & $2.8 \%$ \\
\hline \% Reduction & N/A & N/A \\
\hline
\end{tabular}

${ }^{a}$ Floor area is $5,210 \mathrm{ft}^{2}$.

Overall, the final HERS index improved from 119 to 75. Since the completion of these retrofits, the whole house energy consumption, along with the contribution of major loads such as the airconditioner, water heater, and appliances, has been sub-metered by a Campbell Scientific data logger. Additionally, temperature, humidity, water flow, gas flow, and heat flux on the north and south basement walls are measured.

\section{Baker Costs and Scope of Work}

The retrofit measures described in this report were completed in January 2012, with a total cost of $\$ 14,929$. Table 5 provides a summary of the final scope of work and breakdown of the costs.

Table 5: Baker final scope of work and costs

\begin{tabular}{|c|c|c|c|}
\hline & Pre-retrofit & Post-retrofit & Cost \\
\hline Foundation & $\begin{array}{l}\text { No band joist } \\
\text { insulation }\end{array}$ & $\begin{array}{c}\text { Band joist: R-19 } \\
\text { Air sealed basement ceiling }\end{array}$ & $\$ 730$ \\
\hline Walls & $\begin{array}{l}\text { No band joist } \\
\text { insulation }\end{array}$ & First floor band joist: R-9 & $\$ 727$ \\
\hline Windows & & Air sealed with caulk & $\$ 125$ \\
\hline Doors & & $\begin{array}{l}\text { Weather stripped and sealed } \\
\text { replaced garage and basement } \\
\text { doors with metal units }\end{array}$ & $\$ 939$ \\
\hline Attic/knee walls & $\begin{array}{c}\text { Attic floor: R-30 } \\
\text { Attic knee wall: R-9 }\end{array}$ & $\begin{array}{c}\text { Attic floor: R-38 } \\
\text { Attic knee wall: R-19 } \\
\text { First floor flat attic: R-30 }\end{array}$ & $\$ 1,385$ \\
\hline Cooling & 4-ton 10 SEER & 4-ton 16 SEER heat pump & \\
\hline Heating & $\begin{array}{l}\text { 6.8 HSPF with } \\
\text { hydronic backup }\end{array}$ & $\begin{array}{c}\text { HSPF } 9.5 \text { with } \\
\text { gas backup (90 kBtuh, } \\
95 \% \text { AFUE) }\end{array}$ & $\$ 9,523$ \\
\hline Water heater & $\begin{array}{l}0.51 \mathrm{EF} \text { natural gas } \\
\text { water heater }\end{array}$ & $\begin{array}{l}\text { 2.4 EF electric heat pump } \\
\text { water heater }\end{array}$ & $\$ 1,500$ \\
\hline Total & & & $\$ 14,929$ \\
\hline
\end{tabular}




\section{Country Home Profile}

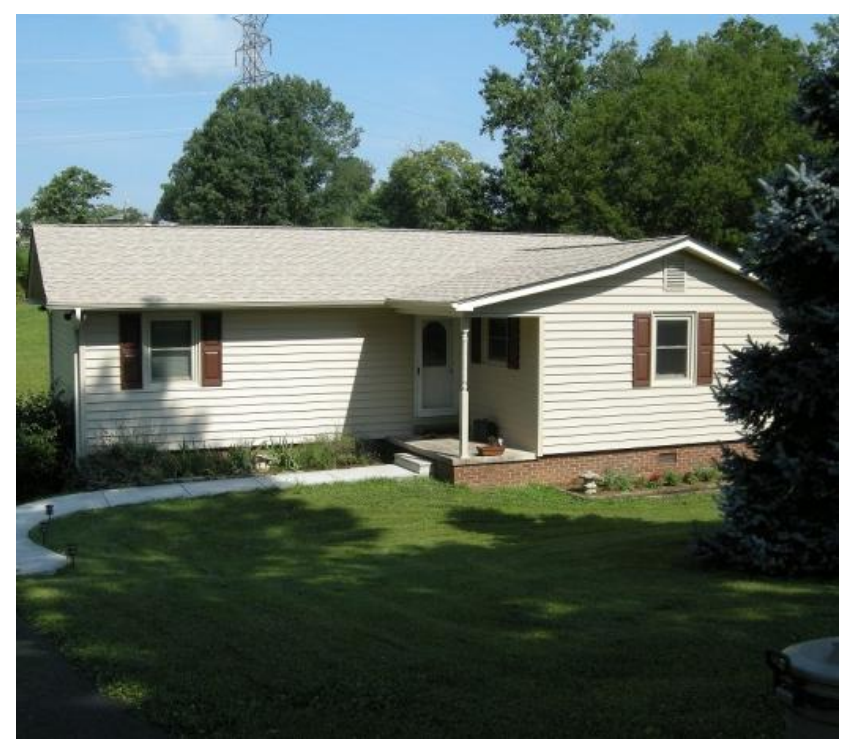

Originally built in the 1970s, Country is a one-story, single-family detached home with 2,448 $\mathrm{ft}^{2}$ of living area. There are four bedrooms and two bathrooms. Country has a vented attic and a finished conditioned basement with a small vented crawlspace. A family of two adults and two teenage children occupy this home. This home is all electric and has no attached garage.

The family's energy costs from January 2009 to December 2009 are shown in Figure 5. With a total annual cost of \$1,605 and annual site energy of $62 \mathrm{MMBtu}(16,190 \mathrm{kWh})$, the family's energy costs are much lower than the average annual site energy consumption for a typical home in the Southeast of this size (116 MMBtu*).

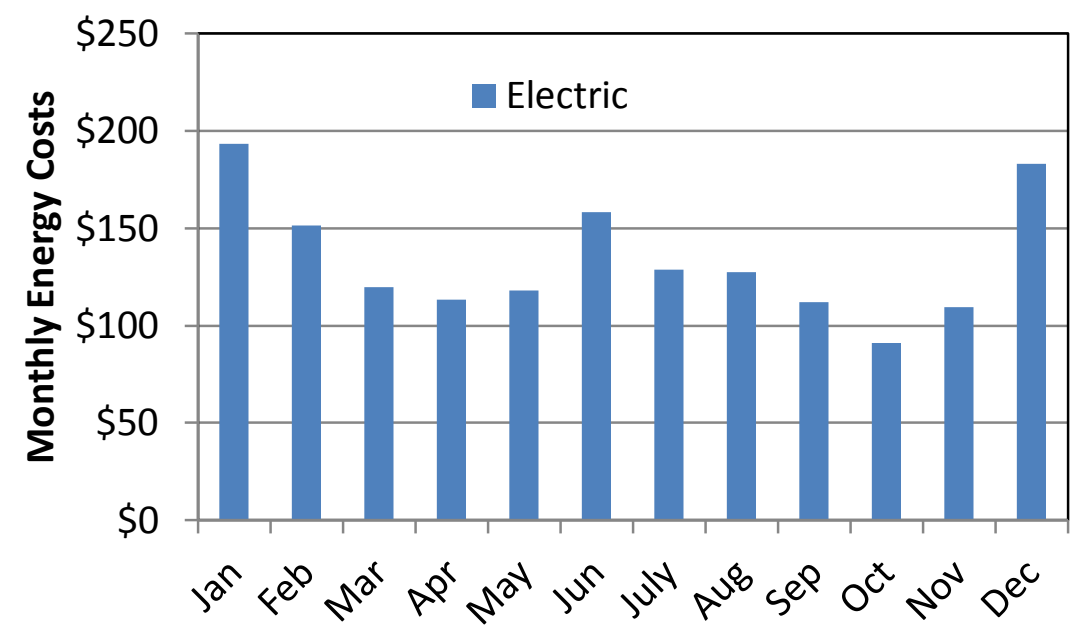

Figure 5: Monthly energy costs for the Country home.

\footnotetext{
${ }^{*}$ Per the 2010 Buildings Energy Data Book, energy consumption for the South Atlantic region is 47.4 kBtu per square foot.
} 
COUNTRY PRE-RETROFIT

CHARACTERISTICS

TYPE: One-story, single-family home

SIZE: $2,448 \mathrm{ft}^{2}$

Occupancy: Two adults, two

teenage children

\section{INITIAL ENVELOPE}

\section{PROFILE}

BASEMENT WALL INSULATION:

R-11

CRAWLSPACE CEILING

INSULATION: R-19

ABOVE GRADE WALL

INSULATION: R-13

ATtiC INSULATION: R-19

KNEE WALL INSULATION: R-13

\section{INITIAL MECHANICAL}

\section{PROFILE}

\section{HVAC}

Location: Exterior, ductwork in basement

Cooling: 2.5 Ton 12 SEER

Heating: 8 HSPF ( 5 kW back-

up electric resistance heat)

WATER HEATERS: 0.91 EF (electric)

\section{INITIAL DIAGNOSTIC}

\section{RESULTS}

HERS: 100

AIR INFILTRATION:

$2,983 \mathrm{cfm}_{50}\left(8.6 \mathrm{ACH}_{50}\right)$

DUCT LEAKAGE TO OUTSIDE:

$568 \mathrm{cfm}_{25}$

DUCT INSULATION: R-4

\section{Country Pre-Retrofit Condition}

\section{Envelope Profile}

Figure 6 shows an illustration of the envelope profile for Country. The basement walls are cinderblock and are framed with 16-in. on center $2 \times 4$ studs with R-11 cavity insulation and covered with drywall. The band joist between the basement and level 1 is not insulated. The crawlspace ceiling has R-19 insulation. The exterior framed walls of level 1 have R-13 insulation and $3 / 4$-in. foam board insulation underneath the vinyl siding cladding. There is a cathedral ceiling in the living room of level 1 , creating a knee wall shown in dark green in Figure 6. The attic is vented and is insulated on the floor to R-19, and the attic knee wall has R-13 insulation.

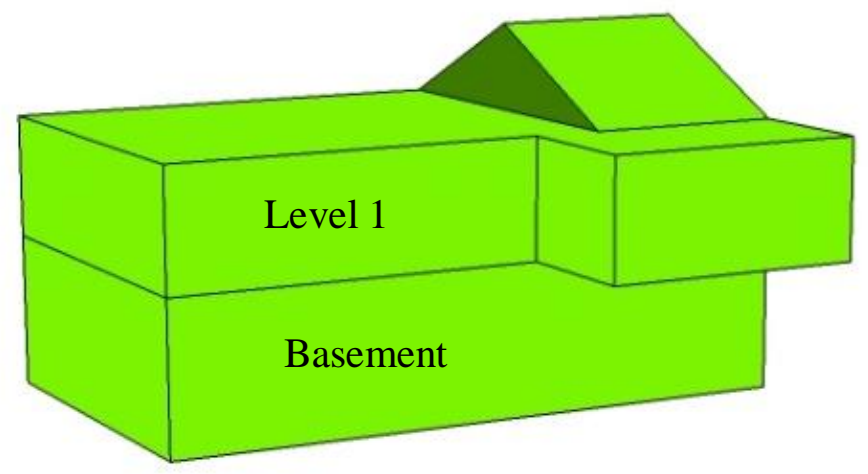

Figure 6: Illustration of Country's building envelope.

Figure 7 shows the uninsulated band joist between the basement and first floor. It is accessible through the drop ceiling in the basement.

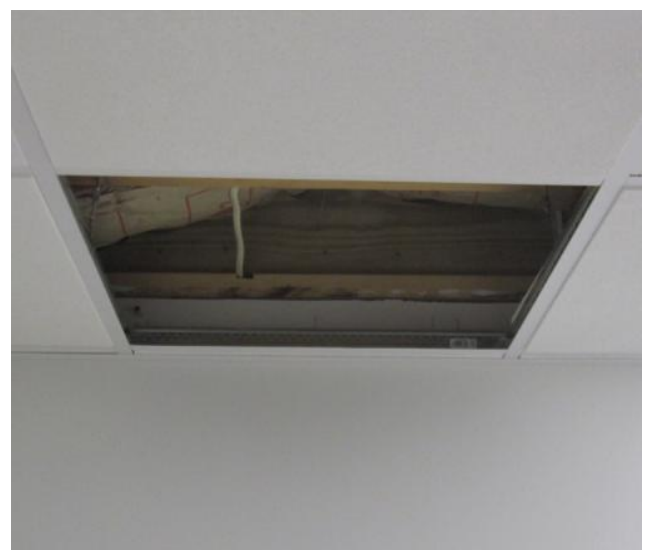

Figure 7: Uninsulated band joist. 
Figure 8 shows the state of the insulation in the crawl space ceiling, which is underneath the kitchen, and the state of the attic insulation. The crawlspace insulation is not performing as it should because much of it has fallen down. The insulation in the attic is about R-19 and should be at least R-38.
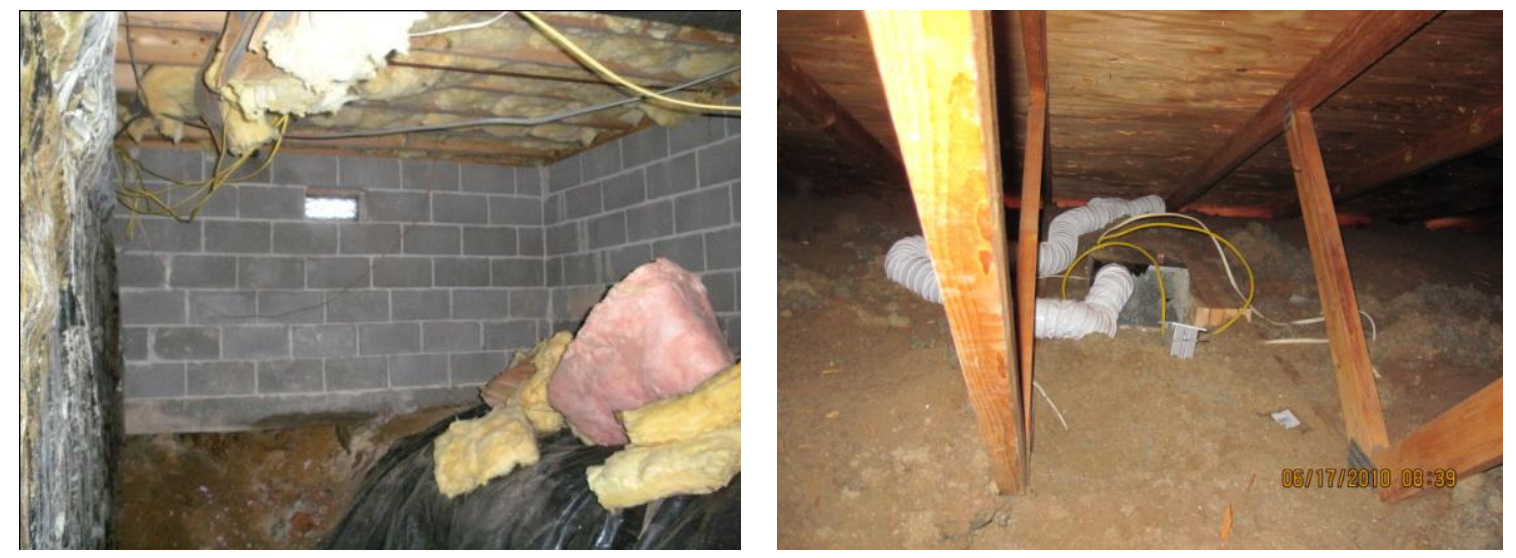

Figure 8: State of insulation in crawl space and attic.

The homeowner had water damage in the cathedral ceiling of the living room. The damage was so bad that the sheetrock and roof decking had to be removed. It was at this time that the homeowner decided to engage in energy retrofits as well.

The windows in the home are single pane with metal frames.

During the initial home energy assessment, a blower door test was conducted to evaluate the air infiltration. The total air leakage rate was $2,983 \mathrm{cfm}_{50}$. With a conditioned volume of $20,774 \mathrm{ft}^{3}$, the air exchange rate for Country was approximately $8.6 \mathrm{ACH}_{50}$.

\section{HVAC}

Conditioned air is provided in Country by one package unit. The unit is a 2.5-ton capacity heat pump, with an efficiency of 12 SEER. The heating efficiency for the heat pump is $8 \mathrm{HSPF}$. The unit is also equipped with a $5 \mathrm{~kW}$ resistance electric backup and is located outside. The ducts are all located in the conditioned space with R-4 insulation. The duct leakage to the outside was measured to be $568 \mathrm{cfm}_{25}$. The normalized duct leakage to the outside amounts to $23 \%$, with respect to the floor area.

\section{Lighting, Water Heating, Appliances}

There is a 50 gallon $0.91 \mathrm{EF}$ electric water heater that is located in the conditioned basement. The house has $100 \%$ incandescent lighting and has no ENERGY STAR® appliances. All the appliances are electric. 


\section{Retrofit Measures}

Table 6 describes the retrofits that were recommended for the Country home by the ORNL team.

Table 6: Country recommended energy-retrofit list

\begin{tabular}{|l|l|}
\hline \multicolumn{1}{|c|}{ Improvement } & \multicolumn{1}{c|}{ Existing condition } \\
\hline Air sealing & $\sim 0.4 \mathrm{ACH}_{\text {natural }}{ }^{\prime}$ \\
\hline Duct seal & $568 \mathrm{cfm}_{25}$ \\
\hline Insulate attic and knee walls, band joist & $\mathrm{R}-19 / \mathrm{R}-13 / \mathrm{None}$ \\
\hline Repair insulation in crawl & $\mathrm{R}-19$ \\
\hline Replace heating system & $8 \mathrm{HSPF}$ \\
\hline Replace cooling system & $12 \mathrm{SEER}$ \\
\hline Replace water heater & 0.91 electric \\
\hline Install energy recovery ventilator & \\
\hline Replace incandescent bulbs with CFL & $100 \%$ incandescent \\
\hline
\end{tabular}

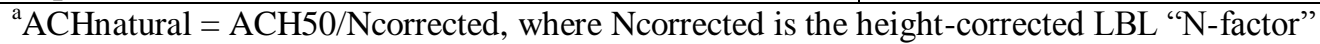

(http://www.bpi.org/Web\%20Download/BPI\%20Standards/Building\%20Analyst\%20Professional_2-

28-05nNC-newCO.pdf)

\section{Envelope}

The first job that was done by the homeowner was repairing the cathedral ceiling in the living room. The drywall and roof decking had to be removed. The cathedral ceiling and the $2 \times 6$ kitchen walls were sealed with 2 in. of closed cell spray foam, and then R-13 batts were installed for a final R-value of about R-24 (Figure 9). The attic floor was sealed and fiberglass insulation was blown in for a resulting insulation value of R-50. The crawlspace ceiling was flashed with spray foam.
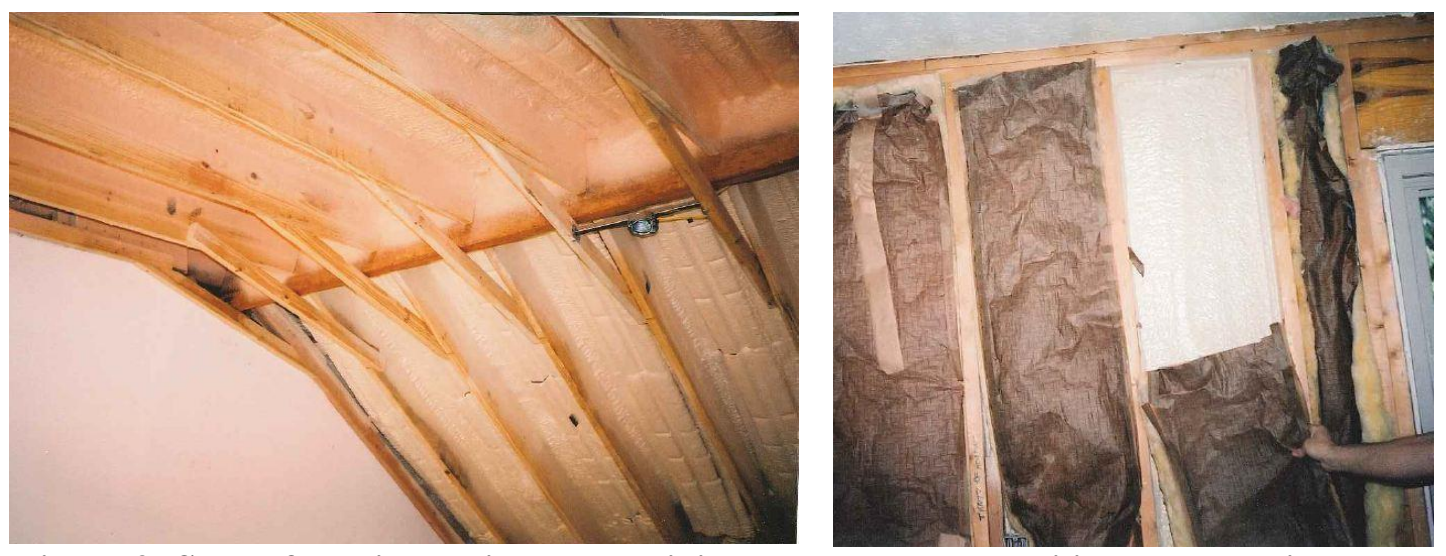

Figure 9: Spray foam insulation on the living room cathedral ceiling and the kitchen walls.

The existing R-19 batt insulation in the attic knee wall was repaired, and then 2 in. of foam board (R-10) was laid on top of the knee wall studs. On top of the foam board about $1 / 2 \mathrm{in}$. of closed cell spray foam (R-3) was applied (Figure 10). Penetrations in the basement and crawl space walls were sealed, and the band joist was sealed and insulated. For the basement band joist, 2 in. of foam board with $1 \mathrm{in}$. of closed cell spray foam was used for a resulting R-16. For the crawlspace band joist, 2 in. of foam board with 2 in. of closed cell spray foam was used for a resulting R-22. 


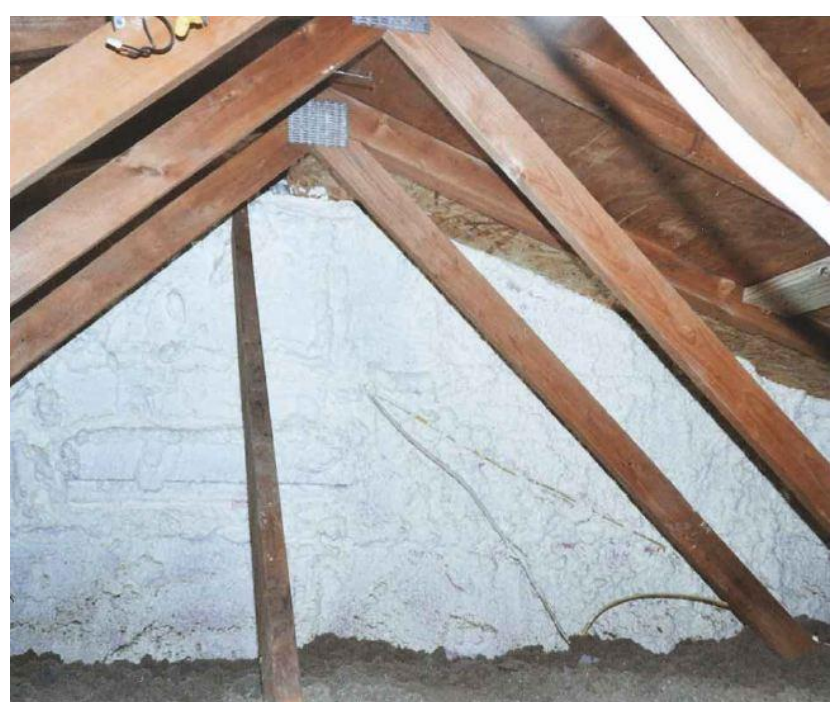

Figure 10: Attic knee wall with spray foam.

The exterior walls that were not accessible (as the kitchen walls were) were insulated using a drill and fill method with an open/closed cell hybrid foam insulation (Figure 11). It is difficult to determine the resulting $\mathrm{R}$-value of this method, but it is estimated the new cavity insulation was increased to R-14. According to the manufacturer, when the product is applied to a wall with existing insulation, the product mostly increases the air tightness of the wall rather than increasing the R-value. New siding was also installed on the home. After the old siding was removed $3 / 4$ - in. foam board (R-4) was found on the home. The new aluminum siding that was installed had $1.5 \mathrm{in}$. of form-fitting insulation (R-5.3). The windows of the home were replaced with units with a U-factor of 0.3 and a solar heat gain coefficient (SHGC) of 0.2.

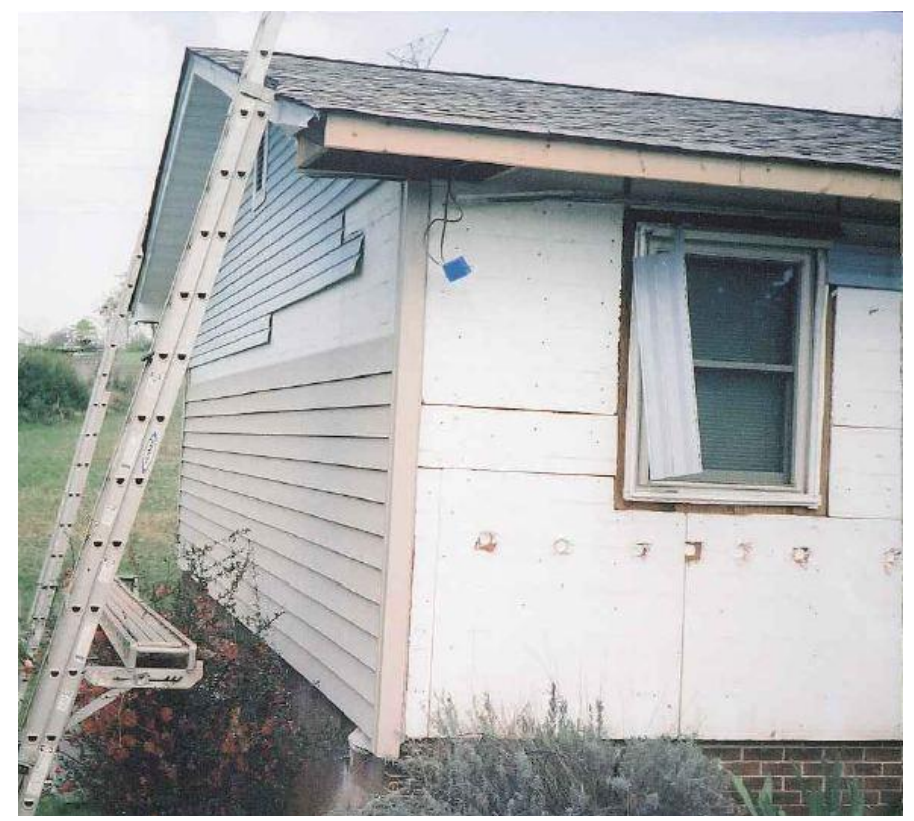

Figure 11: Holes can be seen in the exposed wall were the foam was injected into the wall space. The existing foam board insulation can also be seen. 


\section{HVAC}

The package heat pump unit was replaced with a split unit with a capacity of 3 tons and an efficiency of 19 SEER and 9 HSPF. The condenser was placed outside, and the heater coils, evaporator, and blower are inside the basement. Figure 12 shows the old and new units for comparison. The ductwork was sealed.
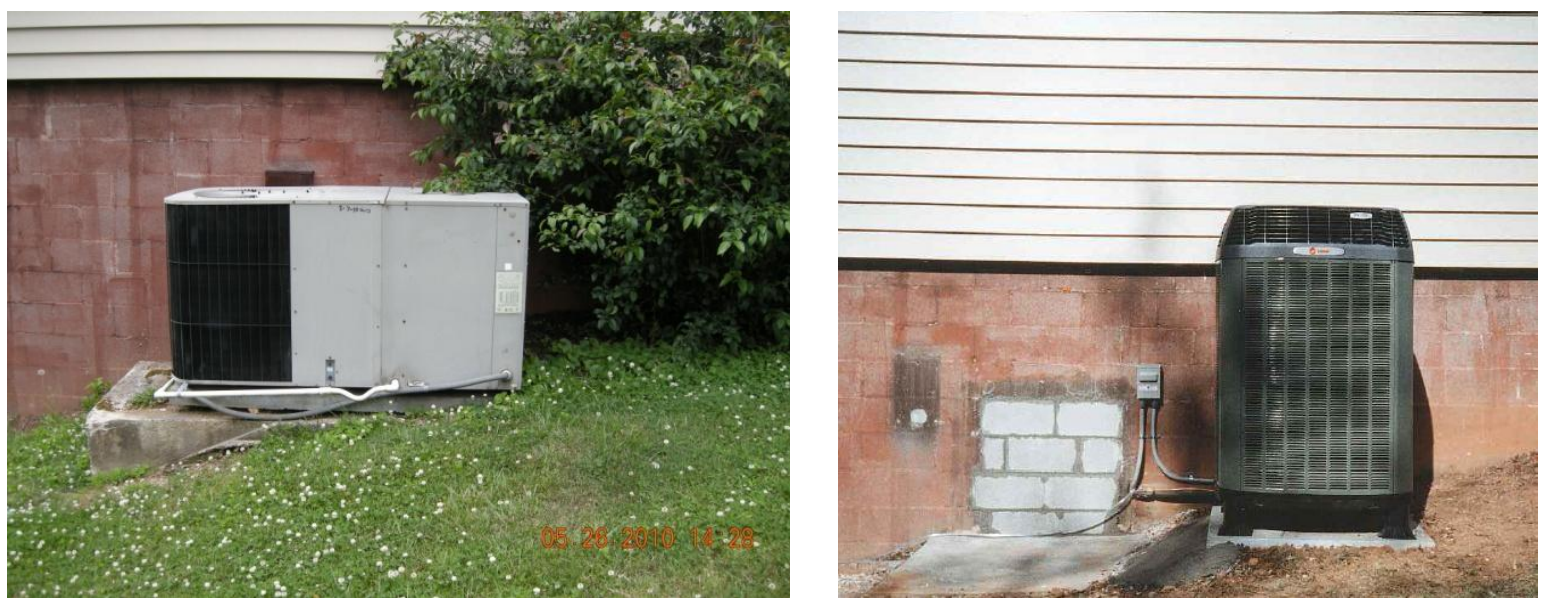

Figure 12: The old and new heat pump units.

\section{Lighting, Water Heating, Appliances}

The lighting in the home was upgraded to $96 \% \mathrm{CFL}$. The electric water heater was replaced with a 2.4 EF electric heat pump water heater. The refrigerator was upgraded to an ENERGY STAR ${ }^{\circledR}$ unit.

\section{Simulated Energy Savings}

EnergyGauge ${ }^{\circledR}$ software was used to estimate the energy and dollar savings from the installation of the retrofit package. Table 7 shows the estimated energy and energy bill savings and the neutral cash flow for the retrofits. The amortized cost is the yearly payment on a 15-year loan at $7 \%$ interest for the total retrofit cost. The net cost is the yearly loan payment minus the yearly estimated utility cost savings.

Table 7: EnergyGauge ${ }^{\circledR}$ estimated energy and cost savings for retrofits with neutral cash flow analysis

\begin{tabular}{|c|c|c|c|c|c|c|c|}
\hline & $\begin{array}{c}\text { Site } \\
\text { energy } \\
\text { (MMBtu) }\end{array}$ & $\begin{array}{l}\text { Utility } \\
\text { cost } \\
(\$ / y r)\end{array}$ & $\begin{array}{l}\text { Utility } \\
\text { cost } \\
\text { savings } \\
(\$ / y r)\end{array}$ & $\begin{array}{l}\text { Site } \\
\text { energy } \\
\text { savings } \\
\text { (MMBtu) }\end{array}$ & $\begin{array}{l}\text { Total } \\
\text { Retrofit } \\
\text { cost } \\
(\$)\end{array}$ & $\begin{array}{l}\text { Amortized } \\
\text { cost } \\
(\$ / y r)\end{array}$ & $\begin{array}{l}\text { Net } \\
\text { cost } \\
(\$ / y r)\end{array}$ \\
\hline $\begin{array}{l}\text { Pre- } \\
\text { retrofit } \\
\text { house }\end{array}$ & 74.1 & 1,924 & & & & & \\
\hline $\begin{array}{l}\text { Post- } \\
\text { retrofit } \\
\text { house }\end{array}$ & 40.6 & 1,054 & 870 & 33.5 & 23,835 & 2,571 & 1,701 \\
\hline
\end{tabular}




\section{Diagnostics and Test-Out}

Blower door tests were completed at different intervals during the retrofit process. This practice aids in determining which retrofits were the most successful in decreasing the air-infiltration. The test results at these intervals are shown in Table 8 in the order they were completed. As seen in the table the best step was general air sealing involving sealing the air pathways between the living space and the attic. This step resulted in a decrease of infiltrating air by $32 \%$.

Table 8: Air infiltration diagnostics during the retrofit

\begin{tabular}{|l|l|l|}
\hline Retrofit measure tested & $\begin{array}{l}\text { Blower door } \\
\text { test result } \\
\text { (cfm50/ACH50) }\end{array}$ & $\begin{array}{l}\text { Percent } \\
\text { reduction }\end{array}$ \\
\hline $\begin{array}{l}\text { Initial (already installed new } \\
\text { windows, foamed walls, siding, } \\
\text { and foamed cathedral ceiling) }\end{array}$ & $2,983 / 8.6$ & 32 \\
\hline $\begin{array}{l}\text { Sealed band joist, sealed attic knee } \\
\text { wall, can lights, attic access, top } \\
\text { plates, etc. }\end{array}$ & $2,031 / 5.9$ & 10 \\
\hline $\begin{array}{l}\text { Package heat pump replaced with } \\
\text { split heat pump (sealed large hole } \\
\text { that ducts went through to outside } \\
\text { package unit) and completed spot } \\
\text { air-sealing }\end{array}$ & $1,731 / 5.0$ & 42 \\
\hline Final & $1,731 / 5.0$ & \\
\hline
\end{tabular}

${ }^{a}$ Percent reduction is determined by evaluating the cfm50 reduction for each of the retrofit measures as a ratio of the total building infiltration.

Overall the final HERS index improved from 100 to 66. Since the completion of these retrofits, the whole house energy consumption, along with the contribution of major loads such as the airconditioner, water heater, and appliances, has been sub-metered by a Campbell Scientific data logger. Additionally, temperature, humidity, and water flow are measured.

The post-retrofit duct leakage is shown in Table 9. Initially, the duct leakage to the outside was $568 \mathrm{cfm}_{25}$. After retrofits, the duct leakage to the outside was measured to be $163 \mathrm{cfm}_{25}$; this is a $71 \%$ decrease. As a ratio of the conditioned area served, this is a duct leakage of $6.7 \%$.

Table 9: Duct leakage test results ${ }^{a}$

\begin{tabular}{|c|c|c|}
\hline & $\mathbf{c f m}_{\mathbf{2 5}}$ & \% Leakage to outside \\
\hline Initial & 568 & $23 \%$ \\
\hline Post & 163 & $6.7 \%$ \\
\hline \% Reduction & $71 \%$ & $71 \%$ \\
\hline
\end{tabular}




\section{Country Costs and Scope of Work}

The retrofit measures described in this report were completed in April 2011, with a total cost of about $\$ 23,835$. A breakdown of the cost is presented in Table 10 .

Table 10: Country final scope of work and breakdown of the costs

An asterisk following the cost of a retrofit indicates that this cost is an estimate based on data found at http://www.nrel.gov/ap/retrofits/group_listing.cfm

\begin{tabular}{|c|c|c|c|}
\hline Country & Pre-retrofit & Post-retrofit & Cost of retrofit \\
\hline Foundation & $\begin{array}{l}\text { Finished conditioned } \\
\text { basement/vented } \\
\text { crawlspace }\end{array}$ & $\begin{array}{l}\text { Basement band joist: R-16 } \\
\text { Crawlspace band joist: R-22 }\end{array}$ & $\$ 852$ \\
\hline Walls & $\begin{array}{c}\text { Cavity:R-13 } \\
\text { Insulated sheating:R-4 }\end{array}$ & $\begin{array}{c}\text { Kitchen walls cavity: R-16 } \\
\text { Other exterior wall cavity: R-14 } \\
\text { Exterior insulating sheathing: R-9.3 }\end{array}$ & $\$ 5,157$ \\
\hline Windows & $\begin{array}{l}\text { Metal frame, single } \\
\text { pane }\end{array}$ & Windows U-Factor 0.3 SHGC 0.2 & $\$ 4,160$ \\
\hline Attic/knee walls & $\begin{array}{c}\text { Attic floor: R-19 } \\
\text { Knee wall cavity: } \mathrm{R}-13\end{array}$ & $\begin{array}{c}\text { Attic floor: R-50 } \\
\text { Knee wall cavity: R-19 } \\
\text { Knee wall sheathing: R-13 }\end{array}$ & $\$ 1,605$ \\
\hline Cooling & $\begin{array}{l}\text { 2.5-Ton } 12 \text { SEER HP } \\
\text { Package Unit with } \\
\text { 5-kW electric backup }\end{array}$ & 3-ton 19 SEER Heat Pump & \multirow[t]{2}{*}{$\$ 8,705$} \\
\hline Heating & $8 \mathrm{HSPF}$ & HSPF 9 & \\
\hline Water heater & $\begin{array}{c}0.91 \mathrm{EF} \text { electric } \\
\text { resistance water heater }\end{array}$ & $\begin{array}{l}\text { 2.4 EF electric heat pump water } \\
\text { heater }\end{array}$ & $\$ 2,100^{*}$ \\
\hline Lighting & $100 \%$ incandescent & $96 \% \mathrm{CFL}$ & $\$ 276 *$ \\
\hline Appliances & $\begin{array}{c}\text { Non-ENERGY } \\
\text { STAR® appliances }\end{array}$ & ENERGY STAR $®$ refrigerator & $\$ 980 *$ \\
\hline Total & & & $\$ 23,835$ \\
\hline
\end{tabular}




\section{Summit Home Profile}

Built in the 1990s, Summit is a twostory, single-family detached home with $3,110 \mathrm{ft}^{2}$ of living area. The first floor has a living area of $1,136 \mathrm{ft}^{2}$, while the second floor has $987 \mathrm{ft}^{2}$, and the conditioned basement is $987 \mathrm{ft}^{2}$. Summit is home to a family of two adults. The home has three bedrooms and two and a half bathrooms. Summit has a traditional vented attic and an unfinished conditioned basement and small vented crawlspace. The home also has an attached garage.

Figure 13 shows the energy costs of the Summit house from January 2009 to December 2009. The total energy costs were \$2,223 (126 MMBtu of site

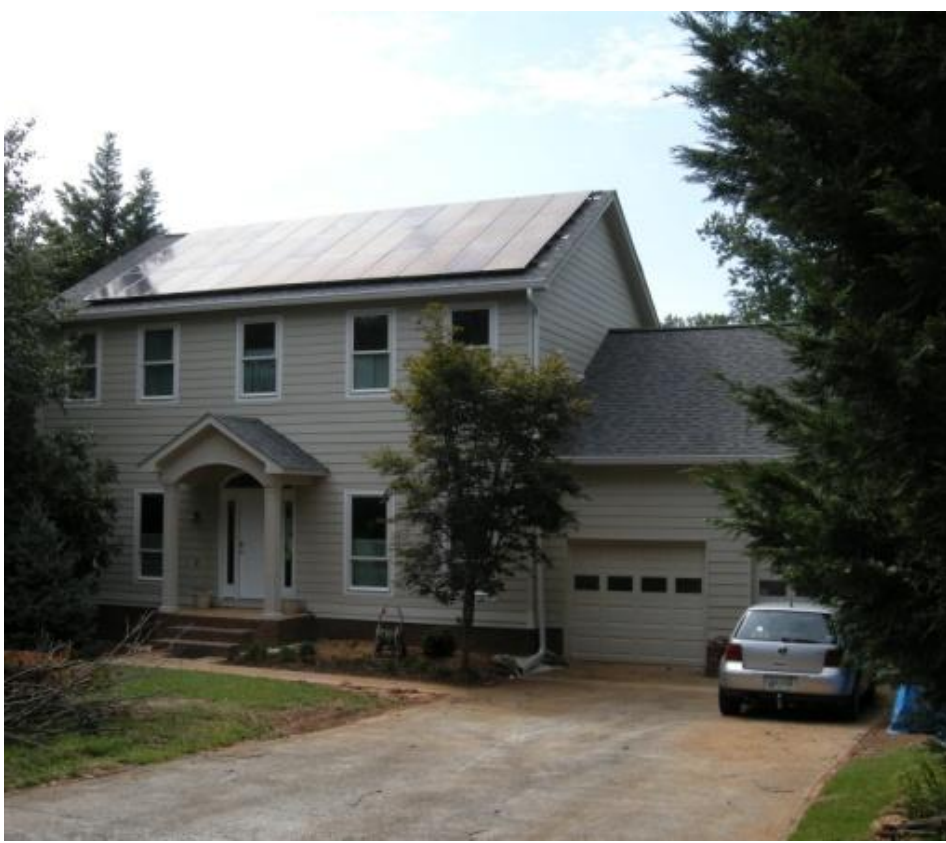
energy). In contrast, a typical home in the Southeast of this size is expected to have an average annual site energy consumption of 147 MMBtu.* Hence, the energy costs are slightly lower than the average home of this size in the area. The homeowners were planning to renovate the house before retiring and attended a presentation describing energy retrofits. After the presentation, the scope of the project changed and they decided to proceed with deep energy retrofits while renovating, chasing after a net-zero energy home.

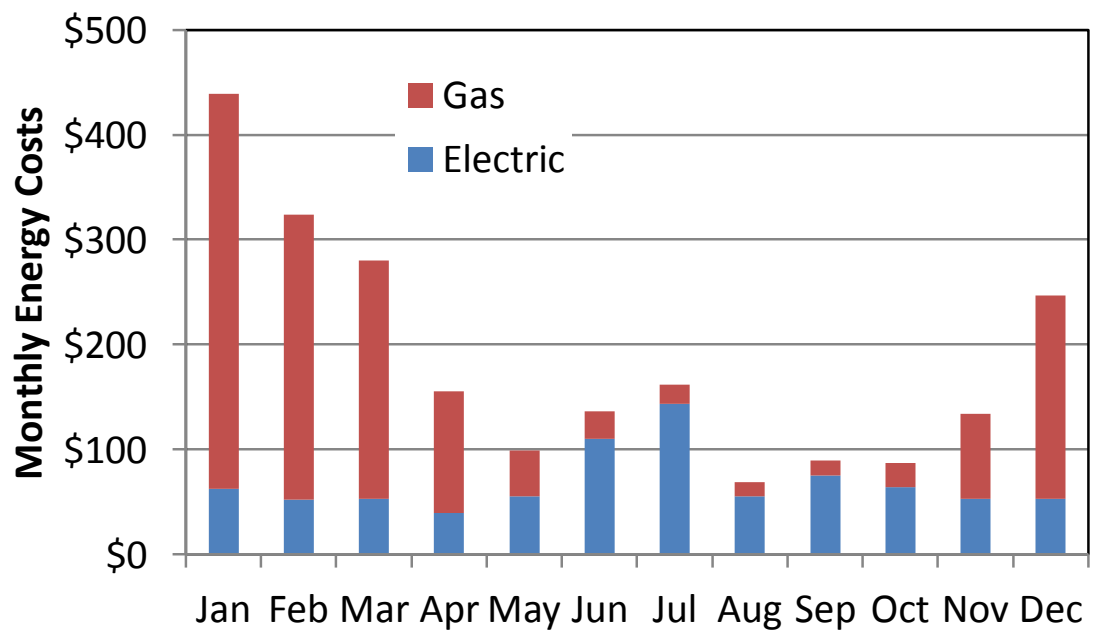

Figure 13: Summit monthly energy costs.

\footnotetext{
*Per the 2010 Buildings Energy Data Book, energy consumption for the South Atlantic region is 47.4 kBtu per square foot.
} 
SUMMIT PRE-RETROFIT

\section{CHARACTERISTICS}

TYPE: Two-story, single-family

home

SIZE: $3110 \mathrm{ft}^{2}$

Occupancy: Two adults

\section{INITIAL ENVELOPE}

\section{Profile}

BASEMENT WALL

INSULATION: None

BASEMENT/CRAWLSPACE

CEILING INSULATION: NONE

WALL INSULATION: R-13

BAND-JOIST INSULATION: None

ATTIC InSULATION: R-25 to

R-35

KNEE WALL INSULATION: NONE

\section{INITIAL MECHANICAL}

\section{PROFILE}

MAIN ZONE (BASEMENT AND

LEVEL 1):

Location: Conditioned

basement

Cooling: 3-ton 13 SEER AC

Heating: 64 kBtuh 75\% AFUE

\section{LEVEL 2 ZONE}

Location: Attic

Cooling: 2-ton 13 SEER AC

Heating: 64 kBtuh 75 AFUE

WATER HEATER: $0.51 \mathrm{EF}$

$\underline{\text { (natural gas) }}$

\section{INITIAL DIAGNOSTIC}

\section{RESULTS}

HERS: 119

AIR INFILTRATION:

$4,011 \mathrm{cfm}_{50}\left(9.1 \mathrm{ACH}_{50}\right)$

DUCT LEAKAGE TO OUTSIDE:

$1^{\text {st }}$ floor: $0 \mathrm{cfm}_{25}$

$2^{\text {nd }}$ floor: $88 \mathrm{cfm}_{25}$

DUCT INSULATION: R-4

\section{Summit Pre-Retrofit Condition}

\section{Envelope Profile}

The building envelope of the Summit house is bounded below by a basement and a vented crawlspace under the office behind the garage. The basement walls and ceiling have no insulation. The crawlspace ceiling also does not have any insulation. Level 1 and 2 exterior walls have R-13 insulation except the level 1 walls adjacent to the garage, which have no cavity insulation. The vented attic has an average of R-30 insulation on the floor. The attic knee wall has no insulation. The interior ceiling height for this home is $8 \mathrm{ft}$ for both the first and second level, and $9.5 \mathrm{ft}$ for the basement. Shown in Figure 14 is an illustration of the home's envelope profile. The dark green colors represent the attic knee wall.

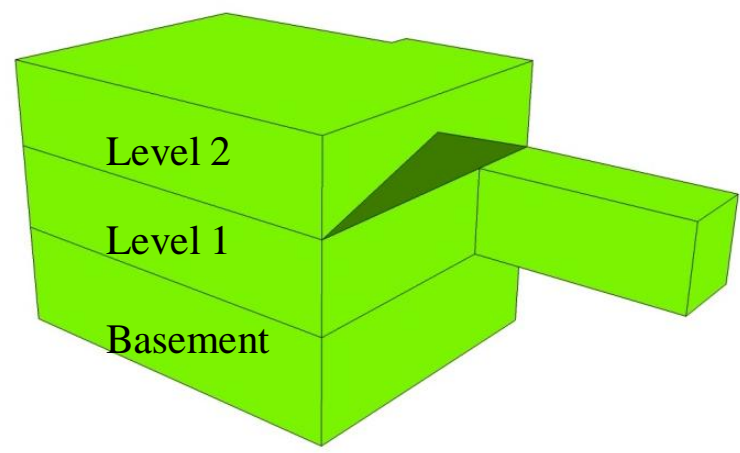

Figure 14: Illustration of Summit's building profile.

The windows of the home are double pane with vinyl frames (U-0.46, SHGC - 0.57). There is no external band joist insulation (this was determined when the siding was replaced during the retrofit).

During the initial home energy assessment, a blower door test was conducted to evaluate the air infiltration. The total air leakage rate was $4,011 \mathrm{cfm}_{50}$. With a conditioned volume of $26,364 \mathrm{ft}^{3}$, the air exchange rate for Summit was approximately $9.1 \mathrm{ACH}_{50}$.

\section{HVAC}

Conditioned air is provided in Summit by two HVAC systems. The main zone which includes the basement and level 1 is serviced by a 3-ton air conditioner, with an efficiency of 13 SEER located in the conditioned basement. Also located in the basement is the main zone gas furnace, which has a capacity of $64 \mathrm{kBtuh}$ and an efficiency rating of $75 \%$ AFUE. The level 2 zone HVAC system is located in the attic. The air conditioner has a 2 -ton capacity and a 13 SEER rating. Similar to the main zone unit, the gas furnace has a capacity of $64 \mathrm{kBtuh}$ and a rating of $75 \%$ AFUE. 
The ducts for the main zone HVAC system are located in the conditioned basement - all within the pressure/thermal envelope. The ductwork has R-4 insulation, and after testing, this system was determined to have a duct leakage to the outside of $0 \mathrm{cfm}_{25}$. The ducts for the level 2 zone HVAC system are located in the attic. Similar to the first ducts, R-4 insulation was used on the flex ducts. A duct leakage test revealed $88 \mathrm{cfm}_{25}$ of leakage. This is equal to $8.9 \%$ of the floor area $\left(987 \mathrm{ft}^{2}\right)$ served by this system.

\section{Lighting, Water Heating, Appliances}

The natural gas water heater is located in the basement. It has a storage capacity of 40 gallons and is rated at $0.51 \mathrm{EF}$. The house has 5\% CFL lighting and no ENERGY STAR® appliances. Both the range and oven are electric.

\section{Retrofit Measures}

The following retrofit measures were suggested to the homeowners by the ORNL team.

Table 11: Summit retrofit list

\begin{tabular}{|l|l|}
\hline Improvement & Existing condition \\
\hline Air sealing (attic floor, band joists) & $0.52 \mathrm{ACH}_{\text {natural }}{ }^{a}$ \\
\hline $\begin{array}{l}\text { Insulate (add } 1 \text { in. of foam extruded polystyrene } \\
\text { sheathing to basement walls, insulate band joist in } \\
\text { basement, and add insulation to attic floor) }\end{array}$ & R-30 in attic \\
\hline Replace siding and add 2 in. of foam underneath & None \\
\hline Replace windows with low-e triple pane & Double pane \\
\hline $\begin{array}{l}\text { Replace HVAC System with 2-zoned single unit, } \\
\text { Install energy recovery ventilator }\end{array}$ & 13 SEER \\
\hline Add PV (2-2.5 kW peak $)$ & $75 \%$ AFUE \\
\hline $\begin{array}{l}{ }^{a} \text { ACHnatural = ACH50/Ncorrected, where Ncorrected is the height-corrected LBL "N-factor" } \\
\text { (http://www.bpi.org/Web\%20Download/BPI\%20Standards/Building\%20Analyst\%20Professional_2- }\end{array}$ \\
28-05nNC-newCO.pdf)
\end{tabular}

\section{Envelope}

The homeowners of the Summit house exceeded the recommended retrofits in many cases. The attic was vacuumed of the old insulation and the entire attic floor was sealed with pink latex foam (as seen in Figure 15) and then fiberglass insulation was blown in to R-60. The attic knee wall was sealed with an air barrier wrap, and insulated with 2-in.-thick foam panels to R-10. The walls between the home and garage were found to have no insulation. The drywall was removed on the garage adjacent walls, and they were sealed and then fiberglass batts (R-19) were installed in the wall cavities. Then 2 in. of foam panels (R-10) were installed before the drywall was reinstalled on top of the foam. Before the new siding was installed, 1/2-in.-thick structural insulated sheathing (R-2.74) was installed. The band joist between the basement and first floor was sealed and insulated to R-10. The crawlspace walls were insulated with fiberglass batts to R10. The south facing basement wall, the only framed non-block wall in the basement, was sealed with latex foam and then insulated to R-19. The above-grade portion of the block basement wall was insulated on the outside with 2-in. extruded polystyrene foam panels (R-10) covered in 1/2-in. thin-brick veneer, as shown in Figure 16. The windows were replaced with units of U-factor 0.2 (0.1 for quad pane window installed in living room) and SFGC of 0.35 . 


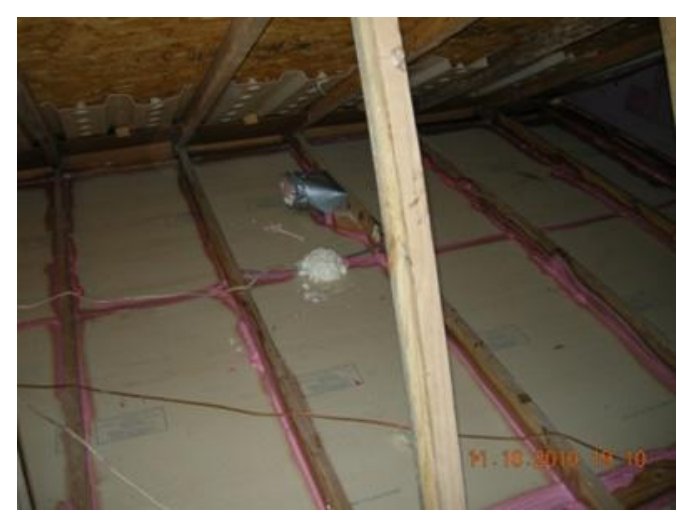

Figure 15: Pink latex foam sealing the attic floor.

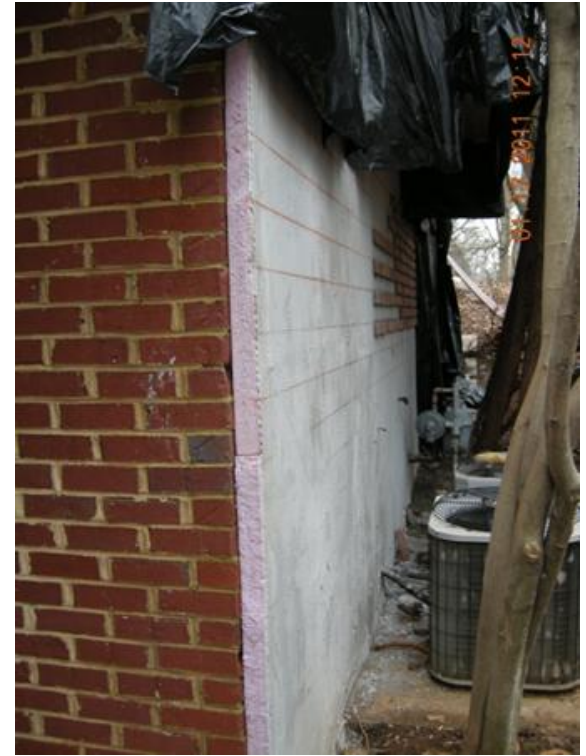

Figure 16: Above-grade basement walls shown during retrofit with foam board and the thin brick veneer being installed.

The windows were replaced with triple and quad pane units with U-0.2 and U-0.1 (for quad pane units) and SHGC of 0.35 .

\section{HVAC}

The air-conditioning units were replaced with two variable-speed multi-split heat pumps, both with a capacity of 4 tons and efficiency ratings of 15 SEER and 8.7 HSPF. Each one of these units run four mini-split units throughout the house. Because this system was installed, the duct work is no longer used.

\section{Lighting, Water Heating, Appliances}

The water heater was not upgraded. The refrigerator was upgraded to an ENERGY STAR® unit. The homeowners installed an $8.5 \mathrm{~kW}_{\text {peak }}$ photovoltaic system on the south facing roof of their home. The lighting was converted to $100 \%$ energy efficient lighting, with mostly CFLs but some LEDs.

\section{Simulated Energy Savings}

EnergyGauge ${ }^{\circledR}$ software was used to estimate the energy and dollar savings from the installation of the retrofit package. Table 12 shows the estimated energy and energy bill savings and the neutral cash flow for the retrofits. The amortized cost is the yearly payment on a 15-year loan at $7 \%$ interest for the total retrofit cost. The net cost is the yearly loan payment minus the yearly estimated utility cost savings. Without taking into account PV generation, Summit would have a post-retrofit energy consumption of $59 \mathrm{MMBtu}$ and a total cost of $\$ 52,698$. 
Table 12: EnergyGauge ${ }^{\circledR}$ estimated energy and cost savings for retrofits with neutral cash flow analysis

\begin{tabular}{|c|c|c|c|c|c|c|c|}
\hline & $\begin{array}{l}\text { Site } \\
\text { energy } \\
\text { (MMBtu) }\end{array}$ & $\begin{array}{l}\text { Utility } \\
\text { cost } \\
(\$ / \mathbf{y r})\end{array}$ & $\begin{array}{l}\text { Utility } \\
\text { cost } \\
\text { savings } \\
(\$ / y r)\end{array}$ & $\begin{array}{l}\text { Site } \\
\text { energy } \\
\text { savings } \\
\text { (MMBtu) }\end{array}$ & $\begin{array}{l}\text { Total } \\
\text { Retrofit } \\
\text { cost } \\
(\$)\end{array}$ & $\begin{array}{l}\text { Amortized } \\
\text { cost } \\
(\$ / y r)\end{array}$ & $\begin{array}{l}\text { Net cost } \\
(\$ / y r)\end{array}$ \\
\hline $\begin{array}{l}\text { Pre- } \\
\text { retrofit } \\
\text { house }\end{array}$ & 156.8 & 2,315 & & & & & \\
\hline $\begin{array}{l}\text { Post- } \\
\text { retrofit } \\
\text { house }\end{array}$ & 22 & 337 & 1,978 & 134.8 & 86,873 & 9,370 & 7,392 \\
\hline
\end{tabular}

\section{Diagnostics and Test-Out}

The post-retrofit blower door test yielded $1,691 \mathrm{cfm}_{50}$ of infiltrating air. This is a $58 \%$ reduction in infiltration, as Table 13 shows.

Table 13: Pre-retrofit and post-retrofit air infiltration diagnostics

\begin{tabular}{|l|l|l|}
\hline $\begin{array}{l}\text { Retrofit } \\
\text { measure tested }\end{array}$ & $\begin{array}{l}\text { Blower door test } \\
\text { result } \\
(\mathbf{c f m 5 0 / A C H 5 0 )}\end{array}$ & Percent reduction $^{a}$ \\
\hline Initial & $4,011 / 9.1$ & \\
\hline Final & $1,691 / 3.85$ & 58 \\
\hline
\end{tabular}

${ }^{a}$ Percent reduction is determined by evaluating the cfm50 reduction for each of the retrofit measures as a ratio of the total building infiltration.

The ductwork is no longer used in Summit because ductless mini-splits were installed.

Overall the final HERS index improved from 119 to 23 (including solar generation) or 69 (without solar generation). Since the completion of these retrofits, the whole house energy consumption, along with the contribution of major loads such as the air-conditioner, water heater, and appliances have been sub-metered by a Campbell Scientific data logger.

Additionally, temperature, humidity, water flow, gas flow, and heat flux on the south basement wall are measured.

\section{Summit Cost and Scope of Work}

The retrofit measures described in this report were completed in July 2011, with a total cost of about $\$ 86,873$. Table 14 provides a summary of the final scope of work and breakdown of the costs. The cost for the PV includes a $30 \%$ tax incentive. 
Table 14: Summit final scope of work and costs

An asterisk following the cost of a retrofit indicates that this cost is an estimate based on data found at http://www.nrel.gov/ap/retrofits/group_listing.cfm

\begin{tabular}{|c|c|c|c|}
\hline Summit & Pre-retrofit & Post-retrofit & Cost \\
\hline Foundation & Uninsulated basement walls & $\begin{array}{l}\text { Above-grade exterior } \\
\text { insulation }\end{array}$ & $\$ 10,691$ \\
\hline Walls & $\mathrm{R}-13$ & $\begin{array}{l}\text { Added R-3 sheathing to } \\
\text { all exterior walls, improved } \\
\text { walls adjacent to garage } \\
\text { to R-19 (cavity) and R-10 } \\
\text { (sheathing) }\end{array}$ & $\$ 5,178$ \\
\hline Windows & double pane vinyl & $\begin{array}{l}\text { Triple and quad pane (U- } \\
0.1-0.2 ; \text { SHGC }-0.35)\end{array}$ & $\$ 16,363$ \\
\hline Attic/Knee walls & $\begin{array}{l}\text { R-38 in attic, No insulation on } \\
\text { knee wall }\end{array}$ & $\begin{array}{l}\text { R-60 attic insulation, } \mathrm{R}-10 \\
\text { on knee wall }\end{array}$ & $\$ 6,311$ \\
\hline Cooling & 5-ton (3-ton/2-ton) 13 SEER & $\begin{array}{l}\text { Two 4-ton multi split heat } \\
\text { pumps (15 SEER) }\end{array}$ & \multirow{2}{*}{$\$ 12,739$} \\
\hline Heating & $\begin{array}{c}\text { 64-kBtuh gas furnace } 75 \% \\
\text { AFUE }\end{array}$ & 8.7 HSPF & \\
\hline Refrigerator & non-ENERGY STAR® & ENERGY STAR® & $\$ 980 *$ \\
\hline Lighting & $5 \% \mathrm{CFL}$ & $100 \% \mathrm{CFL}$ & $\$ 436^{*}$ \\
\hline Solar PV system & None & $8.5 \mathrm{~kW}$ peak & $\$ 34,175$ \\
\hline Total & & & $\$ 86,873$ \\
\hline
\end{tabular}




\section{Gaiter Home Profile}

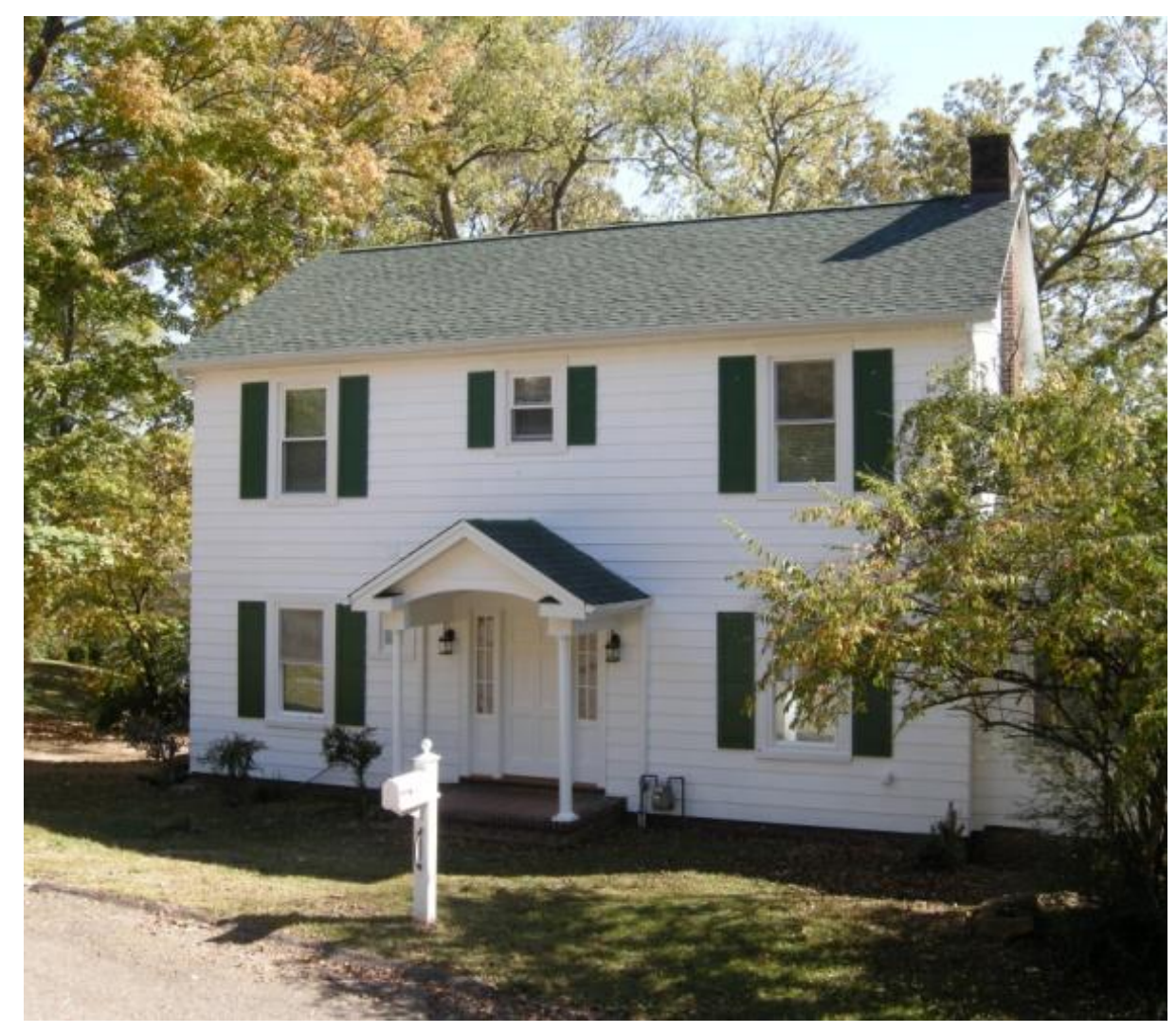

Built in the 1940s, Gaiter is a two-story, single-family detached home with $1,769 \mathrm{ft}^{2}$. Gaiter is home to one adult. The first floor has $974 \mathrm{ft}^{2}$, the second floor has $795 \mathrm{ft}^{2}$, and the basement has $974 \mathrm{ft}^{2}$. The basement is not included in the conditioned floor area of the home. There are three bedrooms and two bathrooms. Gaiter has a traditional vented attic and an unfinished unconditioned basement.

The Gaiter home has not been occupied for several years. During the renovation and energy retrofit the drywall was removed from the inside of the home. This creates a unique opportunity to insulate the walls and is typically called a "gut retrofit." Because the home was unoccupied prior to the retrofits, energy bills are not available for this home. The homeowner originally planned to renovate the home and update it to local code. After it was determined that this would require gutting the house, the homeowner decided to also install energy efficiency measures. There was some concern from the homeowner in keeping some historical features of the home intact, such as the ALCOA aluminum siding (one of the first homes in the area to receive such siding) and the bare brick walls in the basement for aesthetic purposes. 
GaITER Pre-RETrofit

\section{CharaCTERISTICS}

TYPE: Two-story, single-family

home

SIZE: $1,769 \mathrm{ft}^{2}$

Occupancy: One adult

\section{INITIAL ENVELOPE}

\section{PROFILE}

BASEMENT WALLS: NONE

BASEMENT FRAMED CEILING

INSULATION: NONE

ABOVE GRADE WALL

INSULATION: NONE

ATTIC INSULATION: R-7

CATHEDRAl CEILING: NonE

\section{INITIAL MECHANICAL \\ PROFILE}

HVAC: Unknown

WATER HEATER: Unknown

\section{INITIAL DIAGNOSTIC}

\section{RESULTS}

HERS: 259

AIR INFILTRATION (GUTTED

HOME):

$6,603 \mathrm{cfm}_{50}\left(16.9 \mathrm{ACH}_{50}\right)$

DUCT LEAKAGE TO OUTSIDE:

$619 \mathrm{cfm}_{25}$ (estimated)

DUCT INSULATION: R-4

(estimated)

\section{Gaiter Pre-Retrofit Condition}

\section{Envelope Profile}

The pre-retrofit building envelope is shown in Figure 17. The building envelope is bounded below by the unconditioned basement. There is no pressure or thermal barrier on the framed basement ceiling between the basement and level 1, and there is no insulation on the brick basement walls. The exterior walls of the first and second floor have no insulation. The attic floor has minimal insulation that is ineffective, having only an average R-value of R-7. There is a cathedral ceiling above the sunroom that has no insulation. There are also major infiltration issues in the attic floor and soffits, as can be seen in Figure 18.

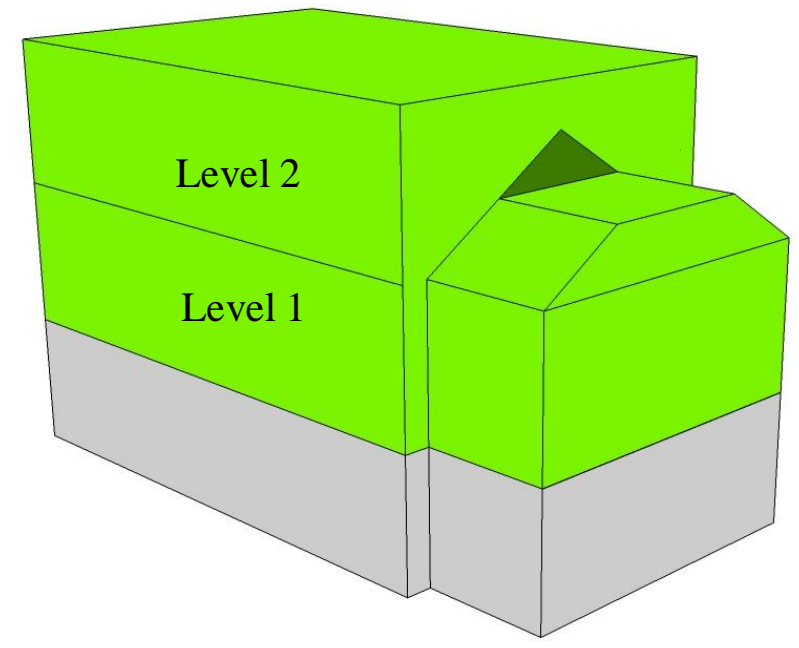

Figure 17: Gaiter initial envelope profile. Dark green indicates a knee wall. The grey walls represent the below-grade walls of the basement. Although this space is not conditioned, it is part of the thermal/pressure envelope.

The windows in the home are all single pane, with a mixture of vinyl and wood frames. The wood windows are over 50 years old.

During the initial home energy assessment, a blower door test was conducted to evaluate the air infiltration. The total air leakage rate was $6,603 \mathrm{cfm}_{50}$. It should be noted that at this point the home was completely gutted. The volume of the home is 23,474 , including the basement. The air exchange rate for the gutted home was approximately $16.9 \mathrm{ACH}_{50}$. 


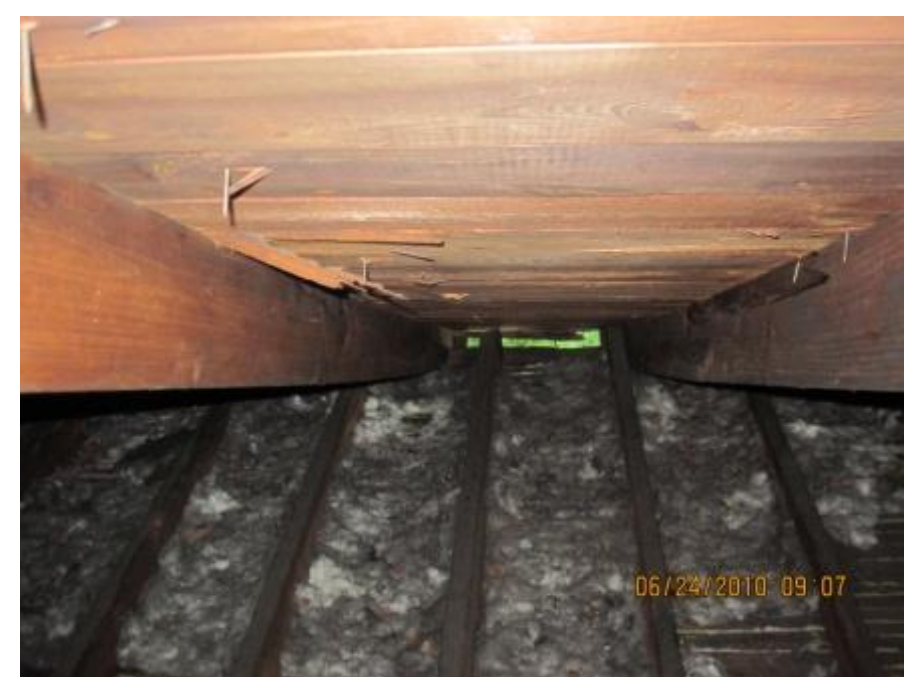

Figure 18: Attic insulation in Gaiter home.

\section{HVAC}

The pre-retrofit HVAC system specifications and ductwork condition in this home are unknown. For modeling the pre-retrofit home in EnergyGauge ${ }^{\circledR}$, a 3-ton 10 SEER AC and a 96-kBtuh 75\% AFUE gas furnace were used. Discussion on the appropriate estimation of the HVAC equipment capacity and efficiency is presented in the introduction. This model is used to calculate a preretrofit HERS index, as well as estimate pre-retrofit energy consumption and energy cost. An estimated duct leakage of $35 \%$ by conditioned floor area was used for duct leakage. This amounts to about $619 \mathrm{cfm}_{25}$ of duct leakage to the outside.

\section{Lighting, Water Heating, Appliances}

The pre-retrofit lighting, water heater, and appliance specifications are unknown for Gaiter. For modeling the pre-retrofit home in EnergyGauge ${ }^{\circledR}, 100 \%$ incandescent bulbs and a 40-gal 0.54 EF natural gas water heater were used. For appliances, all the default values in EnergyGauge ${ }^{\circledR}$ were used.

\section{Retrofit Measures}

The following retrofits listed in Table 15 were recommended to the homeowner by the ORNL team.

Table 15: Gaiter retrofit list

\begin{tabular}{|l|l|}
\hline \multicolumn{1}{|c|}{ Improvement } & \multicolumn{1}{c|}{ Existing condition } \\
\hline Air seal & $\sim 1 \mathrm{ACH}_{\text {natural }}$ \\
\hline Insulate brick walls in basement to R-10 & None \\
\hline Insulate walls to R-16 & None \\
\hline Insulate attic floor to R-50 & $\mathrm{R}-7$ \\
\hline $\begin{array}{l}\text { Install SEER 18 heat pump with ducts 100\% in } \\
\text { conditioned space }\end{array}$ & Unknown \\
\hline Replace windows with low-E triple pane (R-5) & $\begin{array}{l}\text { Wood frame single-pane windows } \\
\text { (50+ years old) }\end{array}$ \\
\hline Install ENERGY STAR® appliances & Unknown \\
\hline
\end{tabular}




\begin{tabular}{|l|l|}
\hline Install a heat pump water heater & Unknown \\
\hline Install 100\% CFL lighting & Unknown \\
\hline${ }^{a}$ ACHnatural = ACH50/Ncorrected, where Ncorrected is the height-corrected LBL "N-factor" \\
(http://www.bpi.org/Web\%20Download/BPI\%20Standards/Building\%20Analyst\%20Professional_2- \\
28-05nNC-newCO.pdf)
\end{tabular}

\section{Envelope}

The brick basement walls were not insulated because of bulk moisture issues that first need to be addressed. The south facing basement wall is the only basement wall that is framed and not brick. This wall was sealed with $1 / 2$ in. of closed-cell spray foam and insulated with un-faced fiberglass batts (R-13). No drywall was installed over these walls, so the cavities are open to the basement; this results in a total R-value of R-16 for the framed basement wall. The band joist that was accessible from the basement was sealed and insulated with 1 in. of closed-cell foam to R-6. The basement ceiling was not sealed or insulated. Since this home was a gut retrofit, the building cavities were easily accessible. Because of this, the walls were flashed with 1 in. of closed-cell foam over which fiberglass batts (R-13) were installed to bring the wall assemblies to $\mathrm{R}-16$. The roof deck was foamed with 1 in. of closed-cell spray foam over which $8 \mathrm{in}$. of opencell foam was applied. This brought the roof deck insulation to R-34. The ridge and soffits were stuffed with fiberglass batts and then foamed over with closed-cell foam. The cathedral ceiling above the sunroom was sprayed with 4 in. of closed-cell foam, resulting in an insulating value of R-24. Figure 19 shows the post-retrofit envelope profile of the home after the attic roof deck was sealed.

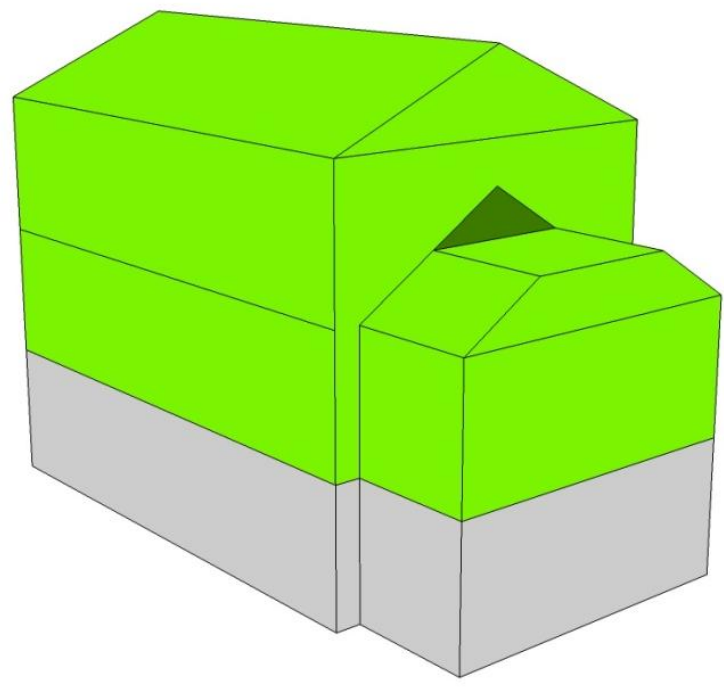

Figure 19: Post-retrofit envelope of the Gaiter home. Dark green indicates a knee wall.

The wood frame single-pane windows were replaced with triple-pane high-efficiency windows (U-factor of 0.2, SHGC of 0.35). 


\section{HVAC}

A high-efficiency 3-ton capacity unit was installed in the basement with an efficiency rating of 18 SEER and 9.5 HSPF. All new ducts were installed in the home and sealed with liquid mastic.

\section{Lighting, Water Heating, Appliances}

An electric heat pump water heater was installed with a 2.4 EF rating. An ENERGY STAR ${ }^{\circledR}$ refrigerator was installed. The lighting in Gaiter is 90\% CFL (70 bulbs total with 7 incandescent).

\section{Simulated Energy Savings}

EnergyGauge ${ }^{\circledR}$ software was used to estimate the energy and dollar savings from the installation of the retrofit package. Although the mechanical equipment capacity and efficiency were estimated for the pre-retrofit condition, the only way to quantitatively estimate energy savings is to compare the post-retrofit home to an estimated pre-retrofit condition. The model was built using the information presented above and assumed an "average" house. Table 16 shows the estimated energy and energy bill savings and the neutral cash flow for the retrofits. The amortized cost is the yearly payment on a 15 -year loan at $7 \%$ interest for the total retrofit cost. The net cost is the yearly loan payment minus the yearly estimated utility cost savings.

Table 16: EnergyGauge ${ }^{\circledR}$ estimated energy and cost savings for retrofits with neutral cash flow analysis

\begin{tabular}{|c|c|c|c|c|c|c|c|}
\hline & $\begin{array}{l}\text { Site } \\
\text { energy } \\
\text { (MMBtu) }\end{array}$ & $\begin{array}{l}\text { Utility } \\
\text { cost } \\
(\$ / y r)\end{array}$ & $\begin{array}{l}\text { Utility } \\
\text { cost } \\
\text { savings } \\
(\$ / y r)\end{array}$ & $\begin{array}{l}\text { Site } \\
\text { energy } \\
\text { savings } \\
\text { (MMBtu) }\end{array}$ & $\begin{array}{l}\text { Total } \\
\text { Retrofit } \\
\text { cost } \\
\text { (\$) }\end{array}$ & $\begin{array}{l}\text { Amortized } \\
\text { cost } \\
(\$ / y r)\end{array}$ & $\begin{array}{l}\text { Net cost } \\
(\$ / y r)\end{array}$ \\
\hline \begin{tabular}{|l}
$\begin{array}{l}\text { Pre- } \\
\text { retrofit } \\
\text { house }\end{array}$ \\
\end{tabular} & 279 & 4,024 & & & & & \\
\hline \begin{tabular}{|l}
$\begin{array}{l}\text { Post- } \\
\text { retrofit } \\
\text { house }\end{array}$ \\
\end{tabular} & 46.8 & 1,196 & 2,828 & 232.2 & 39,699 & 4,282 & 1,454 \\
\hline
\end{tabular}

\section{Diagnostics and Test-Out}

Blower door tests at intervals were attempted to investigate the effectiveness of different retrofit measures. The test results at these intervals are shown in Table 17 in the order the retrofits were implemented. Sealing the above-grade walls with 1 in. of closed-cell foam was the biggest single improvement to the air infiltration. The final air infiltration of the Gaiter house is $2,082 \mathrm{cfm}_{50}$; this is a $68 \%$ reduction in the original infiltration rate. It should be noted that the $\mathrm{ACH}_{50}$ results shown in the table include the basement volume, because the basement ceiling is not sealed and so the basement volume is within the pressure and thermal envelope. 
New ducts were installed in the Gaiter home in the unconditioned basement and the sealed attic. Table 18 shows that the post-retrofit duct leakage to the outside was measured to be $90 \mathrm{cfm}_{25}$. As a ratio of the conditioned area, this is a duct leakage of $4.6 \%$.

Overall, the final HERS index improved from 259 to 75 . After the retrofits were completed, the whole house energy consumption, along with the contribution of major loads such as the airconditioner, water heater, and appliances are being sub-metered by a Campbell Scientific data logger. Additionally, temperature, humidity, water flow, gas flow, and heat flux on the northwest basement walls are being measured.

Table 17: Pre-retrofit and post-retrofit air infiltration diagnostics

\begin{tabular}{|c|c|c|}
\hline Retrofit measure tested & $\begin{array}{c}\text { Blower door test result } \\
\left(\mathrm{cfm}_{50} / \mathrm{ACH}_{50}\right)\end{array}$ & $\begin{array}{c}\text { Percent } \\
\text { reduction }^{a}\end{array}$ \\
\hline Initial & $6,603 / 16.9$ & \\
\hline $\begin{array}{l}\text { Spray foam on ridge, soffit, roof deck, } \\
\text { sunroom ceiling, and gable ends }\end{array}$ & $6,003 / 15.3$ & 9 \\
\hline $\begin{array}{l}\text { Spray foam on all above-grade walls, } \\
\text { band joist between first and second floor, } \\
\text { around windows }\end{array}$ & $4,169 / 10.7$ & 28 \\
\hline $\begin{array}{l}\text { Spray foam on basement band joist, } \\
\text { framed basement wall }\end{array}$ & $3,752 / 9.6$ & 6 \\
\hline $\begin{array}{l}\text { Used IR camera to direct additional } \\
\text { application of spray foam to above-grade } \\
\text { walls where air infiltration was detected }\end{array}$ & $2,868 / 7.3$ & 13 \\
\hline $\begin{array}{l}\text { Used IR camera to direct additional } \\
\text { application of spray foam to walls and } \\
\text { attic where air infiltration was detected }\end{array}$ & $2,651 / 6.8$ & 3 \\
\hline $\begin{array}{l}\text { After drywall was installed, walls } \\
\text { painted and sealed windows }\end{array}$ & $2,185 / 5.6$ & 7 \\
\hline After all retrofits were completed & $2,082 / 5.3$ & 2 \\
\hline Final & $2,082 / 5.3$ & 68 \\
\hline
\end{tabular}

${ }^{a}$ Percent reduction is determined by evaluating the cfm50 reduction for each of the retrofit measures as a ratio of the total building infiltration

Table 18: Duct leakage test results

\begin{tabular}{|c|c|c|}
\hline & $\mathbf{c f m}_{\mathbf{2 5}}$ & Leakage to outside \\
\hline Initial & N/A & N/A \\
\hline Post & 90 & $5 \%^{a}$ \\
\hline \% Reduction & N/A & N/A \\
\hline
\end{tabular}

${ }^{a}$ Floor area is $1,769 \mathrm{ft}^{2}$. 


\section{Gaiter Cost and Scope of Work}

The retrofit measures described in this report were completed in December 2011, with a total cost of $\$ 39,699$. Table 19 provides a summary of the final scope of work and breakdown of the costs. Since this home is a gut-retrofit and has not been occupied for some time the incremental cost for mechanical equipment and appliances will be used. For estimated lighting costs, the difference between purchasing a 13-W CFL and a $60-\mathrm{W}$ incandescent was used for the $63 \mathrm{CFL}$ bulbs in the home. For estimating the refrigerator retrofit cost, the difference in cost between upgrading to an $18-\mathrm{ft}^{2} 15.9 \mathrm{EF}$ or $21.9 \mathrm{EF}$ refrigerator with a top mount freezer was used. The incremental costs were also used for the space conditioning and DHW equipment. The billed cost of the HVAC system was $\$ 12,500$, and according to the National Residential Efficiency Measures (NREM) Database the cost to install a 3-ton, 13 SEER 7.7 HSPF system is $\$ 4,680$. Therefore the incremental cost for the space conditioning equipment is $\$ 7,820$. The incremental cost between a 50 gallon natural gas water heater with a $0.58 \mathrm{EF}$ and a 50 gallon heat pump water heater with a $2.4 \mathrm{EF}$ was used for the DHW costs.

Table 19: Gaiter final scope of work and costs

An asterisk following the cost of a retrofit indicates that this cost is an estimate based on data found at the NREM database (http://www.nrel.gov/ap/retrofits/group_listing.cfm)

\begin{tabular}{|c|c|c|c|}
\hline Home characteristics & Existing conditions & Measures & Proposed costs \\
\hline Attic & $\begin{array}{l}\text { None - R-15 on attic } \\
\text { floor }\end{array}$ & $\begin{array}{l}\text { Insulated roof deck to } \\
\text { R-34 }\end{array}$ & $\$ 6,251$ \\
\hline $\begin{array}{c}\text { Cathedral ceiling in } \\
\text { sunroom }\end{array}$ & N/A & $\mathrm{R}-24$ & $\$ 828$ \\
\hline $\begin{array}{l}\text { Exterior walls (including } \\
\text { framed basement wall) }\end{array}$ & R-2 to R-5 & $\mathrm{R}-16$ & $\$ 2,665$ \\
\hline Band-joist in basement & None & $\mathrm{R}-6$ & $\$ 280$ \\
\hline Cooling & N/A & $\begin{array}{l}3 \text { ton, } 18 \text { SEER heat } \\
\text { pump }\end{array}$ & \multirow{2}{*}{$\$ 7,820$} \\
\hline Heating & N/A & 9.5 HSPF & \\
\hline DHW & N/A & $\begin{array}{l}2.4 \mathrm{EF} \text { electric heat } \\
\text { pump }\end{array}$ & $\$ 1,360 *$ \\
\hline Windows & $\begin{array}{l}\text { Single pane wood or } \\
\text { vinyl frame windows }\end{array}$ & $\begin{array}{l}\text { Triple pane U-0.2; } \\
\text { SHGC-0.35 }\end{array}$ & $\$ 20,000$ \\
\hline Appliances & No appliances & $\begin{array}{l}\text { ENERGY STAR® } \\
\text { refrigerator }\end{array}$ & $\$ 350^{*}$ \\
\hline Lighting & None & $90 \% \mathrm{CFL}$ & $\$ 145^{*}$ \\
\hline Total & & & $\$ 39,699$ \\
\hline
\end{tabular}




\section{Green Home Profile}

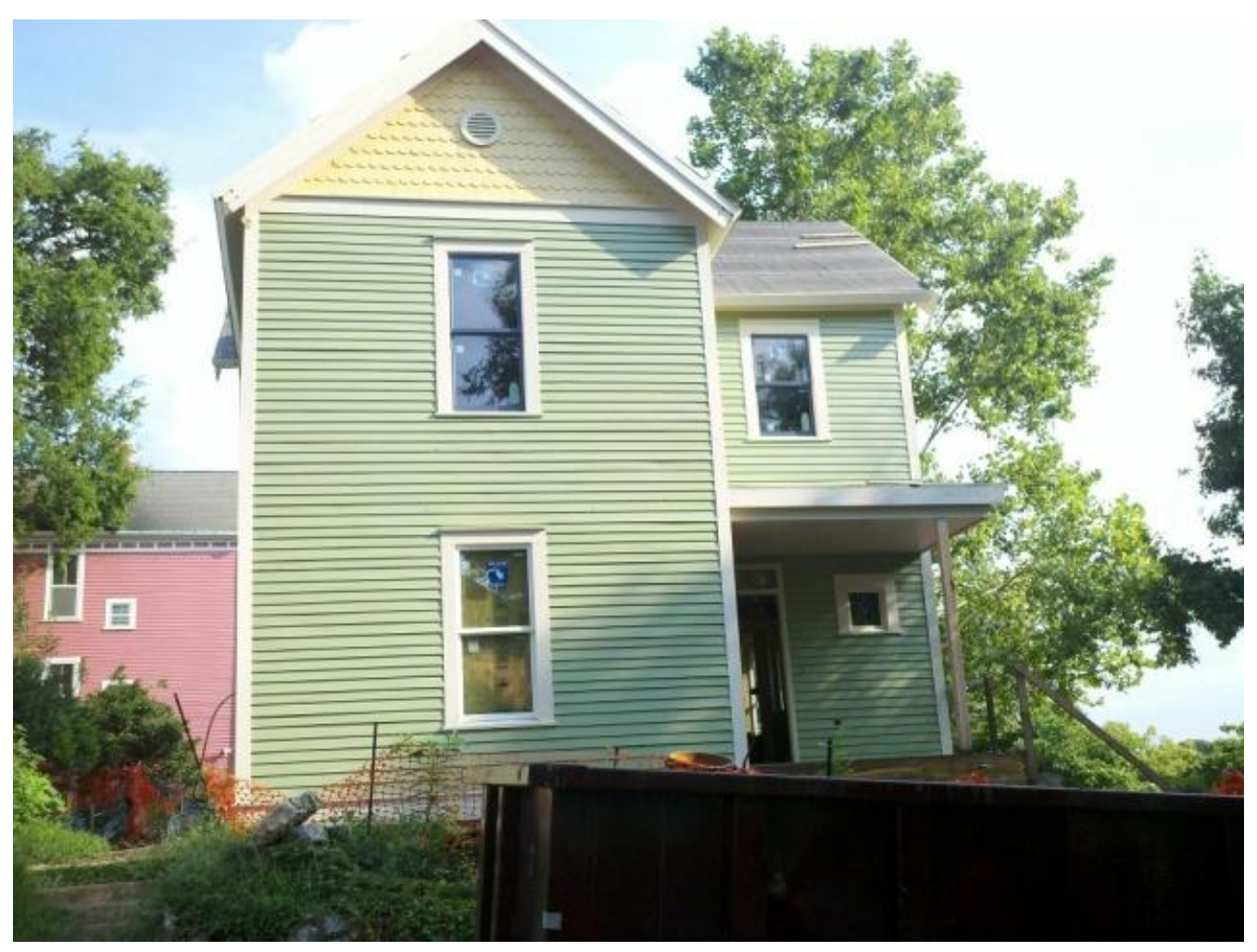

Built in 1909, Green is a two-story, single-family detached home with 2,295 $\mathrm{ft}^{2}$ of living area. In total, there are three bedrooms and two and a half bathrooms in this home. Green has a vented attic and a vented basement/crawlspace. This home was unoccupied for some time until being purchased by a historic preservation organization that decided to complete a gut retrofit of this home to update it for selling. Since this home is on the historic register, there were constraints on what retrofits could be done, but the owning organization still intended to strive for LEED certification of this home.

There are no utility bills available for the household. 


\section{GREen PRE-RETROFIT}

CHARACTERISTICS

TYPE: 2-story, single-family

home

SIZE: $2,295 \mathrm{ft}^{2}$

Occupancy: Two adults

\section{INITIAL ENVELOPE}

\section{PROFILE}

BASEMENT/CRAWL WALL

INSULATION: NONE

BASEMENT/CRAWL CEILING

INSULATION: NONE

WALL INSULATION: R-5

BAND JOIST INSULATION: NONE

ATTIC INSULATION: NONE

\section{INITIAL MECHANICAL}

\section{PROFILE}

HVAC: Unknown

WATER HEATER: Unknown

\section{INITIAL DIAGNOSTIC}

\section{RESULTS}

HERS: 186

AIR INFILTRATION:

$4,749 \mathrm{cfm}_{50}\left(13.1 \mathrm{ACH}_{50}\right)$

DUCT LEAKAGE TO OUTSIDE:

$803 \mathrm{cfm}_{25}$ (ESTIMATED)

DUCT INSULATION: R-4

(ESTIMATED)

\section{Green Pre-Retrofit Condition}

\section{Envelope Profile}

The building envelope is bounded below by a basement/crawlspace. There is no insulation on the basement and crawlspace walls or ceilings. The home has balloon framing, so the basement is intimately connected to the attic. This feature makes air sealing a significant task. The walls were assumed to have about R-5. The vented attic tops the building envelope, which has no insulation. Figure 20 below provides a 3-D visual of the home, illustrating the pre-retrofit envelope profile.

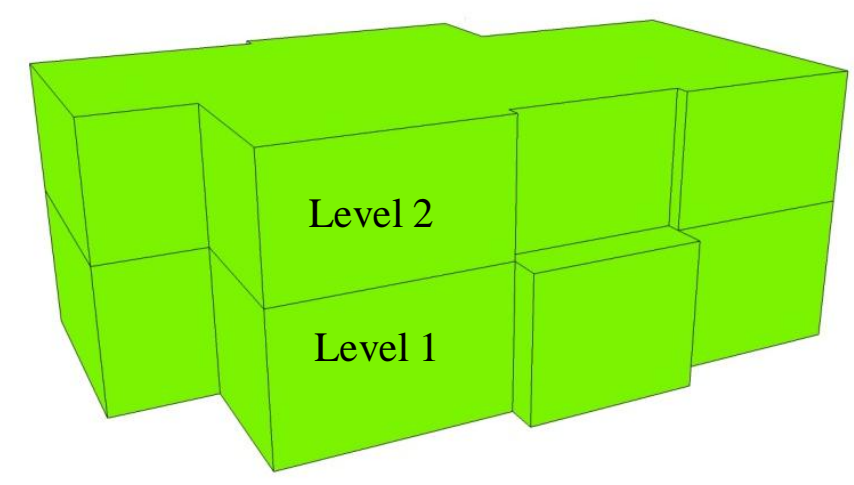

Figure 20: Pre-retrofit envelope of the Green home.

No blower door test was conducted for the pre-retrofit condition of the home; therefore, the air infiltration will be estimated as $0.75 \mathrm{ACH}_{\text {natural }}$. This amounts to $4,749 \mathrm{cfm}_{50}$ of air infiltration, or $13.1 \mathrm{ACH}_{50}$, based on the home volume of $21,819 \mathrm{ft}^{3}$.

\section{HVAC}

The pre-retrofit HVAC system specifications and ductwork condition in this home are unknown. For modeling the pre-retrofit home in EnergyGauge ${ }^{\circledR}$, a 4-ton 10 SEER AC and a 120-kBtuh 75\% AFUE gas furnace were used. Discussion on the appropriate estimation of the HVAC equipment capacity and efficiency is presented in the introduction. The model is used to calculate a pre--retrofit HERS index, as well as estimate pre-retrofit energy consumption and energy cost. An estimated duct leakage of $35 \%$ by conditioned floor area was used for duct leakage. This amounts to about $803 \mathrm{cfm}_{25}$ of duct leakage to the outside. 


\section{Lighting, Water Heating, Appliances}

The pre-retrofit lighting, water heater, and appliance specifications are unknown for Green. For modeling purposes, $100 \%$ incandescent bulbs and a 50-gallon $0.58 \mathrm{EF}$ natural gas water heater were used. For appliances, all the default values in energy gauge were used.

\section{Retrofit Measures}

The following retrofits were recommended by the ORNL team.

Table 20: Green retrofit list

\begin{tabular}{|l|l|}
\hline \multicolumn{1}{|c|}{ Improvement } & \multicolumn{1}{c|}{ Existing condition } \\
\hline Air sealing & N/A \\
\hline $\begin{array}{l}\text { Insulate attic roof to R-38, walls to R- } \\
\text { 16, and basement walls to R-10 }\end{array}$ & Attic: None, Walls: R-5 \\
Basement: None
\end{tabular}

\section{Envelope}

The basement walls were insulated and sealed using 2-in. foam panels (R-10) connected directly to the interior of the walls. On top of the foam, a vinyl vapor barrier was installed. A vapor barrier was also installed on the dirt crawlspace floor. House wrap was installed on the exterior walls and integrated into the sealed attic. R-16 insulation was installed in the wall cavities. The attic roof deck was sealed and insulated with R-38 closed-cell spray foam. Figure 21 shows the post-retrofit envelope profile of the Green home showing the sealed and insulated attic roof deck. Figure 22 shows the sealed attic and the insulated band joist between floors. The weather wrap was extended from the wall into the closed soffit space, where it was intended to be sealed to the roof deck with open cell foam. New windows were installed with a U-factor of 0.3 and SHGC of 0.2 .

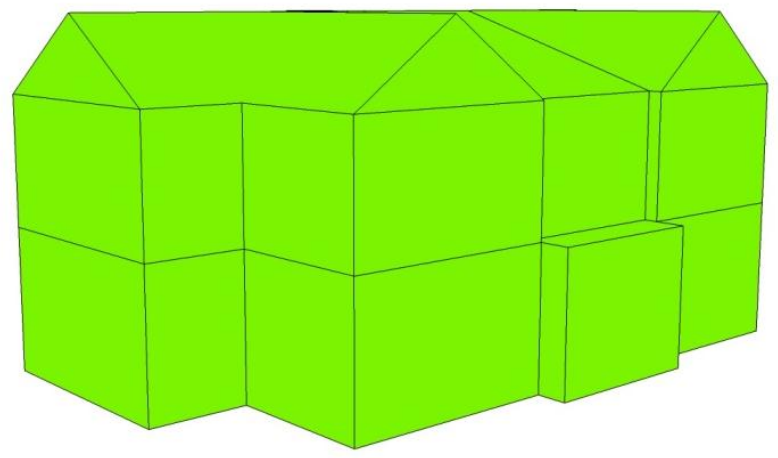

Figure 21: Post-retrofit envelope profile of the Green home. 

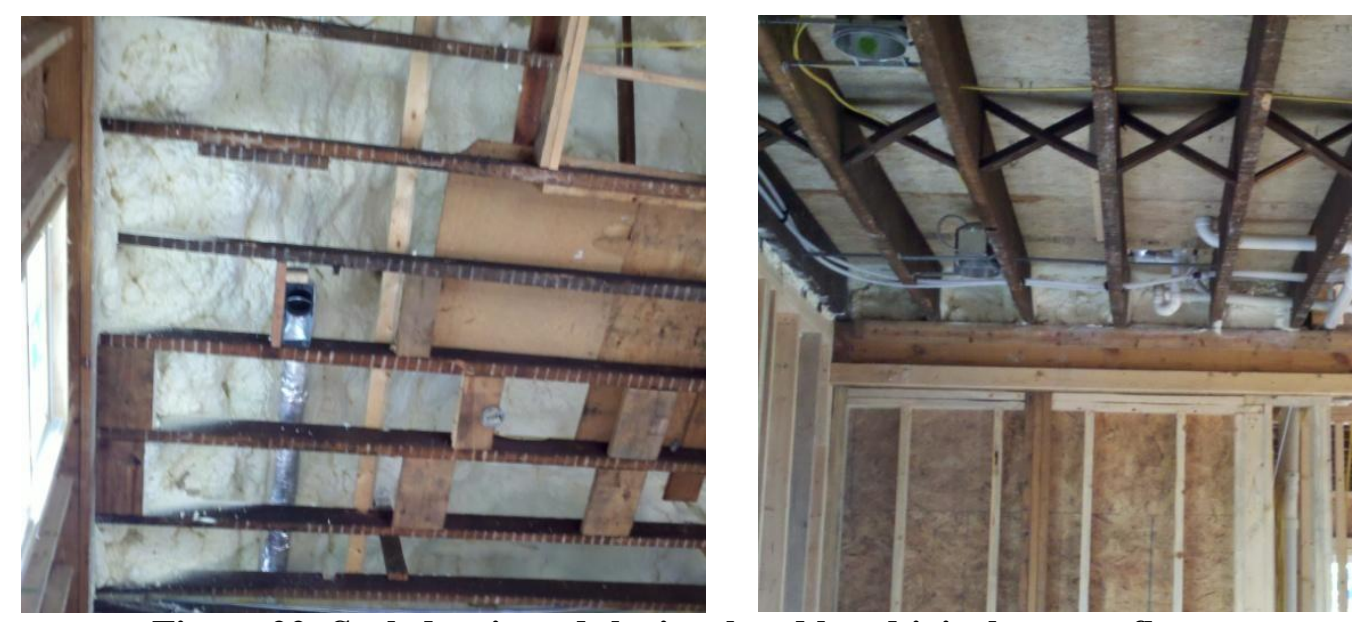

Figure 22: Sealed attic and the insulated band joist between floors.

\section{HVAC}

A new-variable capacity ducted heat pump was installed with a capacity of 3 tons and an efficiency of 20.5 SEER and 13 HSPF. The air-handler unit was installed in the basement, and the ducts are in the basement and sealed attic. The ductwork was insulated with R-6 duct wrap.

\section{Lighting, Water Heating, Appliances}

A solar water heater was installed with an electric backup. The solar water heater is an active indirect system meaning that pumps move the fluid from the $1200-\mathrm{ft}^{2}$ collector (Dawn Solar Systems - cross-linked polyethylene tubing imbedded in the purlins) underneath the standing seam metal roof to the heat exchanger wrapped around the outside of the inner water jacket of the DHW tank. The collector is split along three roof faces - one with an azimuth of $70^{\circ}$, one with an azimuth of $160^{\circ}$, and the other at $250^{\circ}$, all with a tilt of $39^{\circ}$. A $1.428-\mathrm{kW}_{\text {peak }}$ laminate photovoltaic (PV) system was integrated into the standing seam metal roof to create a sandwich of PV/roof/solar thermal. The PV system has an area of $253 \mathrm{ft}^{2}$ and is split along two roof faces - one with an azimuth of $160^{\circ}$ and the other at $250^{\circ}$, both with a tilt of $39^{\circ}$. CFL lighting $(78 \%)$ was installed.

\section{Simulated Energy Savings}

EnergyGauge ${ }^{\circledR}$ software was used to estimate the energy and dollar savings from the installation of the retrofit package. Although the mechanical equipment capacity and efficiency were estimated for the pre-retrofit condition, the only way to quantitatively estimate energy savings is to compare the post-retrofit home to an estimated pre-retrofit condition. The model was built using the information presented above and assumed an "average" house. Table 21 shows the estimated energy and energy bill savings and the neutral cash flow for the retrofits. The amortized cost is the yearly payment on a 15-year loan at $7 \%$ interest for the total retrofit cost. The net cost is the yearly loan payment minus the yearly estimated utility cost savings. The total cost includes a 30\% tax incentive for solar thermal and solar PV that was installed on the home. Without taking into account PV generation, Green would have a post-retrofit energy consumption of $50 \mathrm{MMBtu}$ and an estimated total cost of $\$ 32,600$. 
Table 21: EnergyGauge ${ }^{\circledR}$ estimated energy and cost savings for retrofits with neutral cash flow analysis

\begin{tabular}{|c|c|c|c|c|c|c|c|}
\hline & $\begin{array}{l}\text { Site } \\
\text { energy } \\
\text { (MMBtu) }\end{array}$ & $\begin{array}{l}\text { Utility } \\
\text { cost } \\
(\$ / y r)\end{array}$ & $\begin{array}{l}\text { Utility } \\
\text { cost } \\
\text { savings } \\
\text { (\$/yr) }\end{array}$ & $\begin{array}{l}\text { Site energy } \\
\text { savings } \\
\text { (MMBtu) }\end{array}$ & $\begin{array}{l}\text { Total } \\
\text { Retrofit } \\
\text { cost } \\
(\$)\end{array}$ & $\begin{array}{l}\text { Amortized } \\
\text { cost } \\
(\$ / y r)\end{array}$ & $\begin{array}{l}\text { Net cost } \\
(\$ / y r)\end{array}$ \\
\hline $\begin{array}{l}\text { Pre- } \\
\text { retrofit } \\
\text { house }\end{array}$ & 217 & 4,568 & & & & & \\
\hline $\begin{array}{l}\text { Post- } \\
\text { retrofit } \\
\text { house }\end{array}$ & 45.5 & 1,501 & 3,067 & 171.5 & 45,462 & 4,904 & 1,837 \\
\hline
\end{tabular}

\section{Diagnostics and Test-Out}

Table 22 shows the post-retrofit blower door test results. The test resulted in 1,991 $\mathrm{cfm}_{50}$ of air infiltration, about 5.5 $\mathrm{ACH}_{50}$. Since no initial blower door test was conducted in the Green home no comparison to pre-retrofit infiltration is available.

Table 22: Pre-retrofit and post-retrofit air infiltration diagnostics

\begin{tabular}{|l|c|c|}
\hline Retrofit measure tested & $\begin{array}{c}\text { Blower door test result } \\
\left(\mathbf{c f m}_{\mathbf{5 0}} / \mathbf{A C H}_{\mathbf{5}}\right)\end{array}$ & Percent reduction \\
\hline Pre-Retrofit & N/A & N/A \\
\hline Final & $1,991 / 5.5$ & \\
\hline
\end{tabular}

Overall the final HERS index improved from 186 to 61 (with solar PV) or 67 (without solar PV). Upon completion of the retrofits, the whole house energy consumption, along with the contribution of major loads such as the air-conditioner, water heater, and appliances, is being sub-metered by a Campbell Scientific data logger. Additionally, temperature, humidity, water flow, and heat flux on the east basement wall are measured.

New ducts were installed in the Green home in the unconditioned basement and the sealed attic. Table 23 shows the post-retrofit duct leakage. A baseline duct leakage measurement was not conducted because no ductwork was installed in the home when the retrofit began. After the retrofits, the duct leakage to the outside was measured to be $74 \mathrm{cfm}_{25}$. As a ratio of the conditioned area, this is a duct leakage of $3.2 \%$.

Table 23: Duct leakage test results

\begin{tabular}{|c|c|c|}
\hline & $\mathbf{c f m}_{\mathbf{2 5}}$ & Leakage to outside \\
\hline Initial & N/A & N/A \\
\hline Post & 74 & $3.2 \%^{a}$ \\
\hline \% Reduction & N/A & N/A \\
\hline
\end{tabular}

${ }^{a}$ Floor area is $2,295 \mathrm{ft}^{2}$ 


\section{Green Cost and Scope of Work}

The retrofit measures described in this report were completed in May 2011. The total cost of the retrofit was $\$ 45,462$. Since this home is a gut-retrofit and has not been occupied for some time the incremental cost for mechanical equipment and appliances will be used. This figure assumes a 30\% tax incentive on the solar thermal and PV that were installed. For estimated lighting costs, the difference between purchasing a 13-W CFL and a 60-W incandescent was used for the 50 CFL bulbs in the home. Table 24 provides a summary of the final scope of work and breakdown of the costs. The cost for the heating and cooling system is the incremental cost between a 3ton, 13 SEER, 7.7 HSPF heat pump and a 3-ton, 20.5 SEER, 10 HSPF system (note that the installed system is not available as a cost estimate in the NREM database). The incremental cost between a 50 gallon natural gas water heater with a $0.58 \mathrm{EF}$ and the installed solar water heater was used.

Table 24: Green final scope of work and costs

An asterisk following the cost of a retrofit indicates that this cost is an estimate based on data found at http://www.nrel.gov/ap/retrofits/group_listing.cfm

\begin{tabular}{|c|c|c|c|}
\hline Home characteristics & Existing conditions & Upgrades & Costs \\
\hline Exterior Walls & N/A & $\mathrm{R}-16$ & \multirow{3}{*}{$\$ 13,506$} \\
\hline Attic & N/A & $\begin{array}{l}\mathrm{R}-38 \text { on underside } \\
\text { of roof deck }\end{array}$ & \\
\hline Basement Walls & N/A & $\begin{array}{l}\text { R-10 foam panels } \\
\text { on basement walls } \\
\text { with vapor barrier }\end{array}$ & \\
\hline Cooling & N/A & $\begin{array}{l}\text { 3-ton 20.5 SEER } \\
\text { variable capacity }\end{array}$ & \multirow{2}{*}{$\$ 2,160 *$} \\
\hline Heating & N/A & $13 \mathrm{HSPF}$ & \\
\hline DHW & N/A & Solar Water Heater & \multirow{2}{*}{$\begin{array}{c}\$ 26,364(\$ 18,232 \\
\text { with } 30 \% \text { tax } \\
\text { incentive })\end{array}$} \\
\hline PV & None & $\begin{array}{l}1.428-\mathrm{kW} \\
\text { laminate } \mathrm{PV}\end{array}$ & \\
\hline Windows & Single-pane wood & $\begin{array}{c}\text { ENERGY STAR } ® \\
\text { windows: } U=0.3 \text {, } \\
\text { SHGC }=0.2\end{array}$ & $\$ 11,449^{*}$ \\
\hline Lighting & $100 \%$ incandescent & $78 \% \mathrm{CFL}$ & $\$ 115^{*}$ \\
\hline Total & & & $\begin{array}{l}\$ 45,462 \text { (with } 30 \% \\
\text { tax incentive) }\end{array}$ \\
\hline
\end{tabular}




\section{Eagle Home Profile}

Built in 1938, Eagle is a twostory, single-family detached home with 4,273 $\mathrm{ft}^{2}$ of living area. In total, there are three bedrooms and two and a half bathrooms in this home. Eagle has a small vented crawlspace, conditioned basement, and a vented attic. A family of two adults and one teenage child occupy this home. This home has gas heat, gas water heating, and electric AC.

The family's energy costs from January 2009 to December 2009 are shown in

Figure 23. With a total annual cost of \$3,504 (226 MMBtu of site energy), the family's energy costs are higher than the average annual site energy consumption for a typical home in the Southeast of this size (203 MMBtu*).

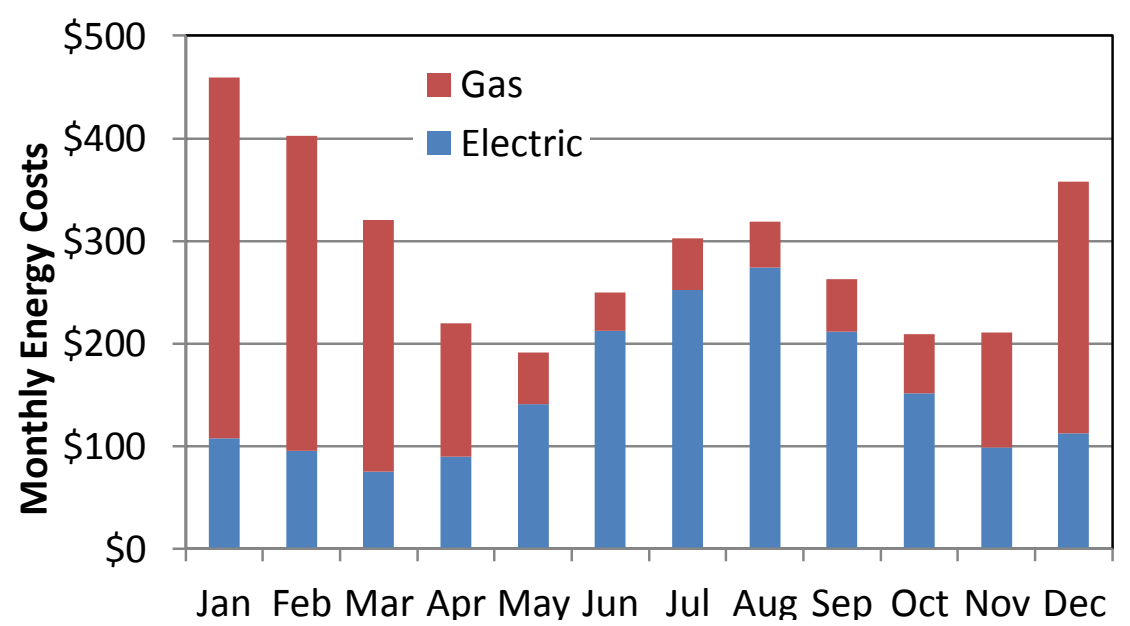

Figure 23: Eagle energy costs for 2009.

\footnotetext{
* Per the 2010 Buildings Energy Data Book, energy consumption for the South Atlantic region is 47.4 kBtu per square foot.
} 


\section{Eagle Pre-Retrofit Condition}

EAGLE Pre-RETROFIT

\section{CHARACTERISTICS}

TYPE: Two-story, single-family

home

SIZE: $4,273 \mathrm{ft}^{2}$

Occupancy: Two adults and

one teenage child

\section{INITIAL ENVELOPE}

PROFILE

BASEMENT CEILING

INSULATION: R-15

CRAWL SPACE CEILING

INSULATION: R-15

WALL INSULATION: R-11

ATTIC INSULATION: R-19

KNEE WALLS: NONE

ROOM OVER THE GARAGE

FLOOR: NONE

INITIAL MECHANICAL

Profile

Location: Conditioned

basement

Cooling: 5-ton 10 SEER AC

Heating: 96 kBtuh 80\% AFUE

Window unit A/C

WATER HEATER: 0.54 EF (gas)

\section{INITIAL DIAGNOSTIC}

RESULTS

HERS: 169

AIR INFILTRATION:

$7,621 \mathrm{cfm}_{50}\left(13 \mathrm{ACH}_{50}\right)$

DUCT LEAKAGE TO OUTSIDE:

$1495 \mathrm{cfm}_{25}$ (ESTIMATED)

DUCT INSULATION: R-2

\section{Envelope Profile}

The Eagle home has a conditioned basement used for storage and a vented crawlspace. The basement walls are cinderblock and are not insulated. The crawlspace and basement framed ceilings have $\mathrm{R}-15$ cavity insulation. The above-grade exterior walls are insulated to R-11, and the vented attic is insulated to R-19 on the attic floor. Figure 24 shows the envelope profile of Eagle. The windows in the home are double pane with vinyl frames or single pane with wood frames. The home has a whole house fan that is not used. There is a room over the garage with no insulation in the framed floor cavities. There are also uninsulated attic knee walls and a laundry chute that is open to the attic. Figure 25 shows both of these features.

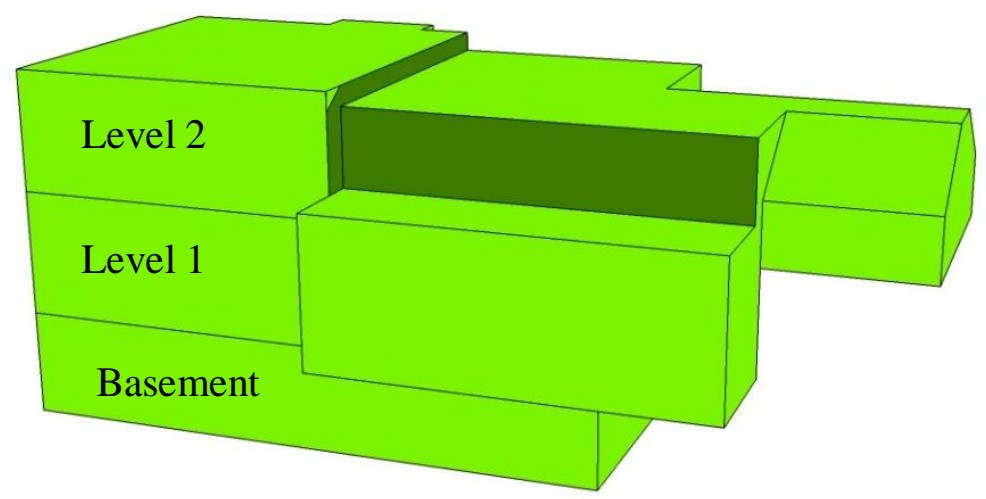

Figure 24: Envelope profile of Eagle. The dark green shade indicates knee walls.

During the initial home energy assessment, a blower door test was conducted to evaluate the air infiltration. The total air leakage rate was $7,621 \mathrm{cfm}_{50}$. With a conditioned volume of $35,250 \mathrm{ft}^{3}$, the air exchange rate for Eagle was approximately $13 \mathrm{ACH}_{50}$. 

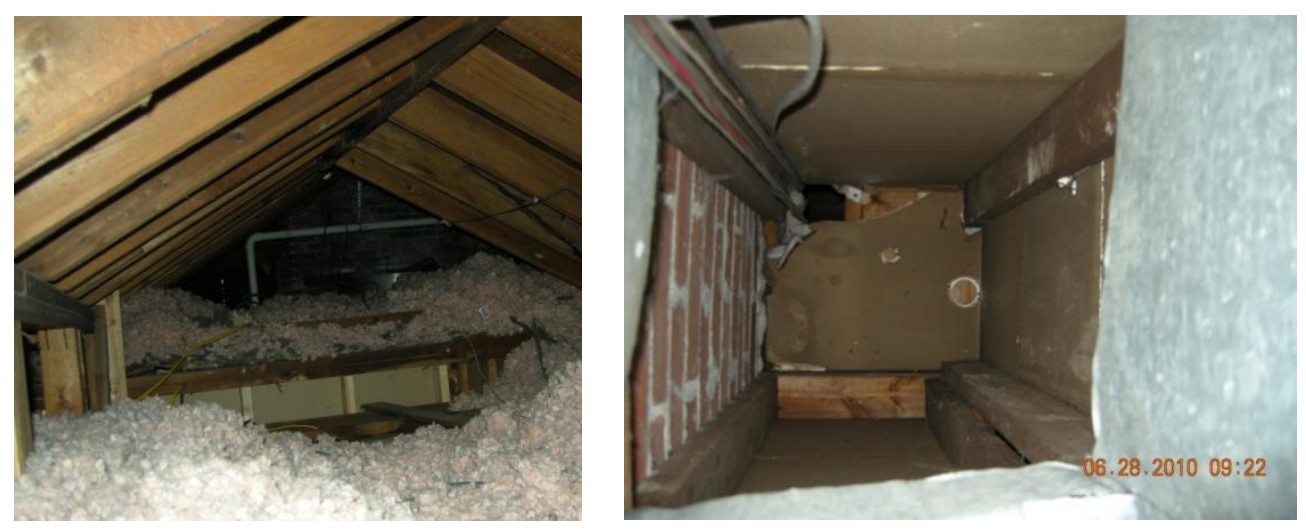

Figure 25: Uninsulated attic knee wall and laundry chute open to attic.

\section{HVAC}

The home has a 5-ton 10 SEER air conditioner and a 96-kBtuh 80\% AFUE gas furnace for heating. The unit is in the conditioned basement along with most of the ductwork. There is some ductwork in the exterior walls and a few ducts in the small crawl space servicing the breakfast area. The ductwork was too leaky to measure, so an estimated 1,495 $\mathrm{cfm}_{25}$ was used for modeling. This amounts to $35 \%$ duct leakage by conditioned floor area.

\section{Lighting, Water Heating, Appliances}

The Eagle home has a 0.54 EF 50-gallon natural gas water heater.

\section{Retrofit Measures}

The following retrofits were recommended by the ORNL researchers.

Table 25: Eagle retrofit recommendations

\begin{tabular}{|c|c|}
\hline Improvement & Existing condition \\
\hline Air sealing & $\sim 0.75 \mathrm{ACH}_{\text {natural }}{ }^{a}$ \\
\hline \multicolumn{2}{|l|}{ Remove whole house fan } \\
\hline Upgrade attic insulation to R-50 & R-19 \\
\hline $\begin{array}{l}\text { Replace HVAC with Geothermal heat pump (EER } \\
18.5 \text { and COP 3.8) with horizontal loop }\end{array}$ & 10 SEER / 80\% AFUE \\
\hline Upgrade windows & $\begin{array}{l}\text { Double and single pane windows; } \\
\text { Vinyl or wood frame }\end{array}$ \\
\hline Replace appliances with ENERGY STAR $®$ & No ENERGY STAR® appliances \\
\hline Replace incandescent bulbs with CFL & Incandescent \\
\hline Replace water heater with heat pump model $2.4 \mathrm{EF}$ & $0.54 \mathrm{EF}$ gas \\
\hline
\end{tabular}

\section{Envelope}

The homeowners have not completed any of the recommended retrofits. 


\section{HVAC}

The recommendation for a geothermal heat pump was made because the homeowners had an interest and there was a suitable site for the system. The homeowners have not completed any of the recommended retrofits.

\section{Lighting, Water Heating, Appliances}

The homeowners have not completed any of the recommended retrofits.

\section{Diagnostics and Test-Out}

Since no work was done at Eagle, there has been no test-out. However, speculations using EnergyGauge ${ }^{\circledR}$ on the post-retrofit condition of the home can be made as if the work recommended was completed. This was done to estimate the post-retrofit HERS as if the retrofits were completed. Overall, the HERS index estimation would have improved from 169 to 53.

\section{Eagle Cost and Scope of Work}

It would cost an estimated $\$ 36,417$ to complete all the recommended retrofits. Table 26 provides a summary of the final scope of work with associated costs. In the case of Eagle, all the costs for the retrofits were taken from the NREL National Residential Efficiency Measures Database."

\footnotetext{
* NREL National Residential Efficiency Measures Database http://www.nrel.gov/ap/retrofits/group_listing.cfm.
} 
Table 26: Eagle final scope of work and costs

\begin{tabular}{|c|c|c|c|}
\hline Home characteristics & $\begin{array}{l}\text { Pre-retrofit } \\
\text { conditions }\end{array}$ & Retrofit measures & Final costs \\
\hline Attic & $\mathrm{R}-19$ on attic floor & Insulate roof deck to R-50 & $\$ 2,000$ \\
\hline Cooling & 5-ton 10 SEER & $\begin{array}{l}1 \text { split geothermal cooling } \\
\text { EER } 18.5\end{array}$ & \multirow{2}{*}{$\$ 15,000$} \\
\hline Heating & $80 \%$ AFUE & $\begin{array}{c}1 \text { split geothermal heating } \\
\text { COP } 3.8\end{array}$ & \\
\hline Water Heating & $0.54 \mathrm{EF}$ & $\begin{array}{l}\text { 2.4 EF electric heat pump } \\
\text { water heater }\end{array}$ & $\$ 1500$ \\
\hline Air Infiltration & $18.13 \mathrm{ACH}_{50}$ & $5 \mathrm{ACH}_{50}$ & $\$ 2,569$ \\
\hline Windows & $\begin{array}{l}\text { Double-pane vinyl } \\
\text { frame }\end{array}$ & $\begin{array}{c}\text { Triple-pane } \mathrm{U}=0.2 ; \\
\mathrm{SHGC}=0.35\end{array}$ & $\$ 14,000$ \\
\hline Lighting & $100 \%$ Incandescent & $100 \% \mathrm{CFL}$ & $\$ 368$ \\
\hline Appliances & $\begin{array}{l}\text { No EnergyStar® } \\
\text { appliances }\end{array}$ & EnergyStar ${ }^{\circledR}$ refrigerator & $\$ 980$ \\
\hline Total & & & $\$ 36,417$ \\
\hline
\end{tabular}




\section{Scenic Home Profile}

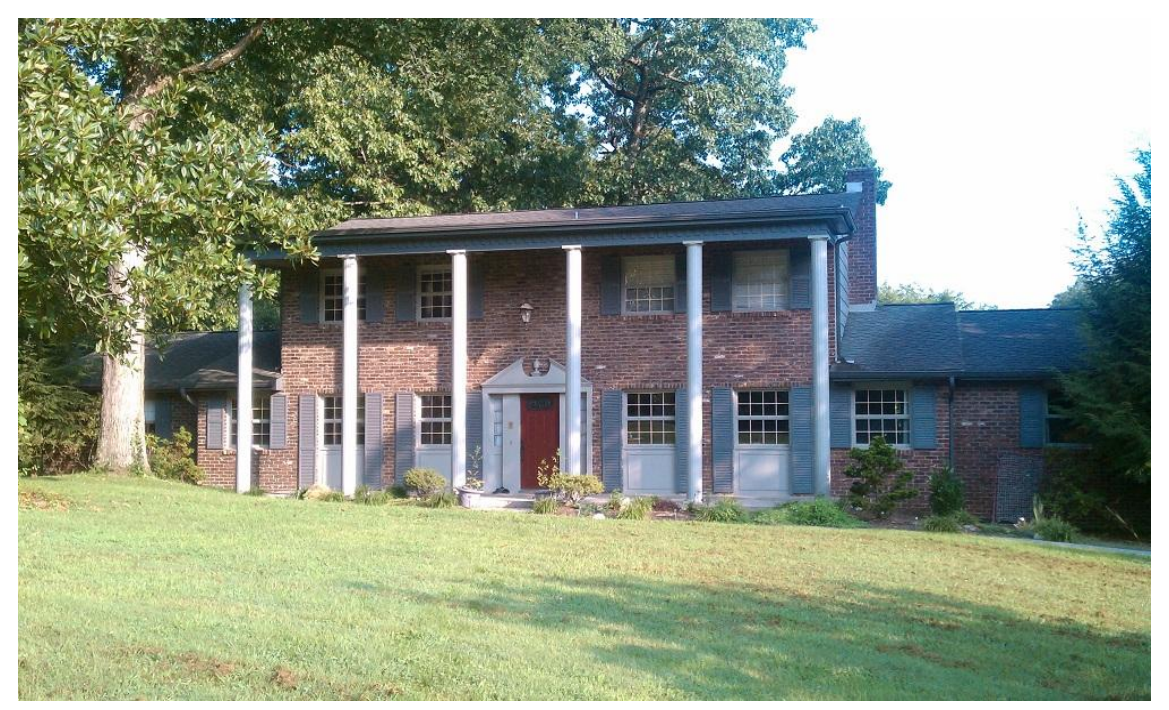

Built in 1966, Scenic is a two-story, single-family detached home with 4,328 $\mathrm{ft}^{2}$ of living area. In total, there are three bedrooms and two bathrooms in this home. Scenic has a vented crawlspace, basement, and a vented attic. A family of four occupies this home. This home has gas heat and electric AC.

The family's energy costs from September 2008 to August 2009 are shown in Figure 26. With a total annual cost of $\$ 3,580$ (163 MMBtu of site energy), the family's energy costs are lower than the average annual site energy consumption for a typical home in the Southeast of this size (205 $\left.\mathrm{MMBtu}^{*}\right)$.

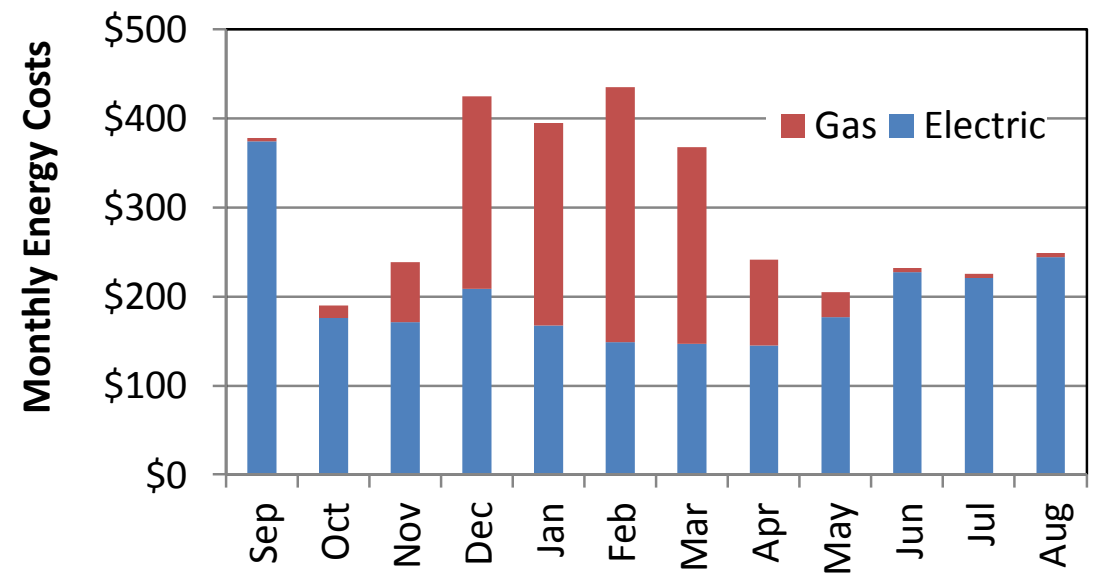

Figure 26: Scenic monthly energy costs.

\footnotetext{
${ }^{*}$ Per the 2010 Buildings Energy Data Book, energy consumption for the South Atlantic region is 47.4 kBtu per square foot.
} 


\section{Scenic Pre-Retrofit Condition}

SCENIC PRE-RETROFIT

\section{CharaCTERISTICS}

TYPE: Two-story, single-family home

SIZE: $4,328 \mathrm{ft}^{2}$

Occupancy: Two adults and two children

\section{INITIAL ENVELOPE}

\section{PROFILE}

BASEMENT CEILING

INSULATION: R-15

CRAWL SPACE CEILING

INSULATION: R-15

WALL INSULATION: R-13

ATTIC INSULATION: R-15 -

R-21

KNEE WALL INSULATION: R-13

ROOM ABOVE GARAGE FLOOR:

$\mathrm{R}-15$

\section{INITIAL MECHANICAL}

\section{ProfILE}

LEVEL 1:

Location: outside

Cooling: 3.5-ton 10 SEER AC

Heating: $100-\mathrm{kBtuh} 80 \%$

AFUE gas furnace

LEVEL 2:

Location: outside

Cooling: 2.5-ton 10 SEER AC

Heating: $100-\mathrm{kBtuh} 80 \%$

AFUE gas furnace

WATER HEATER: $0.91 \mathrm{EF}$

(electric)

\section{INITIAL DIAGNOSTIC}

\section{RESULTS}

HERS: 135

AIR INFILTRATION:

7,895 $\mathrm{cfm}_{50}\left(13.7 \mathrm{ACH}_{50}\right)$

DUCT LEAKAGE TO OUTSIDE:

Level 1: $1088 \mathrm{cfm}_{25}$ (ESTIMATED)

Level 2: $427 \mathrm{cfm}_{25}$ (ESTIMATED)

DUCT INSULATION: R-4

\section{Envelope Profile}

Figure 27 shows the envelope profile of the Scenic home. Scenic's lower boundary is made up of the insulated basement/crawlspace framed ceiling with R-15 cavity insulation. The above-grade walls are insulted to R-13. The home is capped with a vented attic with 5-7 in. of rock wool with insulation values from R-15 to R-21 on the attic floor. The general state of the insulation in the home is poor. Figure 28 shows the insulation in the attic and crawlspace that sparsely covers the thermal boundary. The knee wall is insulated to R-13. Scenic also has a room over the garage. The garage ceiling is insulated to R-15.

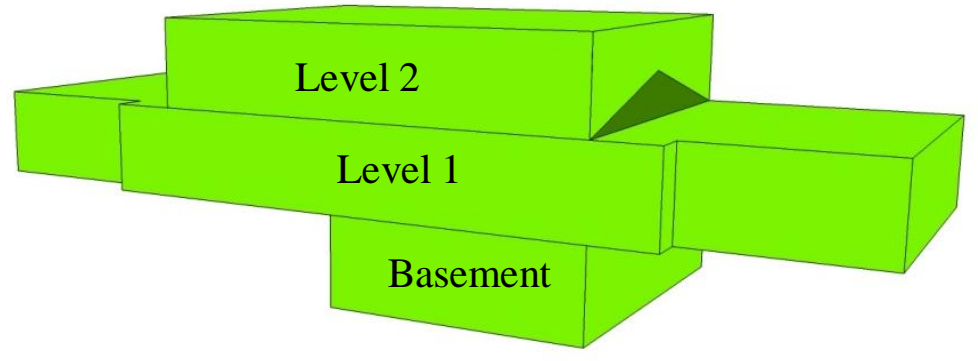

Figure 27: Scenic envelope profile. The dark green represents knee walls.
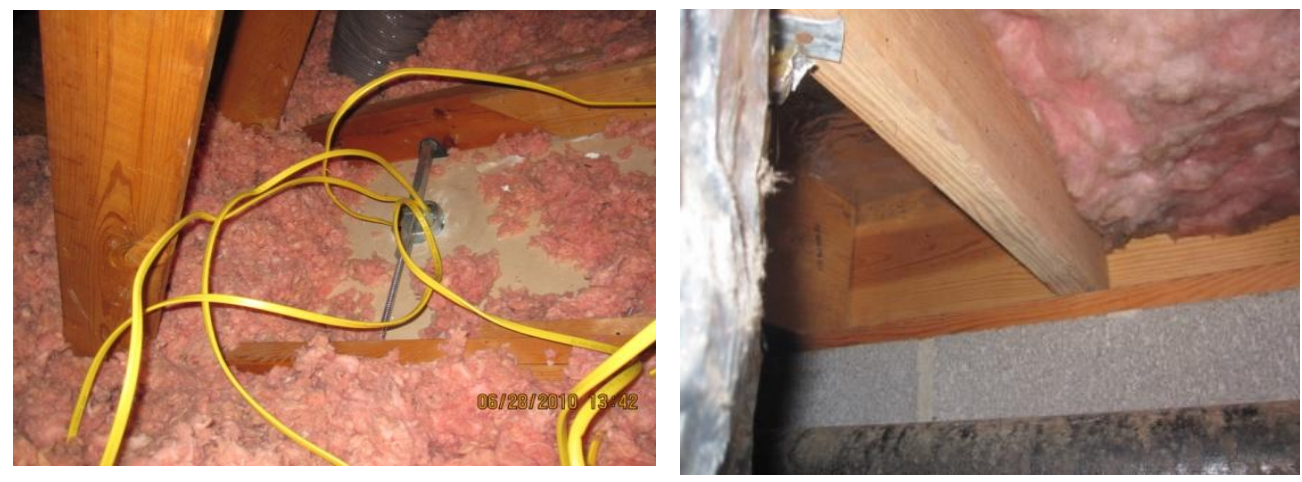

Figure 28: Insulation in the attic and crawlspace ceiling in the Scenic home is sparse.

The windows in the Scenic home are all single-pane windows with metal frames.

During the initial home energy assessment, a blower door test was conducted to evaluate the air infiltration. The total air leakage rate was $7,895 \mathrm{cfm}_{50}$. With a conditioned volume of $34,642 \mathrm{ft}^{3}$, the air exchange 
rate for Scenic was approximately $13.7 \mathrm{ACH}_{50}$.

\section{HVAC}

Scenic has two units, one servicing the downstairs and one servicing the upstairs. Both are package units located outside and share a common return plenum. The downstairs unit is a 3.5-ton, 10 SEER air-conditioner coupled with a 100-kBtuh, 80\% AFUE gas furnace. The upstairs unit is a 2.5-ton, 10 SEER air-conditioner coupled with another 100-kBtuh, 80\% AFUE gas furnace. The ducts are located in the vented attic and vented crawlspace, and the duct leakage was too large to measure. For modeling purposes, the duct leakage was estimated to be $35 \%$ of the serviced floor area, so for the level 1 unit, the duct leakage to the outside is $1088 \mathrm{cfm}_{25}$ and for the level 2 unit, the duct leakage to the outside is $427 \mathrm{cfm}_{25}$.

\section{Lighting, Water Heating, Appliances}

Scenic has a 0.91 EF 50-gallon electric resistance water heater.

\section{Retrofit Measures}

The following retrofits were recommended by ORNL.

Table 27: Scenic priority list

\begin{tabular}{|l|c|}
\hline \multicolumn{1}{|c|}{ Improvement } & Existing condition \\
\hline Air sealing & $\sim 0.79 \mathrm{ACH}_{\text {natural }}{ }^{a}$ \\
\hline Increase wall insulation & $\mathrm{R}-13$ \\
\hline $\begin{array}{l}\text { Upgrade space conditioning equipment to horizontal } \\
\text { loop geothermal system }\end{array}$ & $10 \mathrm{Seer} / 80 \%$ AFUE \\
\hline Upgrade windows & Single pane metal frame \\
\hline Upgrade attic insulation to R-50 & $\sim \mathrm{R}-18$ \\
\hline Replace water heater with heat pump unit 2.4 EF & $0.91 \mathrm{EF}$ electric \\
\hline Replace can lights with airtight models & Leaky can lights \\
\hline Replace lighting with CFL & Incandescent \\
\hline
\end{tabular}

${ }^{a} \mathrm{ACHnatural}=\mathrm{ACH} 50 / \mathrm{Ncorrected}$, where Ncorrected is the height-corrected LBL "N-factor" (http://www.bpi.org/Web\%20Download/BPI\%20Standards/Building\%20Analyst\%20Professional_228-05nNC-newCO.pdf)

\section{Envelope}

The homeowners sealed utility penetrations including where the chimney exits the envelope. The attic insulation was upgraded to R-38.

\section{HVAC}

The recommendation for a geothermal heat pump was made because the homeowners had an interest and there was a suitable site for the system. Instead, the homeowners installed a 3-ton 16 SEER 9 HSPF heat pump zoned system with a 95\% AFUE gas backup. The capacity of the backup heat is unknown.

\section{Lighting, Water Heating, Appliances}

The homeowners replaced incandescent bulbs with CFLs. 


\section{Simulated Energy Savings}

EnergyGauge ${ }^{\circledR}$ software was used to estimate the energy and dollar savings from the installation of the retrofit package. Table 28 shows the estimated energy and energy bill savings and the neutral cash flow for the retrofits. The amortized cost is the yearly payment on a 15 -year loan at $7 \%$ interest for the total retrofit cost. The net cost is the yearly loan payment minus the yearly estimated utility cost savings.

Table 28: EnergyGauge ${ }^{\circledR}$ estimated energy and cost savings for retrofits with neutral cash flow analysis

\begin{tabular}{|c|c|c|c|c|c|c|c|}
\hline & $\begin{array}{l}\text { Site } \\
\text { energy } \\
\text { (MMBtu) }\end{array}$ & $\begin{array}{l}\text { Utility } \\
\text { cost } \\
(\$ / y r)\end{array}$ & $\begin{array}{l}\text { Utility } \\
\text { cost } \\
\text { savings } \\
(\$ / y r)\end{array}$ & $\begin{array}{l}\text { Site } \\
\text { energy } \\
\text { savings } \\
\text { (MMBtu) }\end{array}$ & $\begin{array}{l}\text { Total } \\
\text { Retrofit } \\
\text { cost } \\
\text { (\$) }\end{array}$ & $\begin{array}{l}\text { Amortized } \\
\text { cost } \\
(\$ / y r)\end{array}$ & $\begin{array}{l}\text { Net cost } \\
(\$ / y r)\end{array}$ \\
\hline $\begin{array}{l}\text { Pre- } \\
\text { retrofit } \\
\text { house }\end{array}$ & 171 & 4,336 & & & & & \\
\hline $\begin{array}{l}\text { Post- } \\
\text { retrofit } \\
\text { house }\end{array}$ & 125 & 4,150 & 186 & 46 & 12,132 & 1,309 & 1,123 \\
\hline
\end{tabular}

\section{Diagnostics and Test-Out}

Since little work was done on Scenic, there has been no test-out. However, speculations using EnergyGauge ${ }^{\circledR}$ on the post-retrofit efficiency of the home can be made based on the work that was done. Overall the final HERS index improved from 135 to 119.

\section{Scenic Cost and Scope of Work}

The total retrofit cost for Scenic was $\$ 12,132$. Table 29 provides a summary of the final scope of work with associated costs. 
Table 29: Scenic final scope of work and costs

An asterisk following the cost of a retrofit indicates that this cost is an estimate based on data found at http://www.nrel.gov/ap/retrofits/group_listing.cfm

\begin{tabular}{|c|c|c|c|}
\hline Home Characteristics & $\begin{array}{l}\text { Pre-retrofit } \\
\text { conditions }\end{array}$ & Retrofit measures & Final costs \\
\hline Attic & $\begin{array}{l}\text { R-18 fiberglass (flat } \\
\text { ceiling) }\end{array}$ & $\begin{array}{l}\text { Attic floor insulated with } \\
\text { fiberglass to R-38 }\end{array}$ & $\$ 1,720$ \\
\hline Cooling & 10 SEER & $\begin{array}{l}3 \text { ton, } 16 \text { SEER, zoned } \\
\text { system }\end{array}$ & \multirow[b]{2}{*}{$\$ 10,080$} \\
\hline Heating & $\begin{array}{l}\text { 100-kBtuh } 80 \% \text { AFUE } \\
\text { space heaters where } \\
\text { needed }\end{array}$ & $\begin{array}{l}9 \text { HSPF with } 95 \% \text { AFUE gas } \\
\text { backup }\end{array}$ & \\
\hline Lighting & $100 \%$ incandescent & $100 \% \mathrm{CFL}$ & $\$ 332 *$ \\
\hline Total & & & $\$ 12,132$ \\
\hline
\end{tabular}




\section{Old Tavern Home Profile}

Built in 1977, Old Tavern is a two-story, single-family, detached home with $3,766 \mathrm{ft}^{2}$ of living area. In total, there are five bedrooms and two and a half bathrooms in this home. Old Tavern has a vented crawlspace, and a vented attic. A family of two adults and two teenagers occupy this home. This home has gas heat and electric air conditioning.

The family's energy costs from January 2009 - December 2009

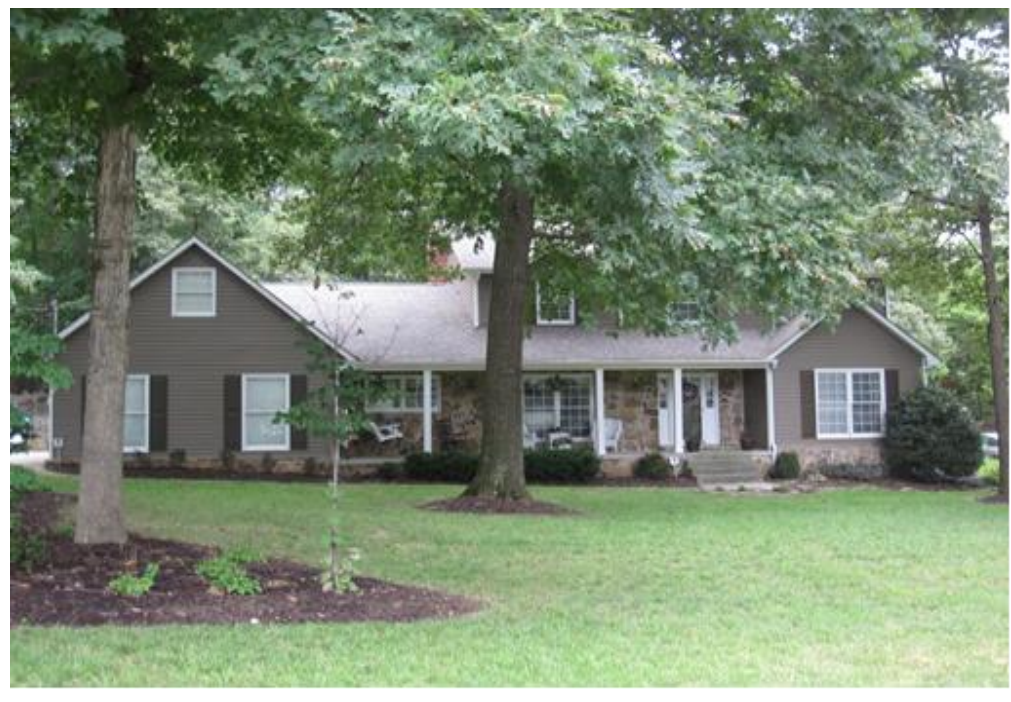
are shown in Figure 29. With a total annual cost of $\$ 4,317$ (232 MMBtu of site energy), the family's energy costs are higher than the average annual site energy consumption for a typical home in the southeast of this size (179 MMBtu*).

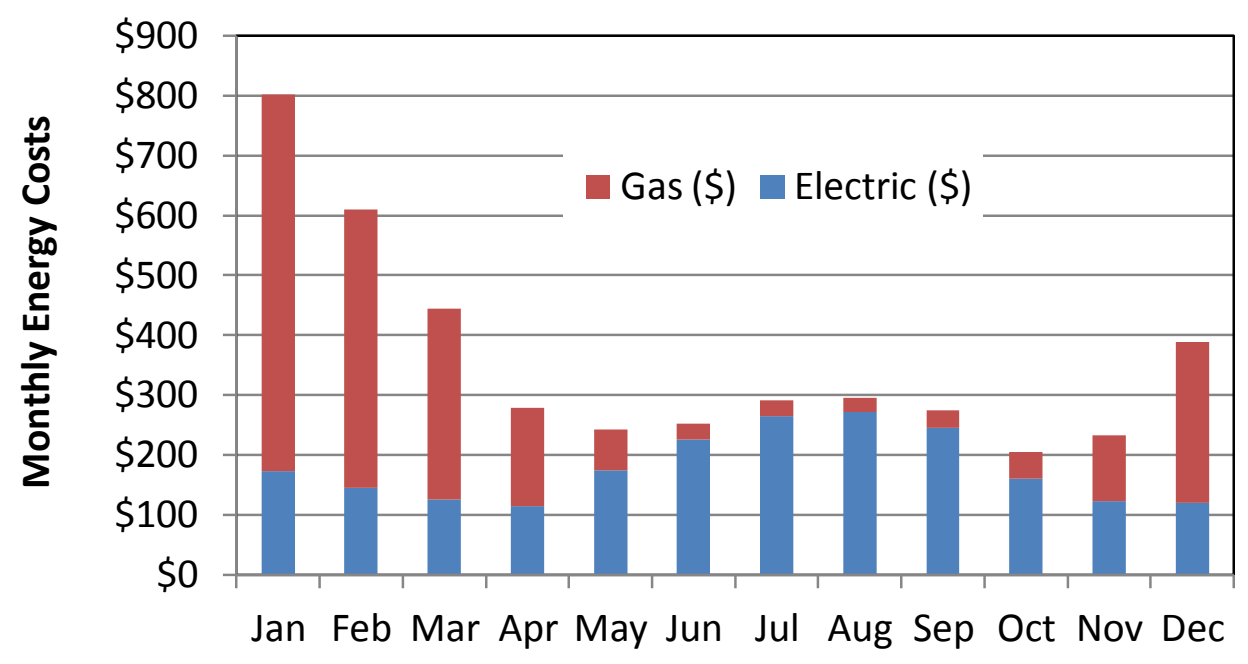

Figure 29: Old Tavern monthly energy costs.

\footnotetext{
${ }^{*}$ Per the 2010 Buildings Energy Data Book, energy consumption for the South Atlantic region is 47.4 kBtu per square foot.
} 


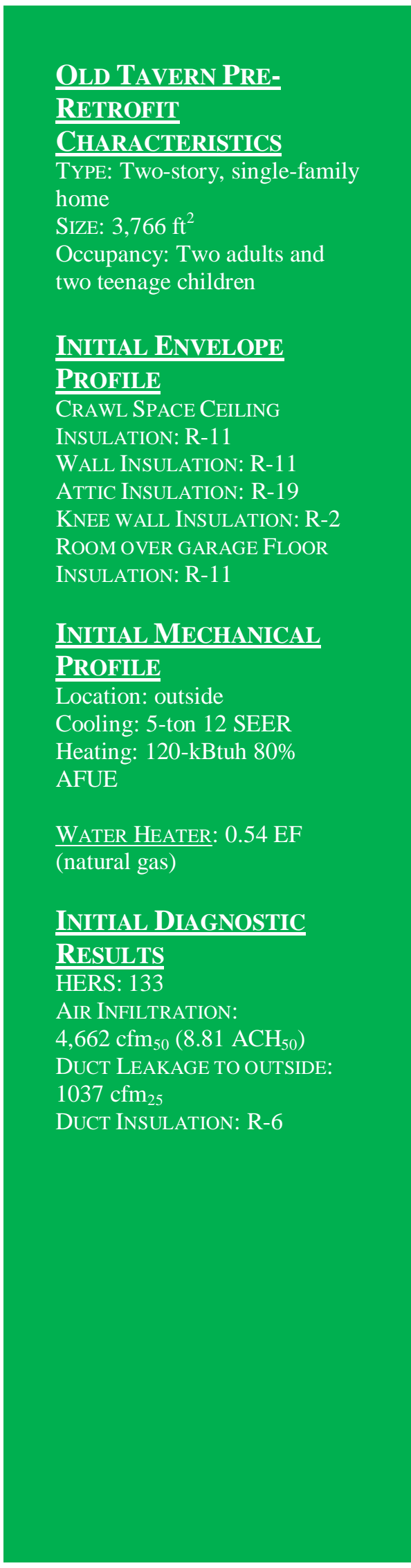

\section{Old Tavern Pre-Retrofit Condition}

\section{Envelope Profile}

The pre-retrofit envelope boundary of Old Tavern consists of a vented crawlspace with R-11 insulation on the crawlspace framed ceiling, above-grade walls with R-11 insulation, and a traditional vented attic insulated on the floor to R-19. A sketch of the pre-retrofit envelope profile of Old Tavern is shown in Figure 30. A room over the garage has insulation in the framed floor cavities of R-11. The home has slightly insulated attic knee walls (R-2) and an open chase that connects the living space to the attic, as shown in Figure 31.

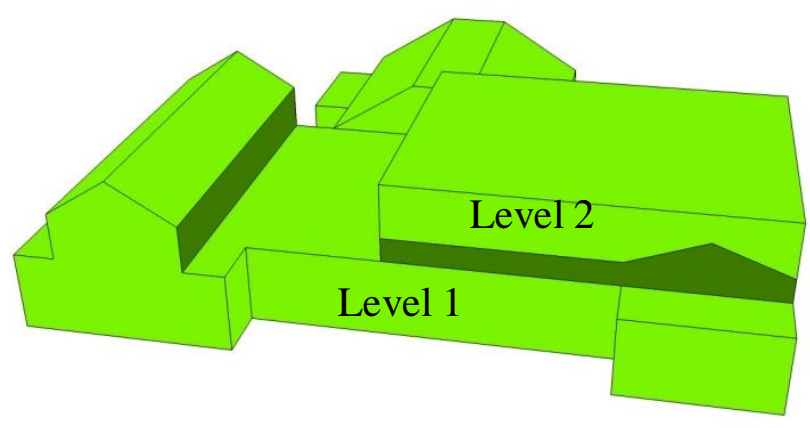

Figure 30: Old Tavern pre-retrofit envelope profile. Dark green represents knee walls.

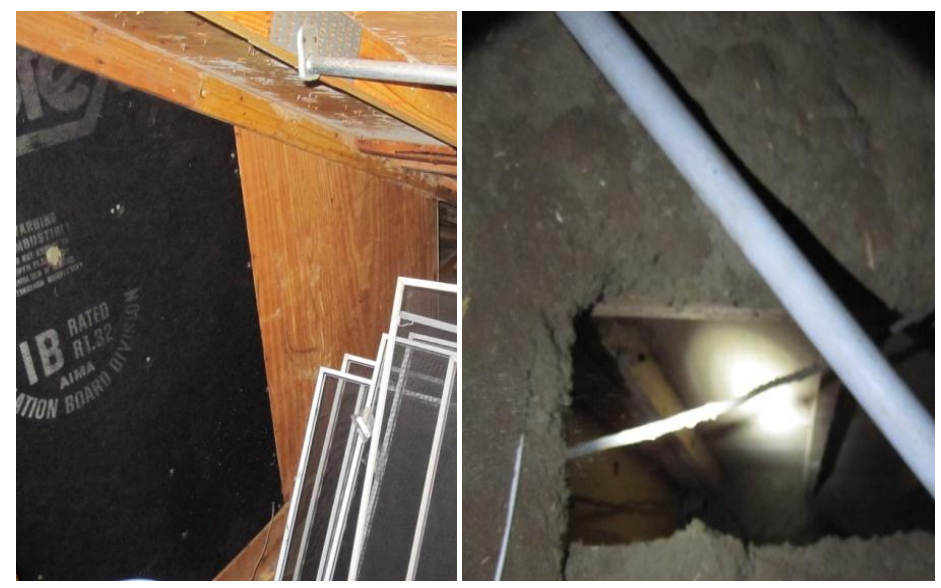

Figure 31: Uninsulated attic knee wall and unsealed attic chase. 
The windows of the home are double pane with wood frames.

During the initial home energy assessment, a blower door test was conducted to evaluate the air infiltration. The total air leakage rate was $4,662 \mathrm{cfm}_{50}$. With a conditioned volume of $31,756 \mathrm{ft}^{3}$, the air exchange rate for Old Tavern was approximately $8.81 \mathrm{ACH}_{50}$.

\section{HVAC}

Old Tavern has one package unit that is located outside. The unit is a 5-ton, 12 SEER air conditioner with a 120-kBtuh, $80 \%$ AFUE gas furnace. The ducts are in the sealed crawlspace and vented attic. The duct leakage to the outside was measured to be $1037 \mathrm{cfm}_{25}$. As a percentage of floor area, this is a leakage of $28 \%$.

\section{Lighting, Water Heating, Appliances}

Old Tavern has a 0.54 EF 50-gallon natural gas water heater.

\section{Retrofit Measures}

The following retrofits were recommended by ORNL.

Table 30: Old Tavern priority list

\begin{tabular}{|l|c|}
\hline \multicolumn{1}{|c|}{ Improvement } & Existing condition \\
\hline Air sealing & $\sim 0.51 \mathrm{ACH}_{\text {natural }}{ }^{a}$ \\
\hline Insulate crawlspace walls to R-10 & None \\
\hline $\begin{array}{l}\text { Insulate walls by removing exterior siding and } \\
\text { adding } 1 / 2 \text {-in. polystyrene insulation }\end{array}$ & $\mathrm{R}-11$ \\
\hline Seal and insulate attic to R-50 & R-19 \\
\hline Upgrade windows to Low E triple pane & Double-pane wood frame \\
\hline $\begin{array}{l}\text { Upgrade HVAC to heat pump SEER 16 with HSPF } \\
>9\end{array}$ & 5-ton 12 SEER \\
\hline $\begin{array}{l}\text { Replace water heater with heat pump model (2.4 } \\
\text { EF) }\end{array}$ & 0.54 EF gas \\
\hline Replace lights with all CFL & Incandescent \\
\hline
\end{tabular}

${ }^{a} \mathrm{ACHnatural}=\mathrm{ACH} 50 / \mathrm{Ncorrected}$, where Ncorrected is the height-corrected LBL "N-factor" (http://www.bpi.org/Web\%20Download/BPI\%20Standards/Building\%20Analyst\%20Professional_228-05nNC-newCO.pdf)

\section{Envelope}

The homeowners sealed the crawl space.

\section{HVAC}

The homeowners have not completed any of the recommended retrofits.

\section{Lighting, Water Heating, Appliances}

The homeowners have not completed any of the recommended retrofits. 


\section{Simulated Energy Savings}

EnergyGauge ${ }^{\circledR}$ software was used to estimate the energy and dollar savings from the installation of the retrofit package. Table 31 shows the estimated energy and energy bill savings and the neutral cash flow for the retrofits. The amortized cost is the yearly payment on a 15-year loan at $7 \%$ interest for the total retrofit cost. The net cost is the yearly loan payment minus the yearly estimated utility cost savings. In the case of Old Tavern, the cost for sealing the crawlspace was estimated using the NREL National Residential Efficiency Measures Database.*

Table 31: EnergyGauge ${ }^{\circledR}$ estimated energy and cost savings for retrofits with neutral cash

\begin{tabular}{|c|l|l|l|l|l|l|l|}
\hline & $\begin{array}{l}\text { Site } \\
\text { energy } \\
(\mathbf{M M B t u})\end{array}$ & $\begin{array}{l}\text { Utility } \\
\text { cost } \\
\mathbf{( \$ / y r )}\end{array}$ & $\begin{array}{l}\text { Utility } \\
\text { cost } \\
\text { savings } \\
\mathbf{( \$ / y r )}\end{array}$ & $\begin{array}{l}\text { Site } \\
\text { energy } \\
\text { savings } \\
\mathbf{( M M B t u})\end{array}$ & $\begin{array}{l}\text { Total } \\
\text { Retrofit } \\
\text { cost } \\
\mathbf{( \$ )}\end{array}$ & $\begin{array}{l}\text { Amortized } \\
\text { cost } \\
\mathbf{\$} / \mathbf{y r})\end{array}$ & $\begin{array}{l}\text { Net } \\
\text { cost } \\
\mathbf{( \$ / y r )}\end{array}$ \\
\hline $\begin{array}{c}\text { Pre- } \\
\text { retrofit } \\
\text { house }\end{array}$ & 239.1 & 4,515 & & & & & \\
\hline $\begin{array}{c}\text { Post- } \\
\text { retrofit } \\
\text { house }\end{array}$ & 231.5 & 4,410 & 105 & 7.6 & 1,838 & 198 & 93 \\
\hline
\end{tabular}

\section{Diagnostics and Test-Out}

Since little work was done on Old Tavern, there has been no test-out. However, speculations using EnergyGauge ${ }^{\circledR}$ can be made if the work recommended were completed. Overall, the final HERS index improved from 133 to 130.

\section{Old Tavern Cost and Scope of Work}

The total improvement cost for Old Tavern is estimated to be $\$ 1,838$. Table 32 provides a summary of the final scope of work with associated costs.

Table 32: Old Tavern final scope of work and costs

An asterisk following the cost of a retrofit indicates that this cost is an estimate based on data found at http://www.nrel.gov/ap/retrofits/group_listing.cfm

\begin{tabular}{|c|c|c|c|}
\hline Home characteristics & $\begin{array}{c}\text { Pre-retrofit } \\
\text { conditions }\end{array}$ & Retrofit measures & Final costs \\
\hline Foundation & None & Sealed crawlspace & $\$ 1,838^{*}$ \\
\hline Total & & & $\$ 1,838$ \\
\hline
\end{tabular}

* NREL National Residential Efficiency Measures Database http://www.nrel.gov/ap/retrofits/group_listing.cfm. 


\section{Capital Home Profile}

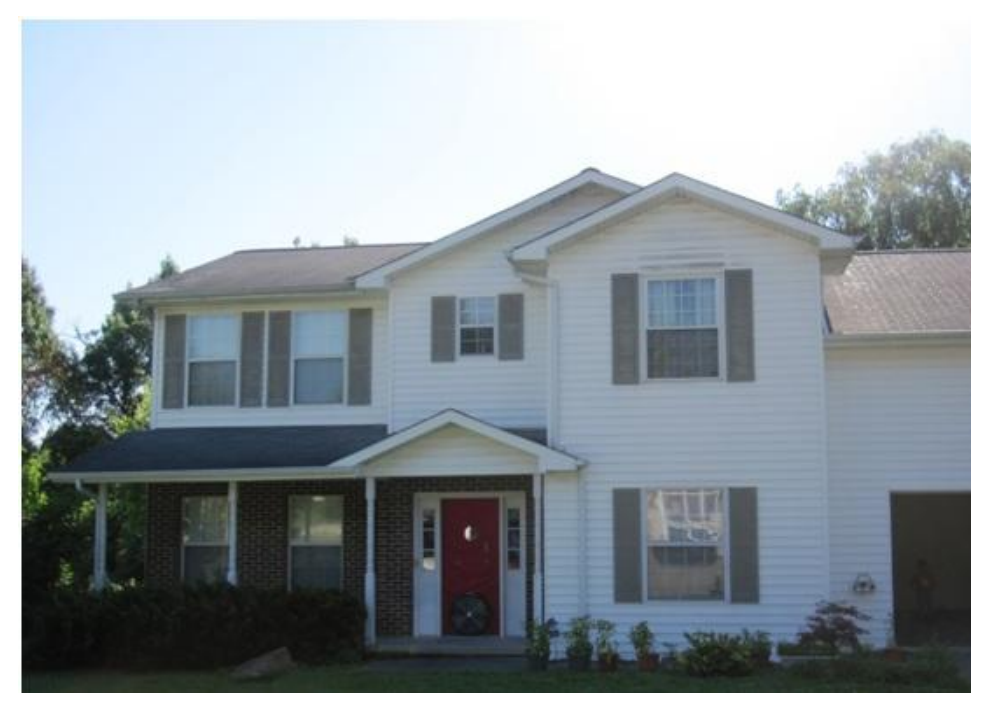

Built in 1993, Capital is a two-story, single-family detached home with 2,438 $\mathrm{ft}^{2}$ of living area. In total, there are four bedrooms and two and a half bathrooms in this home. Capital has a vented crawlspace and a vented attic. A family of two adults and two children occupy this home.

The family's energy costs from January 2009 to December 2009 are shown in Figure 32. With a total annual cost of $\$ 1,751$ (90 MMBtu of site energy), the family's energy costs are lower than the average annual site energy consumption for a typical home in the Southeast of this size

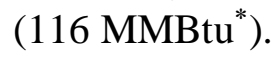

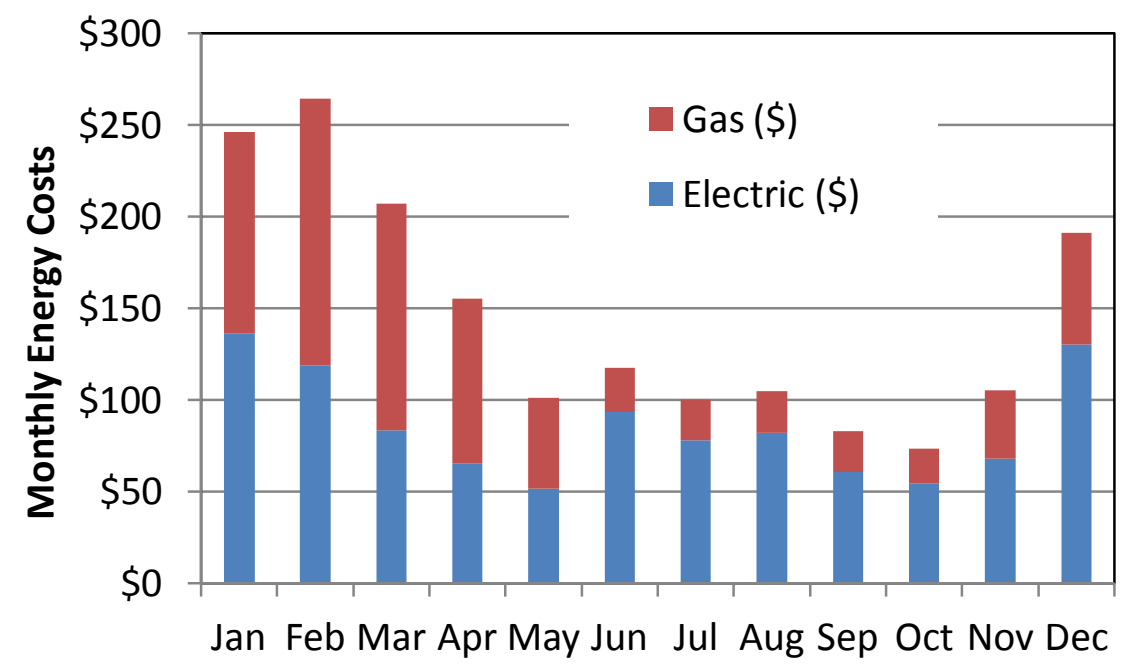

Figure 32: Capital monthly energy costs.

\footnotetext{
*Per the 2010 Buildings Energy Data Book, energy consumption for the South Atlantic region is 47.4 kBtu per square foot.
} 
CaPital Pre-Retrofit

CHARACTERISTICS

TYPE: Two-story, single-family home

SIZE: $2,438 \mathrm{ft}^{2}$

Occupancy: Two adults and two children

\section{INITIAL ENVELOPE}

\section{PROFILE}

CRAWL SPACE CEILING

INSULATION: R-19

WALL INSULATION: R-13

ATTIC INSULATION: R-25

ROOM OVER THE GARAGE

FLOOR INSULATION: R-15

KNEE WALL INSULATION: R-13

\section{INITIAL MECHANICAL}

\section{PrOFILE}

\section{LEVEL 1:}

Location: outside

Cooling: 2-ton 8 SEER AC

Heating: 64-kBtuh 80\% AFUE

\section{LEVEL 2:}

Location: conditioned space

Cooling: 2-ton 10 SEER heat

pump

Heating: 6.8 HSPF with 5-kW

back-up heat

WATER HEATER: 0.54 EF (gas)

\section{INITIAL DIAGNOSTIC}

\section{RESULTS}

HERS: 115

AIR INFILTRATION:

$2,694 \mathrm{cfm}_{50}\left(8.29 \mathrm{ACH}_{50}\right)$

DUCT LEAKAGE TO OUTSIDE:

Level 1: $124 \mathrm{cfm}_{25}$

Level 2: $136 \mathrm{cfm}_{25}$

DUCT INSULATION: R-4

\section{Capital Pre-Retrofit Condition}

\section{Envelope Profile}

The envelope profile of Capital is bounded below by a vented crawlspace with framed ceiling cavity insulation that has a value of R19 , above-grade exterior walls with R-13 insulation, and a vented attic with blown fiberglass insulation to R-25.

Capital has a room over the garage with a framed floor cavity that has an insulation value of R-15 and a knee wall with an insulation value of $\mathrm{R}-13$. Figure 33 shows the envelope profile of this home. The crawlspace of Capital showed signs of moisture issues, including possible mold on the joists and mud on top of the vapor barrier. Figure 34 shows these issues.

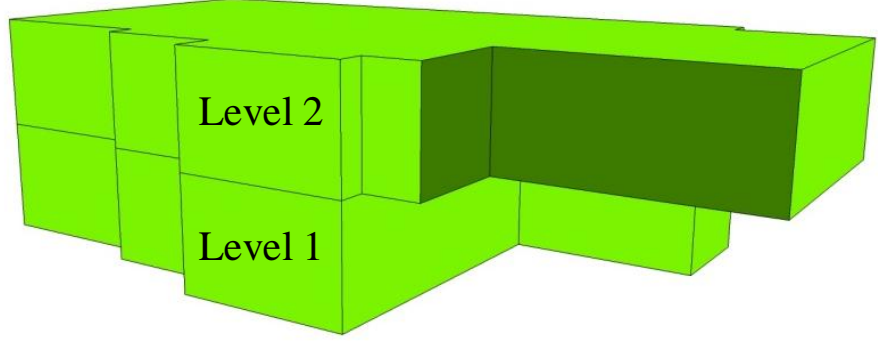

Figure 33: Capital pre-retrofit envelope profile. The dark green represents knee walls.
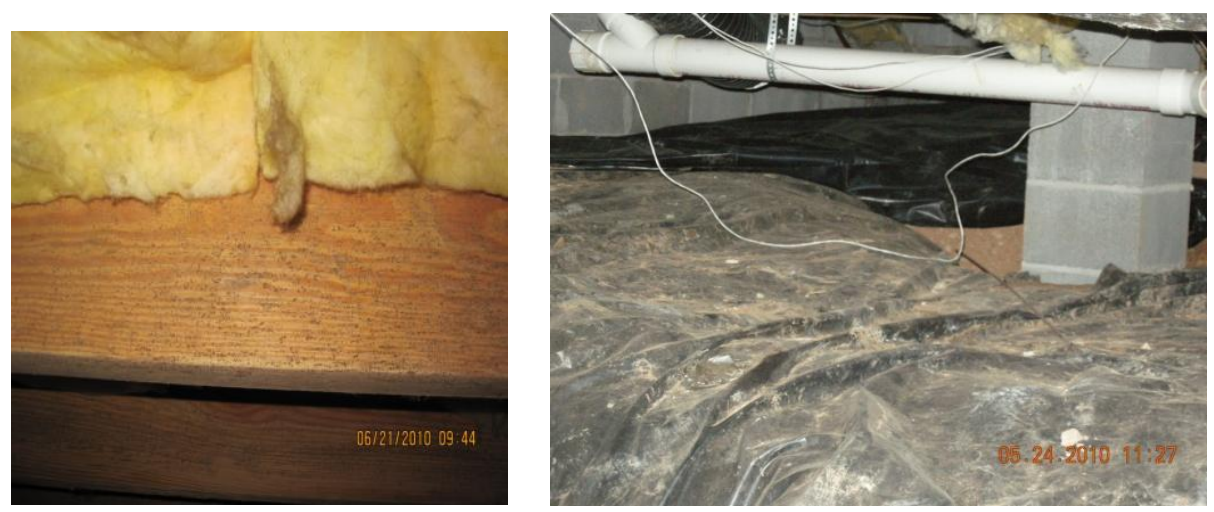

Figure 34: Moisture issues are apparent in the crawlspace of Capital.

The windows in the home are double pane with vinyl frames.

During the initial home energy assessment, a blower door test was conducted to evaluate the air infiltration. The total air leakage rate was 
$2,694 \mathrm{cfm}_{50}$. With a conditioned volume of $19,504 \mathrm{ft}^{3}$, the air exchange rate for Capital was approximately $8.29 \mathrm{ACH}_{50}$.

\section{HVAC}

Capital has two units, one for downstairs and one for upstairs. The downstairs AC is a package unit located outside with a capacity of 2-tons and efficiency of 8 SEER with a 64 -kBtuh $80 \%$ AFUE gas pack. The upstairs unit is a 2-ton 10 SEER heat pump with $6.8 \mathrm{HSPF}$. The unit is located in the conditioned space with ducts in the crawlspace. The duct work for the downstairs unit was measured to have a leakage rate to the outside of $124 \mathrm{cfm}_{25}$, and the upstairs duct work of $136 \mathrm{cfm}_{25}$. The ductwork for the downstairs is in the vented crawlspace, and the ductwork for the upstairs is between the two floors, so there is no ductwork in the attic. The downstairs unit services $1,083 \mathrm{ft}^{2}$, so the normalized duct leakage percentage by floor area is $11 \%$. The upstairs unit services $1,355 \mathrm{ft}^{2}$, so the normalized duct leakage percentage for this unit is $10 \%$.

\section{Lighting, Water Heating, Appliances}

Capital has a 0.54 EF 50-gallon natural gas water heater.

\section{Retrofit Measures}

The following retrofits were recommended by ORNL.

Table 33: Capital priority list

\begin{tabular}{|l|l|}
\hline \multicolumn{1}{|c|}{ Improvement } & \multicolumn{1}{c|}{ Existing condition } \\
\hline Air sealing & $-0.48 \mathrm{ACH}_{\text {natural }}{ }^{2}$ \\
\hline Insulate and seal crawlspace walls to R-10 & None \\
\hline Insulate walls to R-18 & R-13 \\
\hline Insulate attic floor to R-50 & R-25 \\
\hline Upgrade windows to low-E triple pane & Double-pane vinyl \\
\hline Replace heating system HSPF >9 & 6.80 HSPF \\
\hline Replace cooling system with SEER 16 & 8 SEER \\
\hline New efficient heat pump water heater EF 2.4 & EF 0.54 natural gas \\
\hline Improve lighting with CFL bulbs & $100 \%$ incandescent \\
\hline
\end{tabular}

${ }^{a} \mathrm{ACHnatural}=\mathrm{ACH} 50 / \mathrm{Ncorrected}$, where Ncorrected is the height-corrected LBL "N-factor" (http://www.bpi.org/Web\%20Download/BPI\%20Standards/Building\%20Analyst\%20Professional_228-05nNC-newCO.pdf)

\section{Envelope}

The homeowners sealed and insulated the crawlspace to R-10 using closed cell spray foam.

\section{HVAC}

The homeowners have not upgraded the HVAC units. 


\section{Lighting, Water Heating, Appliances}

The homeowners have not replaced the water heater or appliances per ORNL's recommendations. The homeowners did replace incandescent lighting with CFL and installed a tankless water heating system.

\section{Simulated Energy Savings}

EnergyGauge ${ }^{\circledR}$ software was used to estimate the energy and dollar savings from the installation of the retrofit package. Table 34 shows the estimated energy and energy bill savings and the neutral cash flow for the retrofits. The amortized cost is the yearly payment on a 15-year loan at $7 \%$ interest for the total retrofit cost. The net cost is the yearly loan payment minus the yearly estimated utility cost savings. In the case of Capital, the costs for the retrofits that were completed were estimated from the NREL National Residential Efficiency Measures Database.*

Table 34: EnergyGauge ${ }^{\circledR}$ estimated energy and cost savings for retrofits with neutral cash flow analysis

\begin{tabular}{|c|c|c|c|c|c|c|c|}
\hline & $\begin{array}{l}\text { Site } \\
\text { energy } \\
\text { (MMBtu) }\end{array}$ & $\begin{array}{l}\text { Utility } \\
\text { cost } \\
(\$ / \mathbf{y r})\end{array}$ & $\begin{array}{l}\text { Utility } \\
\text { cost } \\
\text { savings } \\
\text { (\$/yr) }\end{array}$ & $\begin{array}{l}\text { Site } \\
\text { energy } \\
\text { savings } \\
\text { (MMBtu) }\end{array}$ & $\begin{array}{l}\text { Total } \\
\text { Retrofit } \\
\text { cost } \\
(\$)\end{array}$ & $\begin{array}{l}\text { Amortized } \\
\text { cost } \\
(\$ / \mathbf{y r})\end{array}$ & $\begin{array}{l}\text { Net cost } \\
(\$ / y r)\end{array}$ \\
\hline $\begin{array}{l}\text { Pre- } \\
\text { retrofit } \\
\text { house }\end{array}$ & 84.4 & 1,601 & & & & & \\
\hline $\begin{array}{l}\text { Post- } \\
\text { retrofit } \\
\text { house }\end{array}$ & 69.4 & 1,332 & 269 & 15 & 5,302 & 572 & 303 \\
\hline
\end{tabular}

\section{Diagnostics and Test-Out}

Since little work was done on Capital there has been no test-out. However EnergyGauge ${ }^{\circledR}$ can be used to estimate the post-retrofit efficiency of the home based on the work that was completed on Capital. Overall the final HERS index improved from 115 to 97.

\section{Capital Cost and Scope of Work}

The total retrofit cost for Capital was $\$ 5,302$. Table 35 provides a summary of the final scope of work with associated costs.

\footnotetext{
* NREL National Residential Efficiency Measures Database http://www.nrel.gov/ap/retrofits/group_listing.cfm.
} 
Table 35: Capital final scope of work and costs

An asterisk following the cost of a retrofit indicates that this cost is an estimate based on data found at http://www.nrel.gov/ap/retrofits/group_listing.cfm

\begin{tabular}{|c|c|c|c|}
\hline Home characteristics & Pre-retrofit conditions & Retrofit measures & Final costs \\
\hline Foundation & No insulation & $\begin{array}{l}\text { Insulated to R-10 and sealed } \\
\text { crawlspace with foam }\end{array}$ & $\$ 2,600^{*}$ \\
\hline Water heater & Inefficient electric model & Installed tankless system & $\$ 2,500 *$ \\
\hline Lighting & $100 \%$ incandescent & $100 \% \mathrm{CFL}$ & $\$ 202 *$ \\
\hline Total & & & $\$ 5,302$ \\
\hline
\end{tabular}




\section{Celebration Home Profile}

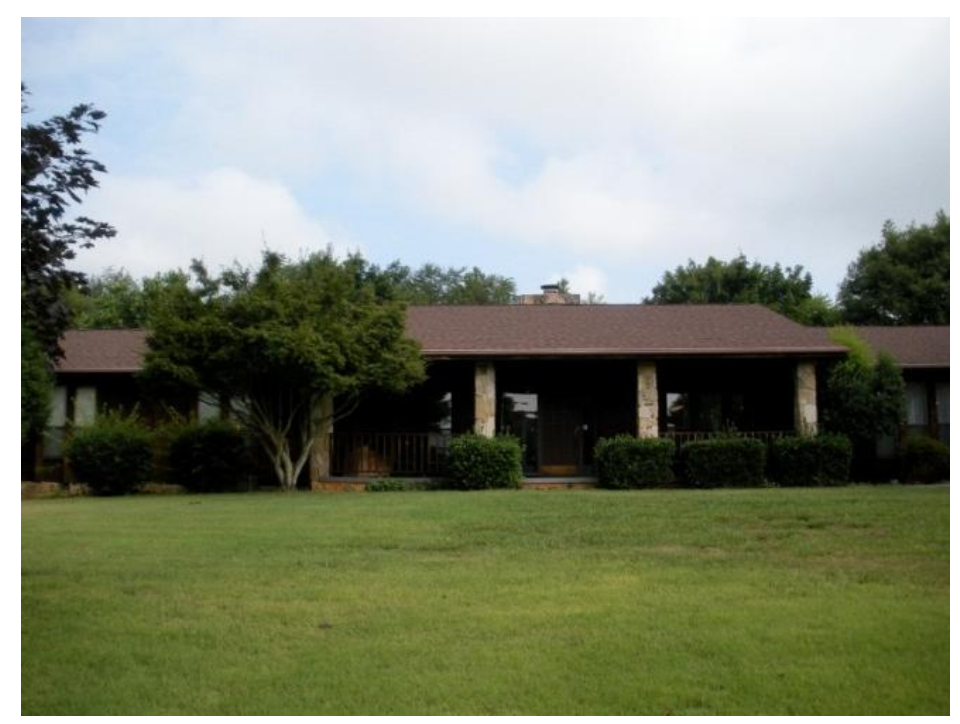

Built in 1978, Celebration is a one-story single-family detached house with 2,884 $\mathrm{ft}^{2}$ of living space. In total, there are three bedrooms and two bathrooms. The home is occupied by two adults and one child. Celebration has a traditional vented attic and vented crawlspace.

The homeowner moved into this home in late 2009. When utility bills were collected, a whole year was not available. Figure 35 shows the utility cost for Celebration. For these 7 months, 80.6 MMBtu of energy was consumed for a total of $\$ 1,425$.

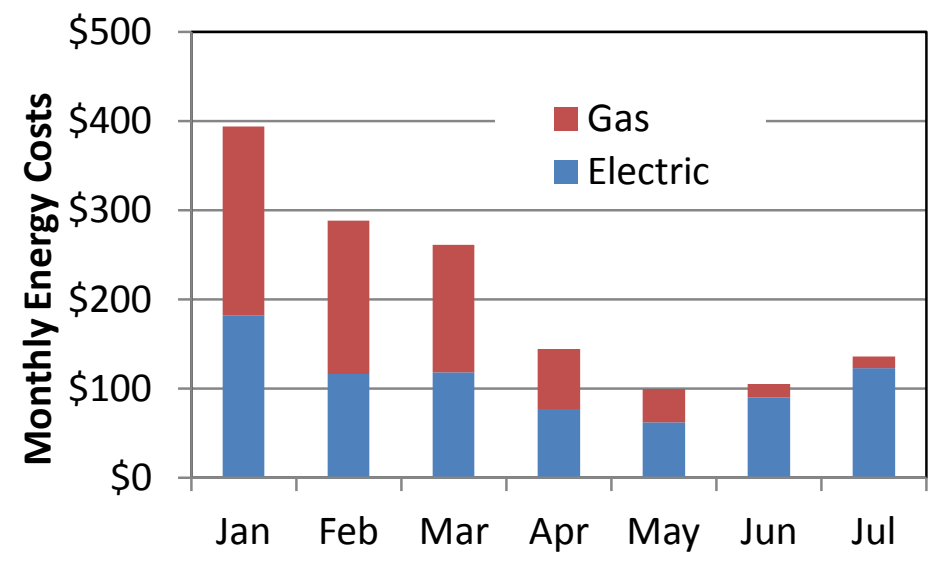

Figure 35: Available utility bills for Celebration. 


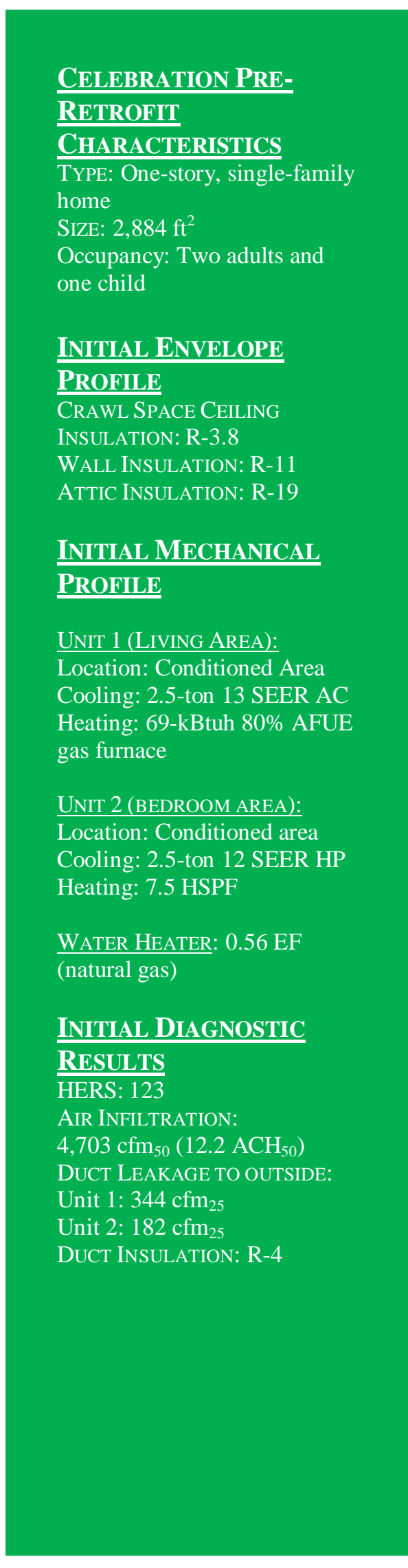

\section{Celebration Pre-Retrofit Condition}

\section{Envelope Profile}

The envelope profile of Celebration is bounded below by a vented crawlspace ceiling with insulation of R-3.8. The exterior walls have an insulation value of $\mathrm{R}-11$, and the vented attic has fiberglass insulation with an insulating value of R-19. Figure 36 shows the envelope profile of Celebration. Figure 37 shows the mechanical closet in the living area with vents leading to the attic area. This was installed to allow combustion air for the gas furnace and water heater located in the closet when the doors of the closet are closed. This is both a dangerous design from a combustion safety standpoint and a bad practice with respect to air infiltration. The crawlspace of Celebration also has moisture issues that need to be addressed.

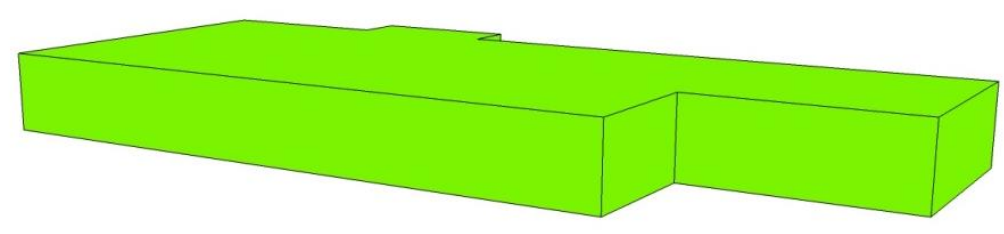

Figure 36: Celebration pre-retrofit envelope profile.

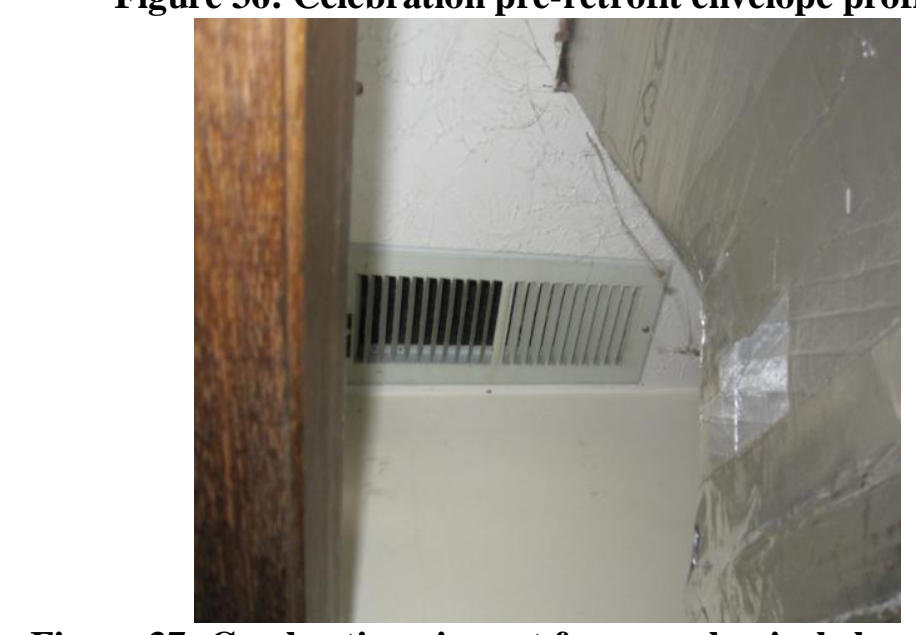

Figure 37: Combustion air vent from mechanical closet leading to vented attic.

The windows in the home are single pane with metal frames.

During the initial home energy assessment, a blower door test was conducted to evaluate the air infiltration. The total air leakage rate was $4,703 \mathrm{cfm}_{50}$. With a conditioned volume of $23,068 \mathrm{ft}^{3}$, the air exchange rate for Celebration was approximately $12.2 \mathrm{ACH}_{50}$. 
HVAC

Celebration has two units. Unit 1 is a 2.5 -ton 13 SEER air conditioner with a $69-\mathrm{kBtuh} 80 \%$ AFUE gas backup. Unit 2 is a 2.5-ton 12 SEER heat pump with 7.5 HSPF. Both units are located in the conditioned space in a mechanical closet in the home. The ducts are run in the attic and crawlspace. Unit 1 services the living area $\left(1,624 \mathrm{ft}^{2}\right)$ of the home, and unit 2 services the bedroom area $\left(1,260 \mathrm{ft}^{2}\right)$ of the home. The total duct leakage to the outside for the living space unit is $344 \mathrm{cfm}_{25}$ and for the bedroom unit is $182 \mathrm{cfm}_{25}$. The duct leakage percentage by floor area is $21 \%$ for the living area duct work and $14 \%$ for the bedroom duct work.

\section{Lighting, Water Heating, Appliances}

Celebration has a $0.56 \mathrm{EF} 40$-gallon natural gas water heater.

\section{Retrofit Measures}

The following retrofits were recommended by ORNL.

Table 36: Celebration priority list

\begin{tabular}{|l|l|}
\hline \multicolumn{1}{|c|}{ Improvement } & \multicolumn{1}{c|}{ Existing condition } \\
\hline Air sealing & $\sim 0.57 \mathrm{ACH}_{\text {natural }}{ }^{2}$ \\
\hline Insulate and seal crawlspace to R-15 & $\mathrm{R}-3.8$ \\
\hline Insulate walls to R-22 & $\mathrm{R}-11$ \\
\hline Insulate attic floor to R-50 & $\mathrm{R}-19$ \\
\hline Upgrade windows to low-E triple pane & Single-pane aluminum frame (30+ years old) \\
\hline Replace heating system with HSPF $>9$ & $80 \%$ AFUE/7.5 HSPF \\
\hline Replace cooling system with SEER 18 & $12-13 \mathrm{SEER}$ \\
\hline New heat pump water heater 2.4 EF & $0.56 \mathrm{EF}$ gas \\
\hline
\end{tabular}

${ }^{a} \mathrm{ACHnatural}=\mathrm{ACH} 50 / \mathrm{Ncorrected}$, where Ncorrected is the height-corrected LBL "N-factor"

(http://www.bpi.org/Web\%20Download/BPI\%20Standards/Building\%20Analyst\%20Professional_2-

28-05nNC-newCO.pdf)

\section{Envelope}

The homeowners have not completed any of the recommended retrofits.

\section{HVAC}

The homeowners have not completed any of the recommended retrofits.

\section{Lighting, Water Heating, Appliances}

The homeowners have not completed any of the recommended retrofits. 


\section{Diagnostics and Test-Out}

Since no work was done on Celebration there has been no test-out. However, speculations using EnergyGauge ${ }^{\circledR}$ on the overall improvement in home efficiency can be made as if the work recommended was completed. Overall, the final HERS index is estimated to improved from 123 to 73 .

\section{Celebration Cost and Scope of Work}

The total retrofit cost for Celebration is estimated to be $\$ 38,228$. Table 37 provides a summary of the final scope of work with associated estimated costs. The costs for the retrofits were taken from the NREL National Residential Efficiency Measures Database. ${ }^{*}$

Table 37: Celebration final scope of work and costs

\begin{tabular}{|c|c|c|c|}
\hline Home characteristics & Pre-retrofit conditions & Retrofit measures & Final costs \\
\hline Foundation & $\mathrm{R}-3.8$ & $\begin{array}{l}\text { Insulate and seal crawlspace } \\
\text { to } \mathrm{R}-15\end{array}$ & $\$ 6,141$ \\
\hline Walls & $\mathrm{R}-11$ & Insulate walls to R-22 & $\$ 7,233$ \\
\hline Windows & $\begin{array}{l}\text { Single pane aluminum } \\
\text { frame }(30+\text { years old })\end{array}$ & $\begin{array}{l}\text { Upgrade windows to low-E } \\
\text { triple pane }\end{array}$ & $\$ 8,868$ \\
\hline Attic/Kneewalls & R-19 & Insulate attic floor to R-50 & $\$ 3,738$ \\
\hline Cooling & 13 SEER & $\begin{array}{l}\text { Replace cooling system with } \\
18 \text { SEER }\end{array}$ & \multirow{2}{*}{$\$ 8,000$} \\
\hline Heating & 80\% AFUE/ 7 HSPF & $\begin{array}{c}\text { Replace heating system with } \\
\text { HSPF }>9\end{array}$ & \\
\hline Water heater & $0.56 \mathrm{EF}$ gas & $\begin{array}{c}\text { New heat pump water heater } \\
2.4 \mathrm{EF}\end{array}$ & $\$ 1500$ \\
\hline Air Infiltration & $11.3 \mathrm{ACH}_{50}$ & Improve to $3 \mathrm{ACH}_{50}$ & $\$ 2,500$ \\
\hline Lighting & $100 \%$ Incandescent & $100 \% \mathrm{CFL}$ & $\$ 248$ \\
\hline Total & & & $\$ 38,228$ \\
\hline
\end{tabular}

\footnotetext{
* NREL National Residential Efficiency Measures Database http://www.nrel.gov/ap/retrofits/group_listing.cfm.
} 


\section{Lessons Learned}

Five homes underwent significant energy retrofits, all of which are estimated to save $35 \%$ or greater due to the energy retrofits that were completed. The other five homeowners decided to complete some or none of the recommended retrofits. Following are some of the lessons learned throughout this early phase of this research project.

\section{Variability in homeowners' willingness to invest in significant energy retrofits}

Half of the homeowners selected for this project decided to postpone some or all of the recommended retrofits because of cost. Based on the homeowner interviews for these five homes, the reasons why all the recommended retrofits were not completed are varied. For example, one homeowner received eight separate bids on his project but felt that all bids were too high. Calling himself cheap, the homeowner declared that he would rather keep the house in its current condition than pay what he considers outrageous fees to contractors. Another homeowner also received many bids but was deterred not by cost but by the divergent opinions of the contractors. The homeowner felt like he needed more similarity of recommendations in order to understand what truly needed improvement at his home. In his own words, he would rather do nothing and know he is wrong than heavily invest in a retrofit and still be wrong. Other households completed only partial retrofits of their homes. One household, for example, only sealed the crawlspace. Their primary motivation was indoor air quality. They noticed significant improvement in air quality after completing this one task, and, pleased with the results, chose to stop there. Another household installed a new HVAC system and some insulation. They invested a sizable sum, but completed only a small portion of the recommendations. With two growing children, cost was a real factor in their decisions. They plan to finish the project in phases.

\section{Utility bill savings are not the primary driver for energy efficiency retrofits}

Cost savings is not the primary driver for homeowners deciding to undergo deep retrofits Some homeowners view a retrofit from a financial perspective, for example, expecting higher potential resale value of the home. However, other homeowners frame their projects in different ways: preparing for retirement, patriotic duty, greener lifestyle, comfort, and health. Several households mentioned using a retrofit to prepare now for lower utility bills during their imminent retirement years. One homeowner continually called home retrofitting the "patriotic duty" of all citizens. He felt he was doing his part to lessen dependence on foreign oil and urged all homeowners to follow his lead. Another homeowner simply wanted to live a greener life. Cost was not an issue for her; she simply wanted to lessen her carbon footprint and help the environment. However, comfort was perhaps the most often mentioned driver for homeowners. Comfort was mentioned by homeowners who installed all recommended measures, who installed some measures, and who chose to install nothing. Lessening draftiness and improving indoor temperature gradient seemed to be among the major concerns of homeowners. Even those homeowners who installed only a few measures noted an increase in comfort inside the home. 


\section{Quality of retrofit work is variable among contractors}

Researchers found that the homeowners who were most involved in the retrofits were most critical of the retrofit work quality. The homeowners of Summit were actively involved in teaching the contractors and crew how to properly cut the structurally insulated sheathing to minimize air gaps between the panels, going as far as making a jig to help the workers achieve straight cuts. The Summit homeowners made the contractors redo work on multiple occasions. Although somewhat frustrated, the homeowners believe that proper education and training of the retrofit workforce would be one of the best investments in the home energy retrofit market. The experience of the Summit homeowners shows that for homeowners who are not actively involved in their project or who have little or no knowledge of how to correctly do energy retrofit work, the quality of the work will vary significantly and depend on the knowledge, training, and pride of work of the contractors and construction crews. The quality of the retrofit work will correlate to energy savings.

\section{Estimated Energy Savings of $30 \%$ and greater can be achieved}

Of the 5 homes that completed the recommended retrofits a total estimated energy savings of 622.8 MMBtu of site energy was estimated due to the retrofits. At a total pre-retrofit energy consumption of $870.1 \mathrm{MMBtu}$, this amounts to an average of $72 \%$ site energy savings per home. This energy savings includes the subtraction of the site generation of the two installed photovoltaic systems from the post-retrofit energy consumption from the utility. Without considering PV, the total energy savings is $581.3 \mathrm{MMBtu}$ which amounts to an average $67 \%$ site energy savings per home.

\section{None of the retrofits are estimated to be cost effective}

The total cost of these retrofits was $\$ 210,798$, or an average of $\$ 42,200$ per home. Without considering PV the total cost was $\$ 163,768$, or an average of $\$ 32,800$ per home. None of the homeowners that underwent energy retrofits saw a neutral or positive cash flow. Assuming a 15 year, $7 \%$ interest loan for the total retrofit costs, the yearly loan payment is greater than the estimated energy bill savings. Even if the homeowner had cash to pay for the retrofits, thus eliminating interest payments, the simple payback it still over 15 years for all homes. It can be noted that $72 \%$ savings is higher than the target $30-50 \%$ energy savings, so maybe we should not expect them to be cost effective. However, the two homes, Baker and Country, with energy savings within this range were still not estimated to be cost effective. 


\section{Summary}

This report documents the selection of ten homeowners for participation in a deep energy retrofit project with the goal of 30-50\% energy savings, the pre- and post-retrofit condition of the homes, the retrofit cost and the estimated energy savings of the retrofits. The homeowners paid for all of the retrofits. Of the ten households selected only five completed all the retrofits recommended by the ORNL research team, three completed some of the recommended retrofits, and two of the households completed none of the recommended retrofits. The selected homes range in age from 20 to 100 years old. The ORNL team recommended retrofits to all homeowners that would save on the order of $30 \%$ or more in energy consumption. EnergyGauge ${ }^{\circledR}$ was used to model the pre- and post-retrofit homes.

Table 38 describes the modeling results and compares them to the pre-retrofit utility bills. Notice that of the three households (shaded green) that completed the recommended retrofits and for which the pre-retrofit mechanical equipment was known, the estimated energy savings range from 35 to 86\%. The two homes (Gaiter and Green) that completed the retrofits, and for which the pre-retrofit mechanical equipment was not known, have estimated energy savings ranging from 79 to $83 \%$. Of the three households (shaded yellow) that completed some of the recommended retrofits, the estimated energy savings is from 3 to $27 \%$. The last two columns of Table 38 show the total retrofit cost and net annual cost of the retrofits completed. The net annual cost is the annual cost of a 15-year loan at $7 \%$ interest for the retrofit cost minus the annual energy bill savings. Notice that none of these retrofits were cost neutral or cost positive for a 15 -year loan at $7 \%$ interest. This and other lessons learned so far from this research is listed below.

- Some homeowners (50\%) are not willing to spend the money to reach $30-50 \%$ energy savings.

- Of the 5 homes that completed the recommended retrofits a total estimated energy savings of $622.8 \mathrm{MMBtu}$ of site energy was saved due to the retrofits. At a total preretrofit energy consumption of $870.1 \mathrm{MMBtu}$, this amounts to an average of $72 \%$ site energy savings per home. This energy savings includes the subtraction of the site generation of the two installed photovoltaic systems from the post-retrofit energy consumption from the utility. Without considering PV, the total energy savings is 581.3 MMBtu which amounts to an average of $67 \%$ site energy savings per home.

- Of the 5 homes that completed the recommended retrofits, the total cost of these retrofits was $\$ 210,798$, or an average of $\$ 42,200$ per home. Without considering PV, the total cost was $\$ 163,768$, or an average of $\$ 32,800$ per home.

- In none of the five homes is the retrofit considered cost-effective, because a 15 year loan at $7 \%$ interest for the retrofit costs results in yearly energy bill savings that are less than the loan payment.

- Quality of retrofit work is significantly variable among contractors, which impacts the potential energy savings of the retrofit. 
- Of the five homes that completed all the recommended retrofits, energy bill savings was not the main driver for energy retrofits.

A final report will present the actual energy savings of the five homes that completed all the recommended retrofits using pre- and post-retrofit utility bills, an analysis of sub-systems such as space conditioning and water heating where appropriate, and insights gained from the final homeowner interviews. The actual energy savings will be used to re-compute the net annual cost described in Table 38.

Table 38: Pre- and post-retrofit model information with neutral cost analysis

\begin{tabular}{|c|c|c|c|c|c|c|c|c|}
\hline & $\begin{array}{c}\text { Actual } \\
\text { Yearly } \\
\text { Site } \\
\text { Energy } \\
\text { (MMBtu) }\end{array}$ & $\begin{array}{c}\text { Pre- } \\
\text { retro site } \\
\text { energy } \\
\text { model } \\
\text { (MMBtu) }\end{array}$ & $\begin{array}{c}\text { Post- } \\
\text { retro site } \\
\text { energy } \\
\text { model } \\
\text { (MMBtu) }\end{array}$ & $\begin{array}{c}\text { Pre-Post } \\
\text { model \% } \\
\text { difference }\end{array}$ & $\begin{array}{c}\text { Pre- } \\
\text { retro } \\
\text { HERS }\end{array}$ & $\begin{array}{c}\text { Post- } \\
\text { retro } \\
\text { HERS }\end{array}$ & $\begin{array}{c}\text { Retrofit } \\
\text { cost } \\
\text { (\$) }\end{array}$ & $\begin{array}{c}\text { Net annual } \\
\text { cost } \boldsymbol{(} \\
\mathbf{( \$ / y r )}\end{array}$ \\
\hline Baker & 128 & 143 & 92.4 & -35 & 119 & 75 & 14,929 & 699 \\
\hline Country & 62 & 74.1 & 40.6 & -45 & 100 & 66 & 23,835 & 1,701 \\
\hline Summit & 126 & 157 & 22 & -86 & 119 & 23 & 86,873 & 7,392 \\
\hline Gaiter & N/A & $279 \boldsymbol{b}$ & 46.8 & -83 & 259 & 75 & 39,699 & 1,454 \\
\hline Green & N/A & $217 \boldsymbol{b}$ & 45.5 & -79 & 186 & 61 & 45,462 & 1,837 \\
\hline Eagle & 226 & N/A & N/A & N/A & 145 & N/A & N/A & N/A \\
\hline Scenic & 163 & 171 & 125 & -27 & 135 & 119 & 12,132 & 1,309 \\
\hline Old Tavern & 232 & 239 & 232 & -3 & 133 & 130 & 1,838 & 93 \\
\hline Capital & 90 & 84 & 69 & -18 & 115 & 97 & 5,302 & 303 \\
\hline Celebration & N/A & N/A & N/A & N/A & 122 & N/A & N/A \\
\hline
\end{tabular}

${ }^{a}$ Annual cost of a 15 -year loan at $7 \%$ interest minus energy bill savings.

${ }^{b}$ The efficiency of the mechanical equipment of the pre-retrofit condition of these two homes were estimated based on: Hendron and Engebrecht, NREL, Building America House Simulation Protocols, Revised October 2010. http://www.nrel.gov/docs/fy11osti/49246.pdf 


\section{Appendix A}

\section{Knoxville News-Sentinel Article (10/29/2009): Homes sought for energy redo —-Larisa Brass}

Jeff Christian is on the hunt for a perfect set of houses in which to demonstrate the ultimate energy home improvement project.

After pouring his energy efficiency know-how into several newly constructed homes throughout the area, the Oak Ridge National Laboratory researcher is setting his sights on existing homes, which represent the lion's share of residential energy usage. Thanks to promised stimulus funds - the final amount hasn't been determined - from the Department of Energy, Christian is beginning to recruit approximately 10 homeowners throughout East Tennessee to participate in a new effort that should improve energy efficiency in these houses 40-50 percent.

The initiative will build off of a project in the Campbell Creek subdivision in Farragut in which ORNL, partnered with TVA, developer Michael Rhodes and local builder John Kerr, provided varied input into construction of three homes typical of new construction across Tennessee. In the first home, built to ENERGY STAR $®$ standards or 15 percent energy savings over new home construction in 2008, Christian observed and documented the construction but could not offer advice or make any efficiency improvements.

In the second home, Christian and fellow researchers worked with builders to put together a package of improvements with a payback period of about 12 years. In the third house, the ORNL engineers employed a more rigorous set of building practices and technologies, including solar power, to produce a home both energy efficient and with the potential to be cost competitive in the near future.

Since the homes have been completed, researchers have been monitoring the houses, in which energy usage is simulated for 2.5 occupants, the U.S. average. So far, the first home is 15 percent more energy efficient than typical construction, the second home is 34 percent more efficient and the third home is 68 percent more efficient.

Now Christian is hoping to help homeowners renovate their existing homes to achieve similar results. However, the project isn't a free ride.

"This is about research," Christian said. "This isn't a giveaway."

The "perfect candidate," Christian said, is a two-story, 2,400-square-foot house that's ripe for energy efficiency improvements including new windows, a new heating and air unit and new appliances. And, homeowners must be willing to invest about $\$ 25,000$ in improvements. The home will be monitored with sensors for one year following the renovation.

In return, homeowners will get a more extensive home audit than provided by TVA, some type of cash incentive still being determined, a discount on state-of-the-art energy efficient appliances and, of course, world-class expertise. 
Those interested in the program should first sign up for a TVA audit through KUB or other distributors.

Christian said he hopes the project will represent a variety of homes in different parts of East Tennessee. He envisions renovating a World War II-era Oak Ridge home or a Victorian house in downtown Knoxville as well as more modern construction. He said the project will establish a benchmark for future energy home improvements.

"We're hoping these 10 grow to 10,000 that wouldn't get done without the insight from this," he said. 


\section{Letter and Questionnaire Sent to Interested Homeowners}

From: Jeff Christian

Date: April 22, 2010

Subject: ORNL Extreme Retrofit Research Project

Happy Earth Day! You had expressed an interest in offering your house for a research project on deep residential retrofit. We need to gather a bit more information to take the next step in the selection process. This letter is being sent to you in hopes you are still interested. This letter will guide you as to the type of information needed at this time.

The project involves analyzing and measuring the before and after energy performance of your energy efficiency retrofit. At the very least you will be upgrading the insulation, air sealing, and HVAC systems in your home - upgrading insulation packages most likely with unvented attics and crawlspaces; sealing band joists and window/door sealing; and upgrading with highefficiency HVAC, windows, appliances, and compact fluorescent lights, etc. We are hoping to find projects that will lead to at least 40 percent energy savings and that the incremental cost for the energy savings features above and beyond replacement cost can be attained with a simple payback of less than 15 years. Each house will be monitored for energy use for an entire year after completion of the retrofit, and a payback analysis performed. Since the goal is to influence TVA's future direction of its "In-home Energy Efficiency Evaluation," the houses we are looking for should be representative of others in the Valley.

It is anticipated that to attain $40 \%$ plus levels of energy savings, you most likely have old heating and air-conditioning systems (SEER of 10 or less) and you have already resolved that you need to replace them. This may also be true for the windows (i.e., seals broken) in your house and maybe even your siding. Know that for reasons other than to save energy is why you need windows. Rarely can new windows attain a 13 year payback based on energy savings. Your heating and air-conditioning ducts most likely are currently in vented attics and crawl spaces. We would like to compare the measured energy usage of the post-retrofit data to our research houses that are controlled by timers to simulate energy use of "average America homes." The first research home is a builder's model, and statistically average for a new home built around 2007 in the Tennessee Valley Authority's service territory. The second model includes the kind of deep retrofits we hope to use in this retrofit project, targeting roughly 40 percent energy savings. I have attached a draft research paper for you to see what we did on this house and think this is a reasonable starting point to consider for your retrofit. We are now in the process of retrofitting this house in a different manner, and some of those technologies will be looked at for recommendation in your house as well. The third home is targeted at zero net energy use in the near future. The first home was insulated with material blown onto the attic floor, above which a cooling and heating unit was located. In the second home, the insulation in the attic floor is replaced with spray foam and other material inserted under the roof and effectively adding the attic and the heating and cooling equipment into the home's conditioned space. All the heating and air-conditioning ductwork is inside the conditioned zone after the retrofit. Another possibility will be to see if we cannot get the ducts inside your existing envelope by hiding them in dropped ceilings and soffits. You may need to have an available vertical chase available or willing to make one in a closet space to make this work. 
Criteria for participation include a willingness and ability to pay for, or get a loan for, the upfront costs of making upgrades after incentives. The homes will have to resemble the statistical averages built in the TVA region.

The house needs to be ready for upgrades to heating, ventilation, and air-conditioning systems, which make up a big share of your home's energy use. Those replacements create a window of opportunity to shift toward more energy efficient models.

Can you provide the following information about your house? This information will only be used to help make the selections.

Are you still interested in participating using your house?

Yes No

When is the earliest time you would be starting this retrofit?

Complete Address

Have you conducted the TVA home audit on the internet? Yes No

Will you be willing to share that report? $\quad$ Yes No

Have you or are you planning on having a TVA in-home evaluation? Yes No

Would you be willing to send us this report? $\quad$ Yes No

Age of your house:

Number of square feet of floor area?

Number of floors:

How do you heat your house? Gas Electricity Wood Propane

Number of heating and air-conditioning systems?

If more than two, what parts of the house are served by each?

Are you currently planning to replace any or all of the following major energy users in your home?

Heating and cooling system 1 ?

Heating and cooling system 2?

$\begin{array}{ccc}\text { Yes } & \text { No } & \text { Age } \\ \text { Yes } & \text { No } & \text { Age } \\ \text { Yes } & \text { No } & \text { Age } \\ \text { Yes } & \text { No } & \text { Age } \\ \text { Yes } & \text { No } & \text { Age } \\ \text { Yes } & \text { No } & \text { Age } \\ \text { Yes } & \text { No } & \text { Age } \\ \text { Yes } & \text { No } & \text { Age }\end{array}$

Windows?

Water heater?

Dryer?

Clothes washer?

Yes No Age

Refrigerator?

Dishwasher? 
Siding or old stucco?

Yes No Age

Please provide the approximate age of each of the above.

Do you have all of your energy bills from the last 2-3 years?

Yes No

If no, will you be willing to request the billing information from

your electricity and gas distributor?

Yes No

Will you be willing to provide us your energy bills?

Yes No

How many people live in your house?

Has the occupancy of your house changed in the last 2 years? If yes how?

Is your house occupancy likely to change in the next year? If yes how?

Are you considering adding a solar photovoltaic system?

Yes No

Are you considering replacing your existing HVAC system with geothermal? $\quad$ Yes No

Estimate Your Homes Energy cost

Total annual energy $=\$$

Annual Electricity (

+ natural gas ( $\mathrm{kWh})$

+ propane ( therms)

+ heating oil (__ gallons $)$

February 2010 electric bill $=\$$

February 2010 gas bill $=\$$

August 2009 electric bill $=\$$

August 2009 gas bill $=\$$

Please return to me by April 28, 2010. If you do not know all the information requested, that is ok; just do the best you can with what you know. Thank you for your interest in this project. Again I will not do anything with the information you provide me other than use it to make the house selections.

Sincerely,

Jeff Christian 



\section{Appendix B}

\section{Homeowner Interview Questions}

\section{Primary Interview}

Introduction: Hello, I'm Amy Wolfe and this is Tim Hendrick. We work in the Environmental Sciences Division at ORNL and want to talk with you today about your participation in the extreme home retrofit program. Specifically, we want to elicit your feedback on the following:

1. How you heard about the retrofit program

2. Why you chose to participate

3. Your expectations

4. Your communications with others

5. Your home's recommendations

6. Your retrofit-related choices

7. Your advice for others

Our goals are to gain a better understanding of the decision-making processes that go into a home retrofit and how homeowners respond to those changes, as well as how to improve the home retrofit process and expand programs like this one to more homes and communities. This interview is voluntary, and you may choose to end it at any time.

So, let's talk about each of these issues separately. (NOTE: Bold questions are main prompts; regular text denotes prompts or follow-on questions.)

\section{Question 1: How did you hear about this program?}

- What first attracted you to it?

\section{Question 2: What convinced you to participate in this program?}

- What is your main motivation? (possible prompts: energy efficiency, technology, demonstrating leadership, saving money down the road, increased comfort, better re-sale value, "free advice," etc.)

- What were your major considerations about participating in the program?

- What pushed you toward [or away] from the program?

- Did you consult with anyone before making your final decision? Who?

Question 3: What are your expectations from the retrofit (process; outcomes)?

- Main positive expectations?

- Any negative expectations?

Question 4: To what extent have you discussed your retrofit plans (or this program)? 
- With family?

- Neighbors?

- Friends?

- Coworkers?

\section{Question 5: What were your impressions of the recommendations you received?}

- In what order did you receive your recommendations? (TVA,ORNL)

- How useful were the recommendations you received?

- What would have made them more useful?

Question 6: Why did you choose these measures? (Give them a sheet highlighting their selections from the full list of recommendations. If homeowners have not yet made choices, give homeowners a sheet with the full list of recommendations for their home.)

What is your current thinking about which retrofit measures you will select?

- Which measures are you implementing?

○ Yourself?

○ Via contractors?

$\circ$ In what sequence?

- Why? To what extent was this decision influenced by the sequence suggested in the audits?

- If they choose not to adopt some recommendation: Why did you decide against [the specific measure(s)]?

- Possible follow-ups: To what extent did up-front cost; financing; bang-for-the buck; potential household disruption; fixed vs. active (that homeowner had to deal with) measures; familiar vs. unproven technologies; aesthetics; etc., affect your decision?

- Were there conflicting recommendations? (If yes, ask who they chose to follow and why)

Question 7: What advice do you have for other homeowners who may be considering a retrofit?

- For utilities like TVA?

- For governmental and non-governmental organizations wishing to promote deep home retrofits (in general and in neighborhoods)?

- For contractors who may be installing the measures? 


\section{Second Interview}

Introduction: Hello once again. I'm Amy Wolfe and this is Tim Hendrick. We want to talk with you again today about the retrofit process happening in your home. Specifically, we want to find out about the following:

1. The status of your project

2. The installation process

3. Any differences the retrofits have made

4. Advice you may have for other homeowners

Our goal is to gain a better understanding of the retrofit process, how it affects homeowners, and how it may be improved.

Let's talk further about each of these issues.

Item 1: What is the status of your project? (Give them the sheet from the first interview with their recommendations and discuss each item)

Item 2: Describe the overall installation process (For the third interview, inquire about installation of any measures in the time period between interviews.)

- Possible prompts - length of time, effectiveness/reliability of contractors, extent of disruption, costs, or "surprises"?

- To what extent did/has the installation process met your expectations? To what extent $\mathrm{did} /$ has the installation process not met your expectations?

- Smoothest aspects? Biggest frustrations?

- To what extent did you deviate from your original retrofit plan (refer to sheet from first interview)? If deviation, why?

- What advice do you have for other homeowners facing similar retrofit installation processes?

- What advice do you have for contractors conducting these sorts of retrofits (to make the process more marketable for the contractors; more appealing to homeowners)?

\section{Item 3: How have the retrofits worked?}

- To what extent have they met your expectations? (possible prompts: energy efficiency, technology, demonstrating leadership, saving money down the road, increased comfort, better re-sale value, "free advice," and with regard to costs, operation, and maintenance)

- What, if any, benefits arose that you did not anticipate?

- What, if any, negative effects arose that you did not anticipate?

- To what extent have the retrofits changed your (and household members') behavior?

o Possible prompts: check meters (and, what do you do after you check meters); set thermostats or other equipment differently; clean/change filters more often; use different filters; etc.

- To what extent have the retrofits changed how you maintain your home (and equipment)? 
O To what extent have the retrofits affected your behavior in other ways (e.g., outside your home - water usage; how/what you drive; behavior at work; etc.).

○ To what extent have you communicated about the retrofits with others (family, friends, neighbors, co-workers, etc.)?

- Have you undertaken any further retrofit work beyond the recommendations? (If yes, what? If no, do you plan to in the near term?)

Item 4: Advice (in addition to questions associated with Item 2): Based on your experiences with the retrofits to date, what advice do you have for other homeowners who may be considering a retrofit?

- Looking back, what would you do differently?

- Advice for utilities like TVA?

- Advice for governmental and non-governmental organizations wishing to promote deep home retrofits (in general, and in neighborhoods)? 


\section{Third Interview}

Introduction: Hello again. I'm Amy Wolfe and this is Tim Hendrick. We want to talk with you today about life in your home after the retrofit was completed. Specifically, we want to know about the following:

1. Your responses to the new systems installed

2. Changes to your daily life

3. Advice you may have for others

Our goal is to gain understanding of how homeowners adjust to life in a retrofitted home and analyze how that process may be simplified in the future, making retrofits more marketable.

Let's talk more about each of these issues.

\section{Issue 1: Responses to installed systems}

- What were your expectations of life after the retrofit?

- To what extent has the retrofit met your expectations?

- What levels of energy savings have you noticed?

- How well are the new systems performing?

- To what extent are you using the systems in the manner you were instructed?

\section{Issue 2: Changes to daily life}

- What changes in routine have been caused by the retrofit? (ask about positive and negative changes)

- Has living in a retrofitted home caused you to modify your life in other ways?

- Have you done any work beyond the initial recommendations? (If yes, what? If not, do you plan to?)

- To what extent have you discussed life in the retrofitted house with friends?

- Family?

- Neighbors?

- Coworkers?

\section{Issue 3: Advice for others}

- How can the process of adjusting to life in a retrofitted home be simplified for other homeowners?

- Would the endorsement of a utility provider or municipal government have affected your decision to perform a retrofit?

- To what extent should retrofits be performed in your neighborhood? 
